ANDRESSA DE OLIVEIRA DIAS BORGES

\title{
ANÁLISE DE POPULAÇÕES LEUCOCITÁRIAS EM DOADORES DE PLAQUETAS E EM CÂMARA DE LEUCORREDUÇÃO
}

Dissertação apresentada ao Programa de PósGraduação em Imunologia do Instituto de Ciências Biomédicas da Universidade de São Paulo, para obtenção do Título de Mestre em Ciências. 


\section{ANDRESSA DE OLIVEIRA DIAS BORGES}

\section{ANÁLISE DE POPULAÇÕES LEUCOCITÁRIAS EM DOADORES DE PLAQUETA E EM CÂMARA DE LEUCORREDUÇÃO}

Dissertação apresentada ao Programa de PósGraduação em Imunologia do Instituto de Ciências Biomédicas da Universidade de São Paulo para obtenção do Título de Mestre em Ciências.

Área de concentração: Imunologia

Orientador: Dr. Luiz Roberto Sardinha

Versão corrigida. A versão original eletrônica se encontra-se disponível tanto na Biblioteca do ICB quanto na Biblioteca Digital de Teses e Dissertações da USP (BDTD). 
DADOS DE CATALOGAÇÅ NA PUBLICAÇÅ (CIP)

Serviço de Biblioteca e Informaçăo Biomédica do

Instituto de Ciências Biomédicas da Universidade de Säo Paulo

Q reproduçăto tota

Borges, Andressa de Oliveira Dias.

Análise de populações leucocitánias em doadores de plaquetas e em

câmara de leucorreduçäo / Andressa de Oliveira Dias Borges. -- Säo

Paulo, 2014.

Orientador: Prof. Dr. Luiz Roberto Sardinha.

Dissertação (Mestrado) - Universidade de São Paulo. Instituto de

Ciências Biomédicas. Departamento de Imunologia. Área de

concentração: Imunologia. Linha de pesquisa: Imunologia celular humana.

Versão do título para o inglês: Analysis of leukocyte populations in platelet donor and in leukoretuction system chamber.

1. Câmara de leucorredução 2. Linfócitos 3. Células mononucleares de sangue 4. Citometria de fluxo 5. Aférese 6. Ativação dos

linfócitos I. Sardinha, Prof. Dr. Luiz Roberto II. Universidade de São

Paulo. Instituto de Ciếncias Biomédicas. Programa de Pós-Graduação em Imunologia III. Título. 
Candidato(a): $\quad$ Andressa de Oliveira Dias Borges.

Título da Dissertação: $\quad$ Análise de populações leucocitárias em doadores de plaquetas e em câmara de leucorredução.

Orientador(a): $\quad$ Prof. Dr. Luiz Roberto Sardinha.

A Comissão Julgadora dos trabalhos de Defesa da Dissertação de Mestrado, em sessão pública realizada a ..................., considerou
( ) Aprovado(a)
( ) Reprovado(a)

Examinador(a): Assinatura:

Nome:

Instituição:

Examinador(a): Assinatura:

Nome:

Instituição:

Presidente: Assinatura:

Nome:

Instituição: 
São Paulo, 28 de novembro de 2012.

\section{PARECER 1087/CEP}

A Comissão de Ética em Pesquisas em Seres Humanos do ICB, na sessão realizada no dia 22.11.2012, APROVOU o projeto intitulado: "Análise das Populações Leucocitárias em Doadores Frequentes de Plaquetas e em Câmaras de Leuco-redução", dos autores Luiz Roberto Sardinha e a aluna Andressa de Oliveira Dias Borges.

Cabe aos Pesquisadores executantes elaborar e apresentar a este Comitê, relatórios anuais (parciais ou final ), de acordo com a resolução 196/06 do Conselho Nacional da Saúde, item IX. 2 letra c.

O primeiro relatório deverá ser encaminhado à Secretaria deste CEP em 22.11.2013.

Atenciosamente,

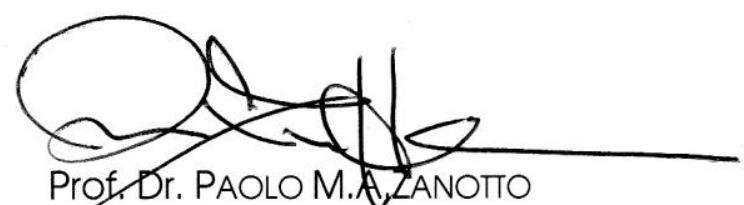

Prof, Dr. PAOLO M.AZZANOTO

Coordenador da Comissão de Ética em

Pesquisas com Seres Humanos - ICB/USP 


\section{INSTITUTO DE CIÊNCIAS BIOMÉDICAS DA UNIVERSIDADE DE SÃO}

\section{parasome}

\section{PARECER CONSUBSTANCIADO DO CEP}

\section{DADOS DO PROJETO DE PESQUISA}

Título da Pesquisa: Análise das Populações Leucocitárias em Doadores Frequentes de Plaquetas e em Câmaras de Leuco-redução.

Pesquisador: Luiz Roberto Sardinha

Área Temática:

Versão: 1

CAAE: 07136512.1 .1001 .5467

Instituição Proponente: Universidade de São Paulo ((INSTITUTO DE CIENCIAS BIOMEDICAS))

\section{DADOS DO PARECER}

Número do Parecer: 155.639

Data da Relatoria: 22/11/2012

\section{Apresentação do Projeto:}

Análise das Populações Leucocitárias em Doadores Frequentes de Plaquetas e em Câmaras de Leucoredução

\section{Objetivo da Pesquisa:}

O projeto tem como objetivo comparar algumas populações celulares presentes no sangue periférico entre doadores de primeira vez ou doadores frequentes de plaquetas pelo metodo de aférese. Além disso, 0 projeto visa avaliar a viabilidade das células descartadas após a doação no Leuko Reduction System.

\section{Avaliação dos Riscos e Benefícios:}

De acordo com os resultados esperados, os proponentes evidenciam que um dos benefícios é ratificar de que a doação frequente de plaquetas não acarreta e riscos para o doador. Além disso, e mais importante, os pesquisadores apontam para o fato de que existe a possibilidade de utilização dos leucócitos que são descartados pelo método de leuco reduction. Tal possibilidade proporcionaria não só a facilitação da obtenção de células viáveis a serem utilizadas em pesquisa, como também reduzir o número de punções nesses indivíduos.

\section{Comentários e Considerações sobre a Pesquisa:}

Sumário do projeto

O pesquisador propõe avaliar possiveis alterações presentes em populações celulares de sangue periferico de indivíduos voluntários a doação de plaquetas. Para isto, os mesmos utilizarão 


\section{INSTITUTO DE CIÊNCIAS BIOMÉDICAS DA UNIVERSIDADE DE SÃO}



amostras de doadores que doam pela primeira vez e outros que doaram 15 ou mais vezes, considerados doadores frequentes. Após a obtenção das amostras, celulas mononucleares serão obtidas por gradiente de percoll, e submitadas a marcação para citometria de fluxo. Serão avaliadas populações como linfócitos $T$ (CD4, CD8), Linfocitos B (CD19), células NK (CD56) e monócitos (CD14) assim como marcadores de ativação como CD25, CD45, CD45RA, CD45RO, CD69, CD122 e CD34. O projeto visa, não só avaliar possiveis diferenças nessas populações celulares, como tambem comprovar a viabilidade de leucócitos que são descartados após a obtenção das plaquestas pela câmara de leucoredução

\section{Considerações sobre os Termos de apresentação obrigatória:}

O TCLE esta adequado à proposta. O mesmo apresenta um português claro e pouco rebuscado, sendo de facil entendimento para os doadores

\section{Recomendações:}

Sem recomendações.

\section{Conclusões ou Pendências e Lista de Inadequações:}

O proponente apresenta uma proposta clara e objetiva, sendo que considero o mesmo aprovado para sua realização

\section{Situação do Parecer:}

Aprovado

\section{Necessita Apreciação da CONEP:}

Não

\section{Considerações Finais a critério do CEP:}

Cabe aos pesquisadores executantes elaborar e apresentar a este comitê relatórios anuais (parciais ou final) de acordo com a resolução 196/96 conselho Nacional da Saúde, ítem IX.2 letra c. Em não havendo um biorepositório e se houver retenção de material deverá ser solicitado o devido cadastro conforme modelo constante site do ICB.

Endereço: Av. Prof ${ }^{\circ}$ Lineu Prestes, 2415

Bairro: UF: SP

Telefone: (113)091--7733
CEP: $\quad 05.508-000$

$$
\text { Fax: (113)091--8405_E-mail: pzanotto@usp.br; cep@icb.usp.br }
$$


INSTITUTO DE CIÊNCIAS

BIOMÉDICAS DA

UNIVERSIDADE DE SÃO

QRintogforma

27 de Novembrode 2012

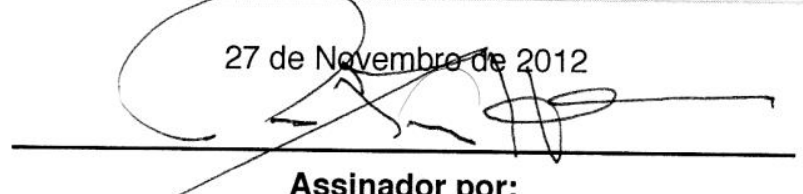

Paolo Marinho de Andrade Zanotto

(Coordenador)

Endereço: Av. Prof ${ }^{\circ}$ Lineu Prestes, 2415 


\section{HOSPITAL ISRAELITA ALBERT EINSTEIN-SP}

\section{PARECER CONSUBSTANCIADO DO CEP}

\section{DADOS DO PROJETO DE PESQUISA}

Título da Pesquisa: Análise das Populações Leucocitárias em Doadores Frequentes de Plaquetas e em Câmaras de Leuco-redução.

Pesquisador: Luiz Roberto Sardinha

Área Temática:

Versão: 1

CAAE: 07136512.1.2002.0071

Instituição Proponente: Hospital Israelita Albert Einstein-SP

\section{DADOS DO PARECER}

Número do Parecer: 181.287

Data da Relatoria: 19/12/2012

\section{Apresentação do Projeto:}

A doação de sangue é a única forma de obter hemocomponentes como glóbulos vermelhos, glóbulos brancos e plasma, necessários para diversos procedimentos médicos. Para obtenção de plaquetas em quantidade suficiente para procedimentos terapêuticos são necessárias várias bolsas de sangue ou a retirada seletiva de grande quantidade de plaquetas de um mesmo doador sem a retirada de outros componentes sanguineos (plaquetaférese), atualmente este processo é automatizado e combina uma série de técnicas como separação por centrifugação e elutriação para obtenção de plaquetas com alto grau de pureza, este processo gera um subproduto que é a câmara de leuco-redução, esta câmara é descartada ao final do processo contendo em seu interior grande quantidade de leucócitos viáveis para utilização em pesquisa cientifica.Atualmente são permitidas até 24 doações de plaquetas anuais por um mesmo indivíduo, pouco se fala sobre a possibilidade de leucopenia nos doadores frequentes de plaquetas por aférese, porém não existem estudos na literatura descrevendo os efeitos de seguidas doações de plaquetas nas células sanguíneas dos doadores.

Objetivo da Pesquisa:

Objetivo Primário:

Avaliar e comparar as populações celulares no sangue em doadores de primeira vez e doadores frequentes de plaquetas por aférese.

Objetivo Secundário:

Avaliar a viabilidade do uso das células descartadas no na Câmara de leuco-reduçao (Leuko

Endereço: Av. Albert Einstein 627 - 2ss

Bairro: Morumbi CEP: $05.652-000$

UF: SP Município: SAOPAULO

Telefone: (11)2151-3729 Fax: (11)2151-0273 E-mail: cep@einstein.br 


\section{HOSPITAL ISRAELITA ALBERT EINSTEIN-SP}

Reduction System - LRS) durante procedimento de doação de plaquetas por aférese para pesquisas científicas, avaliando:- Tipos celulares presentes na câmara.- Similaridade da distribuição das diferentes populações celulares entre o sangue e a câmara.- Marcadores de ativação linfocitária e capacidade proliferativa.- Presença de célulastronco

hematopoiéticas e viabilidade de isolamento e cultivo in vitro.

\section{Avaliação dos Riscos e Benefícios:}

Riscos:

O presente trabalho apresenta risco mínimo aos voluntários envolvidos. Do sangue venoso, serão coletados de 10 a $20 \mathrm{ml}$, quantidade que não oferece risco ao doador. Para coleta do material, será utilizado o mesmo acesso para a realização da aférese, assim, o indivíduo não passará por nenhum procedimento adicional.A utilização da câmara de leuco-redução também não causa nenhum ônus ao doador, uma vez que é um subproduto da doação de plaquetas.

Benefícios:

O presente trabalho apresenta risco minimo aos voluntários envolvidos.Do sangue venoso, serão coletados de 10 a $20 \mathrm{ml}$, quantidade que não oferece risco ao doador. Para coleta do material será utilizado o mesmo acesso para a realização da aférese, e pelo qual é retirada a amostra de sangue para a realização dos testes laboratoriais, assim, $\mathrm{O}$ indivíduo não passará por nenhum procedimento adicional.A utilização da câmara de

leuco-redução também não causa nenhum ônus ao doador, uma vez que é um subproduto da doação de plaquetas.

\section{Comentários e Considerações sobre a Pesquisa:}

O presente estudo será realizado no Laboratório de Pesquisa Experimental do Hospital Albert Einstein. Será utilizada a câmara LRS de doadores de plaquetas voluntários, bem como uma aliquota com $10 \mathrm{~mL}$ de sangue venoso, desses doadores, para comparação da proporção de células presentes na câmara LRS e no sangue. As amostras serão colhidas no Banco de Sangue do Hospital Albert Einstein. Todas as amostras serão obtidas com autorização dos participantes mediante assinatura do Termo de Consentimento Livre Esclarecido. Para inclusão no grupo de doadores frequentes de plaquetas serão considerados indivíduos que tenham realizado pelo menos 15 doações de plaquetas por ano nos últimos dois anos. Como controles, amostras coletadas de indivíduos que estejam realizando a primeira doação.

\section{Considerações sobre os Termos de apresentação obrigatória:}

O TCLE está de acordo com a resolução n 196/96 do CNS/MS.

\section{Recomendações:}

Nâo há.

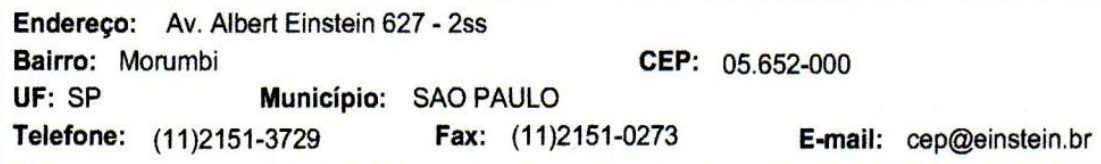




\section{HOSPITAL ISRAELITA ALBERT EINSTEIN-SP}

Conclusões ou Pendências e Lista de Inadequações:

Sem inadequações ou pendências

Situação do Parecer:

Aprovado

Necessita Apreciação da CONEP:

Não

Considerações Finais a critério do CEP:

Acatado pelo colegiado o parecer do relator.

SAO PAULO, 26 de Dezembro de 2012

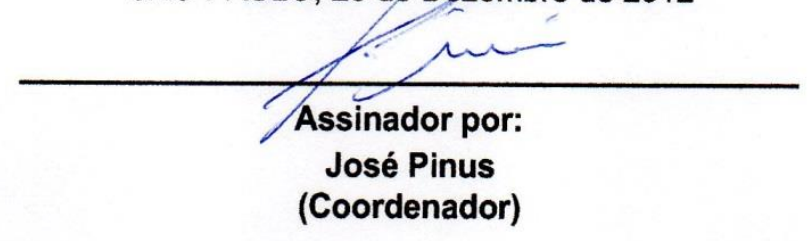

Endereço: Av. Albert Einstein 627 - 2ss

CEP: $05.652-000$

UF: SP Município: SAO PAULO

Telefone: (11)2151-3729 Fax: (11)2151-0273 E-mail: cep@einstein.br 
À Deus dedico meu trabalho e minha vida. 


\section{AGRADECIMENTOS}

Agradeço em primeiro lugar a Deus, que me guiou até aqui, que me mostrou o caminho, que me deu forças quando mais precisava e me deu sabedoria e inteligência durante todas as etapas desse projeto.

Ao meu amado esposo Joel, que me apoiou em uma jornada incerta, mas que culminou na realização desse desejo tão especial. Agradeço por me incentivar a ir atrás dos meus sonhos. Por me apoiar. Por secar minhas lágrimas. Por me lembrar de que sempre há uma saída. Agradeço por abrir mão dos seus sonhos para que eu pudesse realizar os meus. Sem essa pessoa tão especial nada disso seria possível.

Agradeço aos meus pais, por todo apoio e por serem a base de toda minha vida. Obrigada por todos os sacrifícios que fizeram por seus filhos. Aos meus queridos irmãos que ajudaram a moldar a pessoa que sou hoje.

Ao meu orientador Luiz Roberto Sardinha que se arriscou em ajudar uma bióloga enferrujada e que estava há muito tempo longe de um laboratório e de uma bancada, que nem sabia o que era imunologia direito, que dirá um citômetro! Agradeço por aceitar fazer essa jornada comigo. Muita obrigada pela paciência, que foi muita mesmo, pelos ensinamentos, pelas risadas e também pelas broncas. Sem a sua parceria esse trabalho não se concretizaria.

Agradeço a todo grupo de pesquisa que me recebeu muito bem e de braços abertos. Muito obrigada Dr. Luiz Vicente Rizzo, Dra. Anna Carla Goldberg e Dra. Karina Salmazi por todas as discussões científicas e desenvolvimento do trabalho.

Estou muito feliz pelos amigos que encontrei; amigos que vão ficar para sempre em meu coração. Carina, sempre disposta a encarar um chocolate comigo; Eliana e Pedro, quantos conselhos! Ana Eduarda, que ficou com a pior parte: me aguentar na fase final do trabalho. E também aqueles que de uma forma ou de outra estiveram comigo: Renata, Suzana, Giovana, Deise, Sheyla, Santiago, Karen. Vocês são muito queridos e especiais e com certeza fazem parte dessa realização. Sem o companheirismo de vocês essa jornada teria sido bem mais difícil. Muito obrigada!!!

A todos os queridos companheiros da Pesquisa Experimental do Instituto de Ensino e Pesquisa do Hospital Albert Einstein. Alunos e funcionário que de um jeito ou de outro 
estiveram comigo durante toda minha trajetória. Queridos que ainda estão no laboratório ou que já saíram: agradeço por tudo.

A equipe de estatística do Hospital Albert Einstein que sempre esteve disponível para discussão dos dados e para ajudar nas dúvidas.

Em especial agradeço a toda equipe do Banco de Sangue do Hospital Albert Einstein que, com muita prontidão, cortesia e simpatia, atenderam aos meus pedidos de amostras; a Dra. Araci Massami Sakashita pela colaboração; mas em especial agradeço a toda equipe de enfermagem que tornou a realização desse trabalho possível.

A todos os professores do departamento de Imunologia por todo conhecimento transmitido e pelo empenho em desenvolver pensamento crítico. Obrigada por me ensinarem a amar imunologia. Agradeço também a todos os funcionários que sempre estiveram dispostos a ajudar.

Em especial agradeço aos professores Dr. Jean Pierre, Dr. Alexandre Barbuto e Dra. Karina Salmazi, que através de conselhos, ideias e sugestões, na ocasião da qualificação, ajudaram na conclusão da dissertação. Muito obrigada por disporem de tempo, paciência e por enriquecerem meu conhecimento científico, seja na ocasião citada ou em outros momentos.

Aos amigos que encontrei nesse departamento, todos estarão sempre em meu coração.

Agradeço ao IEP, UNIEMP e CNPq pelo apoio financeiro. 
"Quanto mais eu estudo a natureza mais fico impressionado com a obra do Criador. Nas menores de suas criaturas Deus colocou propriedades extraordinárias...".

Louis Pasteur 


\section{RESUMO}

Dias-Borges AO. Análise de populações leucocitárias em doadores de plaquetas e em Câmara de Leucorredução. [dissertação (Mestrado em Imunologia)]. São Paulo: Instituto de Ciências Biomédicas, Universidade de São Paulo; 2014.

A doação de plaquetas por aférese é um procedimento automatizado que permite a obtenção deste hemocomponente em grande quantidade e com alto grau de pureza; deste processo obtém-se um subproduto chamado Câmara de Leucorredução (CLR) que é descartado ao final da doação. São permitidas até 24 doações/ano; porém as possíveis consequências de doações frequentes para esses doadores são pouco investigadas. Assim, foram identificados e quantificados os leucócitos de doadores de plaquetas frequentes e de 1a vez. Também foi avaliada a viabilidade do uso das células mononucleares da CLR para pesquisas. Observou-se mais células na CLR que no sangue e que a frequência das populações estudadas foi similar em ambas às amostras. O estado de ativação e a capacidade funcional (proliferação e produção de citocinas) foram similares entre CLR e sangue, assim como a taxa de apoptose espontânea. Entre doadores frequentes e de primeira vez não houve diferença no número de leucócitos, sugerindo que doações recorrentes não alteraram as populações leucocitárias.

Palavras-chave: Câmara de Leucorredução (CLR). Leucócitos. Doadores de plaquetas. Aférese. Células mononucleares. Ativação de linfócitos. Imunofenotipagem de leucócitos. Citometria de fluxo. 


\begin{abstract}
Dias-Borges AO. Analysis of leukocyte populations in platelet donor and in Leukoretuction System Chamber. Dissertation (Master Immunology). São Paulo: Instituto de Ciências Biomédicas, Universidade de São Paulo; 2014.

Plateletpheresis is an automatized procedure to obtain high purity platelet for transfusions. From this procedure it's possible to obtain a byproduct: The Leukoreduction System Chamber (LRSC), which is discarded at the end of donation process. This type of donation allows 24 donation/year, but the consequences of frequent donations are poorly investigated. Therefore, we identified and quantified leukocytes of frequent and first time platelet donor. Also, was evaluated the viability, for research, of mononuclear cells recovery from LRSC. The total number of mononuclear cells was higher in LRSC than in peripheral blood samples, but the frequencies were similar in both the samples. Activation state and functional capacity (measured by cell proliferation and cytokine production) were similar in both, blood and LRSC mononuclear cells, as well as spontaneous apoptosis. Among frequent (6 or more donations in 1 year) and first time donor, there was no difference in the leukocyte total number, suggesting that frequent donation do not modify these cells.
\end{abstract}

Keywords: Leukoreduction system chamber (LRSC). Platelet donation. Apheresis. Peripheral blood mononuclear cells (PBMC). Leukocytes. Lymphocyte Activation. Leukocyte phenotiping; Flow Cytometry. 


\section{LISTA DE FIGURAS}

Figura 1 - Processo de separação automatizada das plaquetas. .36

Figura 2 - Câmara de Leucorredução 36

Figura 3 - Estratégias para caracterização das populações leucocitárias a partir da utilização do marcador de linhagem hematopoiética CD45 (A-C) e na ausência do mesmo (D-F)

Figura 4 - Caracterização dos linfócitos T.

Figura 5 - Caracterização de linfócitos B.

Figura 6 - Caracterização de monócitos e células NK.

Figura 7 - Estratégia para identificação e análise da expressão do marcador precoce de ativação CD69 em linfócitos T e B.

Figura 8 - Estratégia para análise da expressão do receptor de IL-2 (CD122 e CD25) em linfócitos T.

Figura 9 - Estratégia para análise da expressão de CD45RA e CD45RO em linfócitos T .52

Figura 10 - Estratégia de identificação de linfócitos T e B apoptóticas (Anexina- $\mathrm{V}^{+}$) .54

Figura 11 - Caracterização das Células-tronco hematopoéticas (CTH) $\left(\mathrm{CD} 34^{+} \mathrm{CD} 45^{\text {low }}\right) \ldots . . . . . .56$

Figura 12 - Comparação do rendimento celular/mL entre amostras de Sangue e CLR. .61

Figura 13 - Análise individual da frequência e relação da população de linfócitos presentes em amostras de sangue o CLR.

Figura 14 - Análise individual da frequência e relação da população de linfócitos T presentes em amostras de sangue o CLR.

Figura 15 - Comparação da frequência de $T C D 4^{+}$e $T C D 8^{+}$entre amostras de sangue e da CLR

Figura 16 - Análise individual da frequência de linfócitos B presentes em amostras de sangue o CLR.

Figura 17 - Análise individual da frequência de monócitos $\left(C D 3^{-} \mathrm{CD} 14^{+}\right)$presentes em amostras de sangue e da CLR. 
Figura 18 - Análise da frequência de células $\mathrm{NK}\left(\mathrm{CD} 3^{-} \mathrm{CD} 56^{+}\right)$presentes em amostras de sangue o CLR de mesmos indivíduos.

Figura 19 - Análise individual da frequência de células NK $\left(\mathrm{CD}^{-} \mathrm{CD}^{5} 6^{+}\right)$presentes em amostras de sangue e da CLR.

Figura 20: Análise comparativa da expressão de CD69 em linfócitos T e B em amostras de sangue e de CLR.

Figura 21 - Análise individual da relação da expressão de CD69 em linfócitos T CD4 ${ }^{+}$; T CD8 ${ }^{+}$e Linfócitos B em amostra de sangue e da CLR.

Figura 22 - Análise comparativa da expressão das cadeias alfa (CD25) e beta (CD122) do receptor de alta afinidade para $\mathrm{IL}-2$ em linfócitos $\mathrm{T} \mathrm{CD}^{+}$e $\mathrm{T} \mathrm{CD8}{ }^{+}$.

Figura 23: Análise da expressão de CD45RA e CD45RO em populações de linfócitos T $C D 4^{+}$e $\mathrm{TCD}^{+}$em amostras de sangue e da CLR.

Figura 24 - Análise individual da correlação da expressão de CD45RA e CD45RO em linfócitos T CD4 e T CD8 em amostra de sangue e CLR.

Figura 25 - Análise proliferativa de linfócitos $\mathrm{T} \mathrm{CD4}^{+}$de amostras de sangue e de $\mathrm{CLR}$, de mesmo indivíduo, frente a quantidades diferentes de PHA. .76

Figura 26 - Análise individual da correlação da expressão da proliferação de linfócitos T CD4 ${ }^{+}$ em amostra de sangue e da CLR.

Figura 27 - Análise individual proliferativa de linfócitos $\mathrm{T} \mathrm{CD8}^{+}$de amostras de sangue e de CLR frente a quantidades diferentes de PHA.

Figura 28 - Análise individual da correlação da expressão da proliferação de linfócitos T CD8 ${ }^{+}$ em amostra de sangue e da CLR.

Figura 29 - Produção de citocinas de amostras do sangue e da CLR .80

Figura 30 - Análise da apoptose espontânea em linfócitos T CD4, T CD8 e linfócitos B.

Figura 31 - Análise individual da frequência e do rendimento de células-tronco hematopoéticas (CD34 $\left.4^{+} \mathrm{CD} 45^{\text {low }}\right)$ presentes em amostras de sangue e da CLR.

Figura 32 - Análise comparativa dos leucócitos e suas principais populações em doadores de plaquetas frequentes e de primeira vez. 
Figura 33 - Análise comparativa de linfócitos recuperados, por gradiente de densidade (Ficoll), de amostras de sangue e da CLR de doadores frequentes e de 1 a vez

Figura 34 - Análise comparativa de linfócitos T recuperados, por gradiente de densidade (Ficoll), de amostras de sangue e da CLR de doadores frequentes e de 1avez. .86

Figura 35 - Análise comparativa de linfócitos $\mathrm{B}$, monócitos, células $\mathrm{NK}$ e Células $\mathrm{CD} 3^{+} \mathrm{CD} 56^{+}$ recuperados, por gradiente de densidade (Ficoll), de amostras de sangue e da CLR de doadores frequentes e de $1 \underline{a}$ vez .88 


\section{LISTA DE TABELAS}

Tabela 1 - Anticorpos e seus respectivos clones utilizados na imunofenotipagem das células por Citometria de Fluxo.

Tabela 2 - Painéis de anticorpos monoclonais utilizados para imunofenotipagem celular.....45

Tabela 3 - Dados demográficos dos doadores de plaquetas por aférese. .59

Tabela 4 - Dados obtidos quando da doação de plaquetas $x$ rendimento celular obtido após isolamento de CMS.

Tabela 5 - Número total de populações leucocitárias recuperadas de amostras de sangue e da CLR 


\title{
LISTA DE ABREVIATURAS, SIGLAS E SÍMBOLOS
}

\author{
APC - Aloficocianina \\ APCs - Células Apresentadoras de Antígeno, do inglês Antigen-Presenting Cells \\ BCR - Receptor da célula $B$, do inglês $B$ cell receptor \\ ${ }^{\circ} \mathrm{C}$ - Graus Celcius \\ CAAE - Certificado de apresentação para apreciação ética \\ CBA - do inglês Cytometry bead array \\ CD - do inglês Cluster Diferentiation \\ Cel (s) - células
}

Célula NK - Célula Natural Killer

Célula NK T - Célula Natural Killer T

CFSE - do inglês Carboxyfluorescein succinimidyl ester

CLR - Câmara de Leucorredução

CMS - Células mononucleares do sangue

CTH - Células-tronco hematopoéticas

EDTA - do inglês Ethylenediamine tetraacetic acid - ácido etilenodiamino tetra-acético

FITC - Isotilcianato de fluoresceína

FSC - do inglês Foward Scatter

FSC-A - do inglês Foward Scatter - amplitude

FSC-H - do inglês Foward Scatter high

HLA - Antígeno Leucocitário Humano, do inglês Human Leukocyte Antigen

ICB - Instituto de Ciências Biomédicas

IL - Interleucina

INF- $_{\boldsymbol{y}}$ - interferon gamma

LPS - Lipopolissacarídeo

Min - minuto(s)

MHC - Complexo Principal de Histocompatibilidade

$\mathrm{mL}$ - mililitro

PE - Ficoeritrina

PerCP Cy 5.5 - Proteína clorofila peridinina-cianina 5.5

PI - lodeto de Propídeo 
PBS - do inglês Phosphate Buffered Saline

RPMI - do inglês Roswell Park Memorial Institute

SBF - Soro fetal bovino

SSC - do inglês Side Scatter

$\boldsymbol{\mu l}$ - microlitro

$\mu \mathrm{M}$ - micromolar

TCR - Receptor dos linfócitos T, do inglês $T$ cell receptor

Th - T auxiliar, do inglês $T$ helper

TNF - Fator de necrose tumoral

TLR - do inglês Toll Like Receptor 


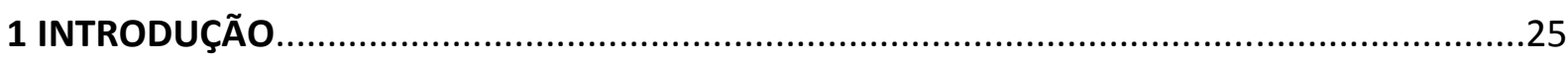

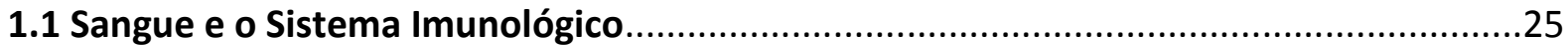

1.2 Hematopoese e Células-tronco Hematopoéticas........................................................31



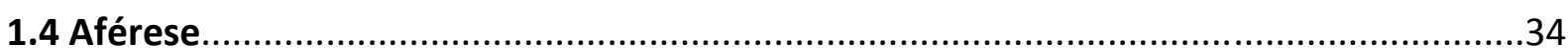

1.5 Caracterização e uso das células contidas nas Câmaras de Leucorredução.....................37

1.6 Alterações leucocitárias em doadores frequentes de plaquetas por aférese.................38

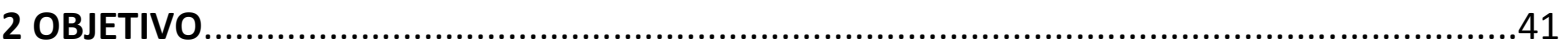

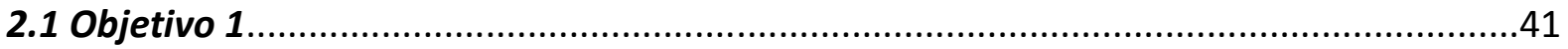

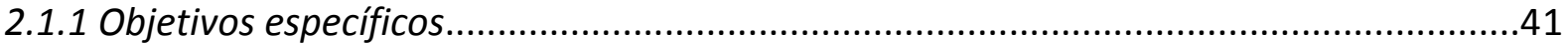

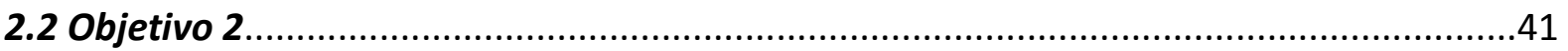

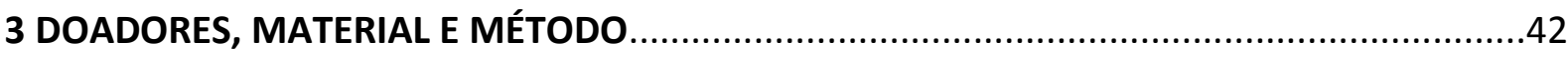

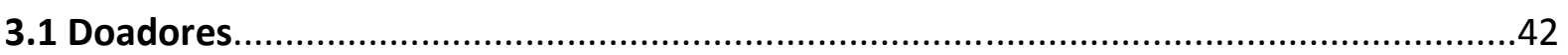

3.2 Recuperação das células da Câmara de Leucorredução.............................................43

3.3 Obtenção de células mononucleares do sangue (CMS) e da CLR...............................43

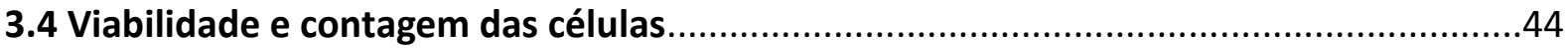

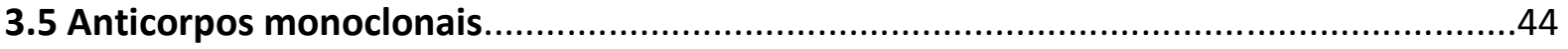

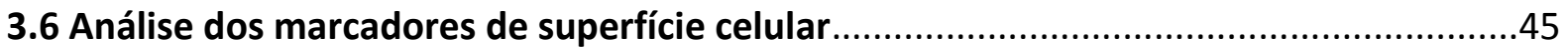

3.7 Estratégias de análise para caracterização das populações de leucócitos nas amostras de sangue e da Câmara de Leucorredução......................................................................46

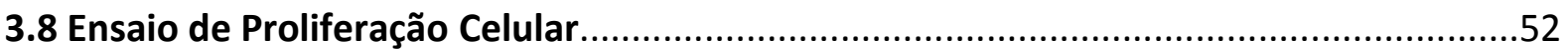

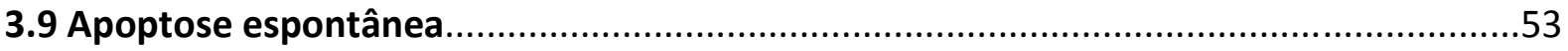

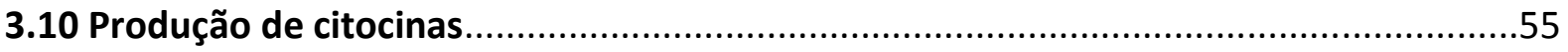

3.11 Identificação das Células-tronco hematopoéticas...................................................55

3.12 Análise comparativa de doadores de plaquetas frequentes e de $1 \mathfrak{a}$ vez.....................56

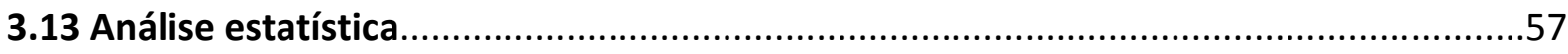

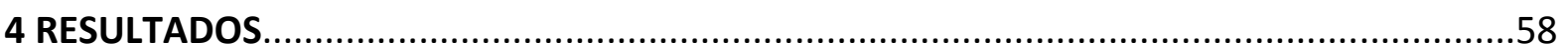



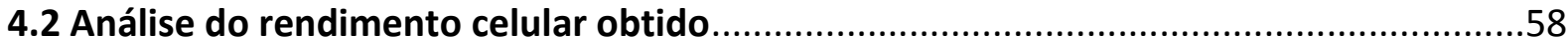

4.3 Recuperação das células das Câmaras de Leucorredução (CLR)..................................61

4.4 Análise comparativa da frequência de leucócitos em amostras de sangue e da CLR....62 
4.4.1 Análise da frequência de linfócitos totais em amostras de sangue e da Câmara de Leucorredução.

4.4.2 Análise da frequência de linfócitos $T$ em amostras de sangue e da Câmara de Leucorredução

4.4.3 Análise da frequência de linfócitos $B$ em amostras de sangue e Câmara de Leucorredução.

4.4.4 Análise da frequência de monócitos em amostras de sangue e CLR.

4.4.5 Análise da frequência de células $\mathrm{NK}$ e células $C D 3^{+} \mathrm{CD} 56^{+}$em amostras de sangue $e$ Câmara de Leucorredução

4.5 Análise do perfil funcional de linfócitos presentes em amostras de sangue e da Câmara de Leucorredução.

4.6 Análise do perfil funcional de células provenientes da Câmara de Leucorredução em comparação com amostras de sangue.

4.6.1 Análise do potencial proliferativo de linfócitos $T$ de amostras de sangue e da CLR ...75

4.6.2 Análise da produção de citocinas por células do sangue e da CLR in vitro..................78

4.6.3 Avaliação da apoptose espontânea em amostras de sangue e da CLR.

4.7 Recuperação de células-tronco hematopoéticas (CTH) provenientes da Câmara de Leucorredução em comparação com amostras de sangue

4.8 Análise comparativa de doadores de plaquetas frequentes e de 1a vez.

5 DISCUSSÃO

6 CONCLUSÕES. .98

REFERÊNCIAS .99

APÊNDICE A - Termo de consentimento Livre Esclarecido. 105

APÊNDICE B - Análises de correlação.

APÊNDICE C - Comparação do rendimento celular obtidos de amostras de sangue e da Câmara de Leucorredução de mesmo doador 


\section{INTRODUÇÃO}

\subsection{Sangue e o Sistema Imunológico}

O sangue é um tecido fluído circulante, composto por diferentes células: glóbulos brancos, glóbulos vermelhos e plaquetas, que se encontram suspensos no plasma, a parte líquida do sangue. Este tecido possui um papel fundamental na homeostasia corpórea, pois é por meio dele que os nutrientes chegam aos órgãos e tecidos através de um complexo sistema de artérias, veias e capilares. Além de nutrientes, o sangue é responsável por transportar hormônios, eletrólitos, resíduos do metabolismo celular, água e gases (oxigênio e dióxido de carbono).

O plasma corresponde a aproximadamente $55 \%$ do sangue sendo composto basicamente por água, proteínas, lipídios, glicose e sais. A porção celular, ou hematócrito, corresponde a $45 \%$ do sangue total, sendo composta pelas células vermelhas, que compreendem a maior parte, plaquetas (ou trombócitos) e os glóbulos brancos (ou leucócitos). Também é através do sangue que as células do sistema imune circulam por todos tecidos, incluindo os tecidos linfoides secundários, realizando vigilância e/ou reconhecendo situações de perigo.

O sistema imune é composto por um complexo conjunto de tecidos e células que juntos fornecem proteção contra diversos agentes que podem causar lesões ou doenças. Esses agentes podem ser substâncias químicas, microrganismos, toxinas ou mesmo reagir contra moléculas do próprio indivíduo, provocando as chamadas doenças autoimunes. Assim, o sistema imune visa prevenir o aparecimento de lesões e doenças, mas também a resolução das mesmas após seu estabelecimento. Dessa forma, a principal função do sistema imune é manter o sistema em homeostasia através da prevenção e eliminação de ameaças.

De maneira geral, o sistema imune é divido em imunidade inata e imunidade adaptativa, sendo que cada uma dessas possui células e características de reconhecimento distintas. No entanto, não trabalham de forma isolada, sendo que a interação entre os componentes de ambas é fundamental para eliminação de ameaças.

A imunidade inata é a primeira linha de defesa frente a um patógeno e é composta por barreiras físicas (ex: pele, cílios), químicas (ex: enzimas, lágrimas, saliva) e biológicas 
(células), que tem por objetivo, em um primeiro momento, impedir o estabelecimento de enfermidades. As células que compõem a imunidade inata podem ser residentes nos tecidos, como os macrófagos e células dendríticas, ou estarem presentes na circulação, como monócitos, neutrófilos, células Natural Killer (células NK) e granulócitos de maneira geral $(1,2)$. No entanto, a imunidade inata também possui componentes proteicos, como as proteínas do complemento, citocinas e quimiocinas, que são importantes no recrutamento de células para o sítio inflamatório e na interação com a imunidade adaptativa. Essa interação é de extrema importância para o desenvolvimento da resposta imune.

Em condições infecciosas, as células da imunidade inata são ativadas e se diferenciam em células efetoras a fim de eliminar a ameaça, provocando um processo inflamatório. Durante o processo inflamatório, os fagócitos (macrófagos e células dendríticas), capturam o patógeno a fim de eliminá-lo, ao mesmo tempo em que secretam citocinas e quimiocinas no sítio inflamatório recrutando células da circulação para atuar na eliminação no patógeno e potencializando a ação efetora das células ali presente (2). Quando essa primeira linha de defesa não é capaz de eliminar o patógeno, a imunidade adaptativa passa a atuar. Através da expressão de moléculas co-estimulatórias, produção de citocinas e apresentação de antígenos, a imunidade inata molda o padrão de resposta da imunidade adaptativa (3).

Os monócitos, componentes da imunidade inata, são células mononucleares originadas na medula óssea a partir de um precursor mieloide e correspondem a $10 \%$ dos leucócitos circulantes (4). São células presentes basicamente na circulação, mas também podem estar presentes no baço e pulmão, sendo recrutadas conforme a necessidade. Juntamente com os macrófagos e as células dendríticas, os monócitos pertencem ao sistema fagocitário mononuclear, e são extremamente importantes na manutenção da homeostasia, eliminando células apoptóticas, e também na resposta imune, atuando na resolução da inflamação (4-6).

Esse grupo celular pode ser diferenciado fenotipicamente e funcionalmente em dois subtipos: $\mathrm{CD}_{14}{ }^{+}$e $\mathrm{CD} 14^{\mathrm{low}} \mathrm{CD} 16^{+}$(5). As células $\mathrm{CD}_{1} 4^{+}$são consideradas os monócitos clássicos, que migram para os tecidos frente a um estímulo inflamatório, e podem se diferenciar em macrófagos ou em células dendríticas sendo que o padrão de migração e diferenciação depende do microambiente inflamatório. Já as células CD14 ${ }^{\text {low }}$ CD $16^{+}$atuam na reparação tecidual $(4,5,7)$. O CD14 em associação com receptor do tipo Toll 4 (TLR 4, do 
inglês Toll Like Receptor) auxilia no reconhecimento de lipopolissacarídeo (LPS), desencadeando a resposta imune inflamatória.

As células NK e NK-T se originam a partir de progenitores linfoides, assim como os linfócitos T e B, mas diferem destes, pois estes fazem parte da imunidade adaptativa enquanto aqueles compõem a imunidade inata e responde prontamente a entrada de patógenos. Correspondem a um conjunto de células efetoras que, além do potencial de ativamente matar os patógenos, respondem a diversos sinais produzindo citocinas que auxiliam na interação dos diferentes tipos celulares do sistema imune. Estão presentes no sangue e correspondem de 8 a $20 \%$ dos glóbulos brancos (8).

A identificação das células NK é possível através da ausência de CD3, que é característica dos linfócitos $T$, e da presença do CD56 (9). Outros marcadores também podem ser utilizados na caracterização das células NK maduras, como a ausência de TCR (receptor de linfócitos T), presença ou ausência de CD16 (receptor $\mathrm{Fc}_{\mathrm{\gamma}} \mathrm{RIII}$ ), caracterizando diferentes estágios de maturação; e a baixa expressão de CD2 (CD2 $\left.{ }^{\mathrm{dim}}\right)$ (10). As células NK ainda podem ser diferenciadas de acordo com seu estágio de desenvolvimento, apresentando um perfil imaturo ( $\left.\mathrm{CD}^{-} \mathrm{CD} 56^{\text {bright }}\right)$ ou um perfil maduro ( $\left.\mathrm{CD} 3^{-} \mathrm{CD} 56^{\mathrm{dim}}\right)$ (9). Essas células expressam receptores de membrana que são capazes de reconhecer proteínas próprias e não próprias. A ativação dessas células se dá pelo reconhecimento de proteínas não próprias, mas também pela ausência de proteínas próprias, nas células do indivíduo (11), essas proteínas compõem o Complexo Principal de Histocompatibilidade classe I - MHC I, que ativam receptores inibitórios presentes nas células NK. Essas células possuem como principal função a lise de células infectadas por vírus e/ou células tumorais (10). Além disso, podem possuir papel terapêutico importante na permanência ou rejeição de enxertos (revisado em (12)).

A chamada imunidade adaptativa entra em ação quando a imunidade inata não consegue deter a infecção. Esse tipo de resposta mais direcionada e específica contra o agente agressor é uma característica da resposta adaptativa e a diferencia da resposta imune inata. Essa especificidade se deve aos receptores presentes nos linfócitos, que são a população celular chave da resposta imune adaptativa. Outra característica importante da reposta adaptativa está na capacidade de desenvolver memória frente a um antígeno após um encontro com o mesmo. As células da imunidade adaptativa podem ser encontradas 
circulantes no sangue e no sistema linfático, como também nos órgãos linfoides secundários, como baço e linfonodos (2).

A resposta imune resultante da ativação do TCR pode ter uma característica de tolerância, ou seguir um dos dois padrões clássicos de resposta: a resposta do tipo Th1 ou do tipo Th2. Esses padrões de resposta dependem do microambiente em que se deu a ativação do linfócito T e também do fator ativador do TCR. De maneira geral, infecções causadas por helmintos ativam o padrão de resposta Th2, enquanto que infeções causadas por bactérias e vírus, ativam o padrão de resposta Th1 (11).

Após a ativação provocada por antígenos, os linfócitos T passam por um processo de expansão, denominado expansão clonal, com o objetivo de eliminar o patógeno. Após a resolução da doença a maioria das células efetoras morre, mas uma pequena fração delas sobrevive, constituindo uma população celular de memória (13). O pool de células virgem (do inglês naïve) e células de memória é controlado por mecanismos homeostáticos. Entre os sinais responsáveis pela sobrevivência dos linfócitos T naïve estão: a sinalização via seu receptor (TCR), proveniente da interação com MHC apresentando peptídeos próprios, e a sinalização de citocinas como IL-15 e IL-7, em menor escala. A sobrevivência dos linfócitos T de memória por sua vez, parece ser menos dependentes da interação com MHC e mais dependente das citocinas IL-15 e IL-7 que controlam a proliferação e a sobrevivência, respectivamente, além de serem importantes na proliferação homeostática e na sobrevivência dos linfócitos T CD4 ${ }^{+}$e $\operatorname{CD}^{+}(13,14)$.

Os linfócitos T podem ser subdivididos em dois tipos principais, de acordo com a sua função: os linfócitos T auxiliares (T CD4 $\left.{ }^{+}\right)$e os linfócitos T citotóxicos (T CD8 $\left.{ }^{+}\right)$. Enquanto o primeiro tem por função regular a resposta imune, o último tem por objetivo destruir células infectadas por patógenos intracelulares e células anormais, como células tumorais. Para identificá-los imunofenotipicamente, utilizam-se anticorpos monoclonais para proteínas de superfície de membrana. Para identificar os linfócitos T é comum a utilização do anticorpo monoclonal anti-CD3 e, para diferenciar os subtipos de linfócitos T, são utilizados os anticorpos monoclonais anti-CD4 e anti-CD8 para linfócitos T auxiliares e citotóxicos, respectivamente.

Os linfócitos B correspondem a aproximadamente 15\% dos leucócitos presentes no sangue (15). São células da imunidade adaptativa, que, assim como os linfócitos $T$, promovem proteção específica e de longa duração frente aos mais diversos antígenos. São 
células capazes de reconhecer tanto antígenos solúveis, como antígenos apresentados pelas Células Apresentadoras de Antígenos (APCS), como as células dendríticas e os macrófagos (16), esse reconhecimento se dá através do receptor da célula $B(B C R)$ e leva à ativação da célula. Uma vez ativada, a células B passa por um processo de proliferação e diferenciação, tendo a capacidade de se diferenciar em plasmócitos ou em células $B$ de memória. Além de produtoras de anticorpos, as células B também atuam como APCs e secretam citocinas, influenciando assim a resposta imune. Uma vez que também atuam como uma APC, embora não sejam apresentadoras profissionais, elas possuem a capacidade de ativar os linfócitos $T$ desencadeando assim uma resposta frente a um antígeno ou até mesmo um antígeno próprio (17).

Esse grupo celular pode ser subdivido em dois tipos, os linfócitos B1, que estão presentes nas mucosas e nas cavidades peritoneais, e respondem prontamente a entrada de antígenos produzindo anticorpos, auxiliando assim na imunidade inata; e os linfócitos B2, que atuam na imunidade adaptativa respondendo de forma tardia a entrada do antígeno, se diferenciando em plasmócitos de vida longa ou em células B de memória. Os linfócitos B2 são os linfócitos B tradicionais, cuja origem se dá de precursores presente na medula óssea (18) sendo identificado imunofenotipicamente pela presença do co-receptor CD19.

Linfócitos T e B de maneira geral podem ser caracterizados como células naïve, efetoras ou de memória. As células T naïve correspondem àquelas células que ainda não entraram em contato com antígeno. As células T efetoras estão presentes devido a estímulo antigênico originado de diferentes maneiras, enquanto que as células T de memória estão presentes mesmo na ausência do estímulo antigênico, sendo capazes de se expandir rapidamente quando estimuladas (19). A caracterização do perfil de ativação e diferenciação é importante na validação de uma nova fonte de leucócitos, por isso é importante a comparação de amostras provenientes das CLR em comparação com as do sangue.

Uma das maneiras de analisar o perfil de diferenciação dos linfócitos T é através da expressão das isoformas do receptor de membrana CD45. O CD45 é uma tirosina fosfatase expressa em todos os leucócitos. Esses receptores de tirosina fosfatase desempenham importante papel na sinalização via os receptores de células T (TCR) e B (BCR), no entanto, sua função é mais bem estudada nos linfócitos T (20). As diferentes isoformas dessa proteína (CD45R) permite a diferenciação dos estágios de desenvolvimento dos linfócitos T. Após ativação, ocorre uma mudança no padrão de isoformas expressos na superfície do linfócito 
T. A isoforma com alto peso molecular (CD45RA) é gradualmente perdida e substituída por uma isoforma de baixo peso molecular (CD45RO) (21). As células CD45RA ${ }^{+}$são consideradas como células naïve por serem menos responsivas a antígenos, ao contrário das células

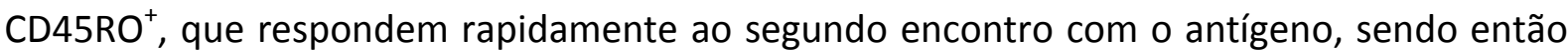
consideradas como células de memória (22).

As células T periféricas expressam ou CD45RA ou CD45RO, sendo que uma porção significante dessas células expressa ambas as proteínas (21). Estudos mostram que a presença de células expressando ambos marcadores se deve ao fato de células CD45RA$\mathrm{CD}^{2} 5 \mathrm{RO}^{+}$ganharem novamente a expressão de $\operatorname{CD} 45 \mathrm{RA}(21,23)$. As células T CD45RA migram quase que exclusivamente pelos tecidos linfoides, enquanto que as T CD45RO ${ }^{+}$ migram pelo corpo e superfícies epiteliais. A razão para isso é que as células naïve tem baixa probabilidade de encontrar seu antígeno específico, que são levados para os linfonodos pelas células dendríticas. Em contraste, as células de memória e efetoras migram para os tecidos periféricos, se tornando mais vulneráveis ao encontro com antígenos. O problema é que tanto células efetoras como as células de memória expressam CD45RO, sendo difícil fazer a distinção entre as duas $(24,25)$. A expressão do receptor de quimiocina CCR7, junto com a expressão do CD45RO poderia auxiliar nessa distinção. Segundo Sallusto e colaboradores (1999) (25), as células $\mathrm{CD}^{2} 5 \mathrm{RO}^{+} \mathrm{CCR} 7^{-}$apresentam um perfil efetor, caracterizado pela rápida produção de citocinas, com IFN- $\gamma$, IL-4 e IL-5. Já as células $\mathrm{CD} 4 \mathrm{RO}^{+} \mathrm{CCR7}^{+}$apresentam ausência de características de células efetoras (24).

Embora diferentes autores usem a combinação de diversos marcadores para caracterização do perfil de ativação dos linfócitos T (se naïve, efetora ou de memória), como CD27 e CD45RA (26), CCR7 e CD45RA (25), CD27 e CD28 (27), o uso das isoformas (CD45RA e CD45RO) do marcador leucocitário CD45 é muito utilizada. Esses receptores de tirosina fosfatase estão envolvidos no processo de ativação dos linfócitos T (19). Esses estudos propõem diferentes estágios de ativação das células $T$, no entanto, abordamos apenas as definições clássicas de uma população naïve, intermediária (efetoras) e de memória, baseada nesse marcador.

Juntas, essas células compõem a defesa do organismo. Qualquer alteração em um desses componentes, seja por excesso ou por falta dessas células, pode comprometer as funções do sistema imune e provocar uma série de malignidades ao indivíduo. Os principais grupos caracterizados nesse trabalho são os linfócitos T, linfócitos B, monócitos e células NK. 
Apesar do sistema imune e seus componentes terem como função primordial a manutenção da homeostasia e a eliminação de patógenos, muitas vezes a atuação desse sistema pode ser danoso ao indivíduo. Em determinadas condições, como, por exemplo no câncer, células que deveriam atuar na eliminação dos tumores, como os macrófagos, acabam por serem moldadas pelo microambiente tumoral e atuam promovendo a permanência do mesmo seja através de um ambiente imunossupressor ou através da promoção de angiogênese (28). Dessa forma, é importante uma fonte segura e abundante de células que permita o estudo dos parâmetros envolvidos na resposta imune, seja nos mecanismos de ação, na resposta exacerbada, vias de sinalização entre outros.

\subsection{Hematopoese e Células-tronco Hematopoéticas}

As células-tronco hematopoéticas (CTH) tem por função primordial a produção de células sanguíneas durante todo período de vida. A esse processo, dá-se o nome de hematopoese. As CTH são capazes de manter a produção de células sanguíneas através de um balanço entre o processo de autorrenovação e de diferenciação (29). Nas primeiras semanas de gestação, a hematopoese ocorre no saco vitelino e a partir do sexto mês, passa a ocorrer no fígado e baço, que continuam a produzir células sanguíneas até mais ou menos duas semanas após o nascimento. No sexto ou sétimo mês de vida fetal é que a medula óssea passa a produzir células sanguíneas e permanece nessa função durante toda a vida adulta. Além da medula óssea, há tecidos linfoides (presentes no baço, timo, amígdalas, gânglios linfáticos, e placas de Peyer) que contribuem para formação de células do sangue $(30,31)$.

A hematopoese ocorre a partir de células-tronco pluripotentes, capazes de originar diversos tipos celulares e com alto poder de autorrenovação e proliferação. A célula-tronco hematopoética (CTH) é um tipo de célula-tronco com capacidade de diferenciação para os diversos tipos de células do sangue. Esta célula está presente no estroma da medula óssea, que fornece um microambiente favorável para o crescimento e desenvolvimento celular e fatores de crescimento e de diferenciação celular que são necessários para a sobrevivência da CTH. A interação de todos esses fatores com a CTH leva à produção de células progenitoras para duas linhagens principais: a linhagem mieloide, que dá origem aos 
granulócitos, eritrócitos, monócitos e plaquetas; e a linhagem linfoide, que dá origem aos linfócitos e células NK (32).

De modo geral as células sanguíneas maduras possuem vida curta, assim as CTH precisam tanto se autorrenovar quanto se diferenciar nos progenitores da linhagem sanguínea constantemente, a fim de manter as quantidades necessárias de células circulantes no sangue. As CTH são mais comumente encontradas na medula óssea (1 a 3\%), entretanto podem ser encontradas em menor concentração no sangue (cerca de $0,1 \%$ ) (32). O potencial de reconstituir as diferentes linhagens sanguíneas faz da CTH uma ferramenta importante na terapia celular, sendo de extrema importância o desenvolvimento de técnicas para a identificação e isolamento dessas células. O fato dessa população não ser facilmente encontrada é uma barreira no desenvolvimento de terapias celulares envolvendo CTH (33).

Durante o processo de hematopoese e diferenciação, as células sanguíneas expressam e deixam de expressar diversas proteínas de superfície, que servem como marcadores de acordo com o estágio de diferenciação. A proteína de membrana CD34, que auxilia na adesão das células ao estroma medular, foi um dos primeiros marcadores utilizados da identificação de CTH e ainda hoje é o mais utilizado na identificação das mesmas. A presença dessa glicoproteína, juntamente com a ausência de marcadores linhagem-específicas como marcadores de monócitos (CD14), linfócitos (CD3 e CD19) e NK (CD56), pode ser utilizada para auxiliar na identificação de células imaturas, diferenciando-as de células maduras. Entretanto, outras células como células endoteliais e fibroblastos também expressam CD34 em sua superfície (32), assim, para caracterização das células de $\mathrm{CD}_{3} 4^{+}$de origem hematopoética, também se deve levar em conta a baixa expressão do marcador leucocitário CD45.

Visto que a concentração de células $\mathrm{CD} 4^{+}$no sangue é muito baixa, uma forma de enriquecer a porção $\mathrm{CD} 34^{+}$no sangue para utilização em terapia celular é através do tratamento dos doadores com fatores quimiotáticos para essas células (como o fator de formação de colônias granulocíticas (G-CSF) ou o fator estimulante de colônias granulocíticomacrofágicas (GM-CSF)) $(30,31,34)$. Entretanto, a administração desses fatores pode acarretar efeitos adversos nesses indivíduos. Dessa forma, mostra-se necessária uma fonte alternativa de obtenção dessas células para uso em terapias celulares e em pesquisa. 


\subsection{Doação de sangue e hemocomponentes}

A doação de sangue é uma ação voluntária e altruísta, sendo a única forma de obtenção de hemocomponentes para o paciente que precisa receber transfusão. Estima-se que, só no ano de 2011, houve aproximadamente 90 milhões de doações de sangue pelo mundo (35).

A doação de sangue é considerada segura, no entanto, como qualquer procedimento médico, não está isenta do risco de efeitos adversos tanto no doador como no receptor do sangue. Para prevenir a ocorrência destes efeitos adversos no doador, o mesmo deve estar dentro dos requisitos pré-estabelecidos para realizar a doação. A fim de evitar efeitos adversos para o receptor do sangue, o material doado passa por uma série de exames laboratoriais, como exames para verificação do vírus da hepatite B e C, HIV, sífilis, entre outros. Somente após o resultado dos exames o sangue é liberado para uso $(36,37)$.

A Portaria 1353, aprovada em 2013 pelo Ministério da Saúde, regulamenta e define os critérios de seleção para doação de sangue: ter idade entre 16 e 69 anos, (menores de 18 anos podem ser aceitos com autorização expressa do responsável legal); peso acima de 50 kg; estar em boas condições de saúde; ter dormido pelos menos 6 horas nas últimas 24 horas; estar alimentado, evitando alimentos gordurosos nas horas anteriores à doação. Ainda segundo esta portaria, algumas situações determinam a inaptidão temporária para doação de sangue, tais como: infecções virais ou bacterianas ativas ou recentes; gravidez; parto recente (90 dias se parto normal e 180 dias se cesariana); cirurgias recentes; tatuagem há menos de 12 meses; situações de risco acrescido de exposição a agentes infecciosos transmissíveis pelo sangue há menos de 12 meses. Algumas condições, no entanto, determinam a inaptidão definitiva para doação de sangue: histórico de hepatite viral após os 11 anos de idade; histórico ou resultado laboratorial reagente para agentes infecciosos transmissíveis pelo sangue (vírus das hepatites B e C; vírus HIV; vírus HTLV I/II; doença de Chagas; sífilis); uso de drogas ilícitas injetáveis; histórico de câncer ou outros tumores; doenças cardíacas, pulmonares, imunológicas, etc. Além disso, existem parâmetros definidos de pressão arterial, frequência cardíaca, nível de hemoglobina e temperatura para que seja permitida a doação de sangue.

A fim de preservar a saúde do doador, em uma doação de sangue convencional, o intervalo mínimo recomendado entre cada doação é de 02 meses para homens e 03 meses 
para mulheres, e são permitidas no máximo 04 e 03 doações/ano, respectivamente, que é o tempo necessário para reposição do estoque de ferro. Além disso, o volume coletado numa doação convencional de sangue pode variar entre 400 e $500 \mathrm{~mL}$, considerando-se como coleta máxima de $8 \mathrm{~mL} / \mathrm{kg}$ de peso no sexo feminino e $9 \mathrm{~mL} / \mathrm{kg}$ de peso no sexo masculino. $\mathrm{O}$ sangue é coletado em bolsas plásticas específicas que contém solução anticoagulante, usualmente o citrato de sódio. Em seguida, é comum o fracionamento do sangue total, a partir do qual são gerados concentrados de hemácias, plaquetas, plasma fresco congelado e crioprecipitado $(31,38)$.

O avanço no tratamento de doenças oncológicas e surgimento de procedimentos cirúrgicos cada vez mais complexos têm contribuído para o aumento da demanda transfusional, o que traz ao banco de sangue o desafio de manter estoque suficiente de hemocomponentes para atender esta demanda. A transfusão de plaquetas, por exemplo, é frequente no manejo terapêutico de pacientes oncológicos submetidos a tratamento químio ou radioterápico, e pacientes submetidos a transplante de órgãos, principalmente de medula óssea. A obtenção de quantidade suficiente de plaquetas para transfusão de uma dose adequada num paciente adulto requer, em geral, 05 a 06 doações convencionais de sangue. Um método que permite a obtenção de quantidade adequada de plaquetas de um único doador e que vem sendo cada vez mais utilizado é a doação por aférese $(38,39)$. Este tipo de doação é importante, pois diminui a exposição do paciente a vários tipos de antígeno leucocitário humano (HLA), uma vez que é possível obter grandes quantidades do componente a partir de um mesmo doador (40).

\subsection{Aférese}

O termo aférese ou hemaférese refere-se à retirada do sangue total de um paciente ou doador, seguida da sua separação nos vários componentes através de filtração ou centrifugação, retenção do plasma (plasmaférese) ou de um componente celular específicos do sangue (citaférese) (41), como a retiradas dos eritrócitos (eritrocitaférese), dos leucócitos (leucoaférese) ou das plaquetas (trombo ou plaquetaferese).

Os procedimentos de aférese podem ter objetivos terapêuticos, ou transfusionais. A aférese terapêutica tem sido empregada no tratamento de várias patologias com o objetivo de remover um elemento patogênico ou uma substância fisiológica presente em 
concentrações indesejáveis na circulação (42). A aférese transfusional, por sua vez, visa à obtenção de um ou mais hemocomponentes a partir de um doador único, a fim de transfundir o componente sanguíneo no paciente.

O princípio desta metodologia utiliza as diferentes características dos componentes sanguíneos em relação ao seu tamanho, peso e densidade para a separação e coleta seletiva.

A separação dos componentes sanguíneos em relação as suas características físicas (peso, tamanho e densidade) resulta na formação de uma fina interface leucoplaquetária, onde estão contidas as células do sangue. Nesta camada, as células também estão dispostas de acordo com a sua densidade e a separação de cada grupo celular é muito tênue. Os granulócitos estão na base dessa interface, seguida pelos monócitos, linfócitos e plaquetas. Dessa forma, os componentes sanguíneos ficam dispostos da seguinte maneira: as células vermelhas ficam na porção inferior, acima dela está a interface leucoplaquetária e acima desta interface está o plasma.

A coleta do concentrado de plaquetas por aférese é feita desde os anos 1960, com equipamentos manuais e a coleta automatizada começou a ocorrer por volta de 1975 (43). Nos anos 80 e 90 houve um rápido aumento na prática de transfusão de plaquetas e em 1994, pela primeira vez, o concentrado de plaquetas obtido por aférese correspondeu a 50\% das doações sanguíneas (44).

Nos equipamentos mais antigos utilizados na doação por aférese, as plaquetas obtidas possuíam contaminação de leucócitos, o que leva à ocorrência de reações adversas como reação febril não hemolítica, além do risco de transmissão de citomegalovírus em pacientes imunodeprimidos e suscetíveis. Desta forma, a prevenção destas complicações requer a leucorredução do hemocomponente, ou seja, remoção seletiva dos leucócitos do concentrado de plaquetas durante ou posteriormente à coleta. Os equipamentos atuais para coleta por aférese permitem a obtenção de concentrado de plaquetas com alto grau de pureza. Nestes sistemas, o processo de leucorredução é realizado durante a coleta por um processo conhecido como elutriação, no qual o sangue é centrifugado em uma cinta plástica para que ocorra a formação da camada leucoplaquetária na própria cinta. As hemácias retornam para o doador e a fração superior da Interface é coletada na Câmara de Leucorredução (CLR) (Figura 1). 
Figura 1 - Processo de separação automatizada das plaquetas.

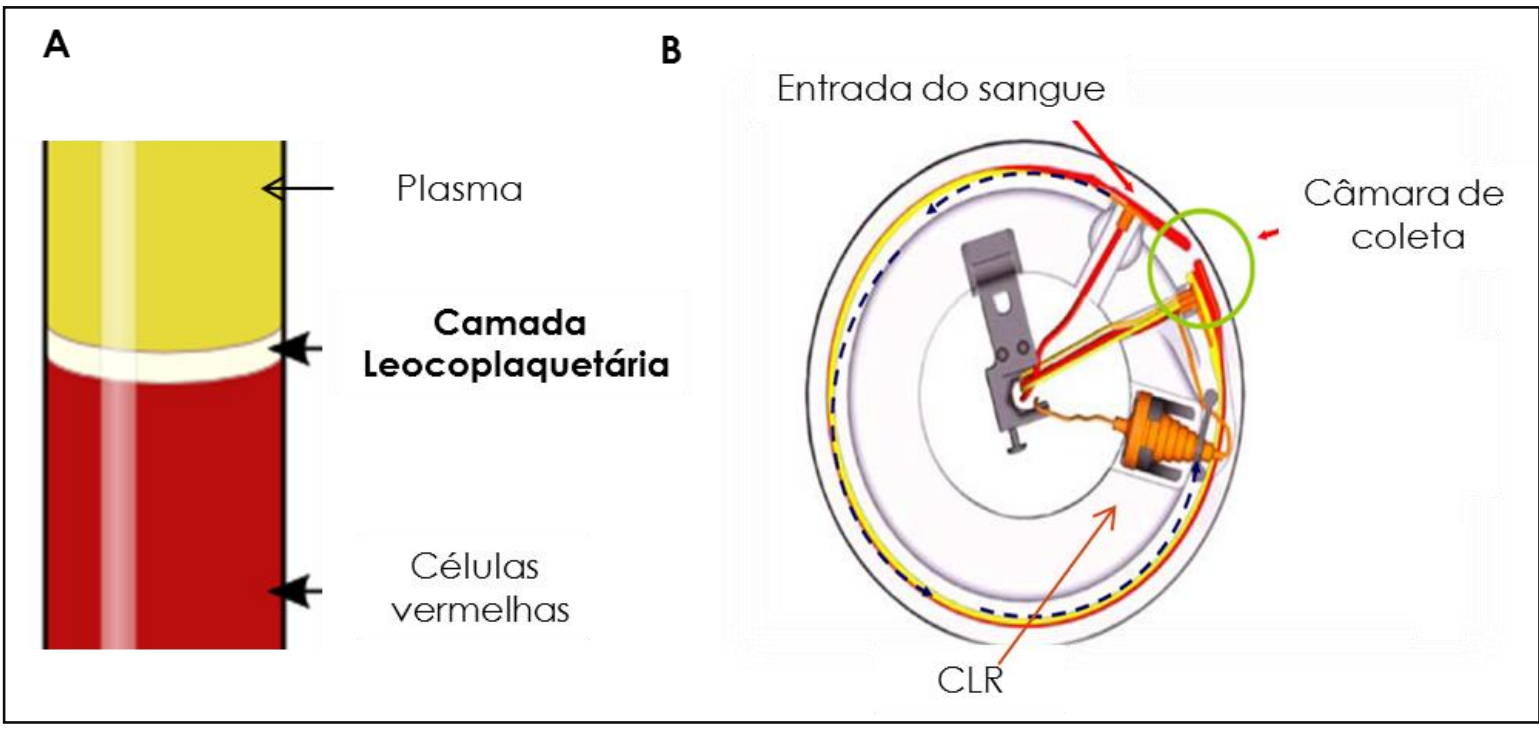

(A) Formação da camada leucoplaquetária na cinta de centrifugação do aparelho;

(B) Diagrama esquemático da cinta de centrifugação e Câmara de Leucorredução (CLR).

Crédito das imagens CaridicinanBCT

A Câmara de Leucorredução é uma estrutura plástica piramidal acoplada ao sistema de centrifugação, comumente apelidada nos serviços de banco de sangue como "pião" devido à sua semelhança com o brinquedo (Figura 2).

Figura 2 - Câmara de Leucorredução.

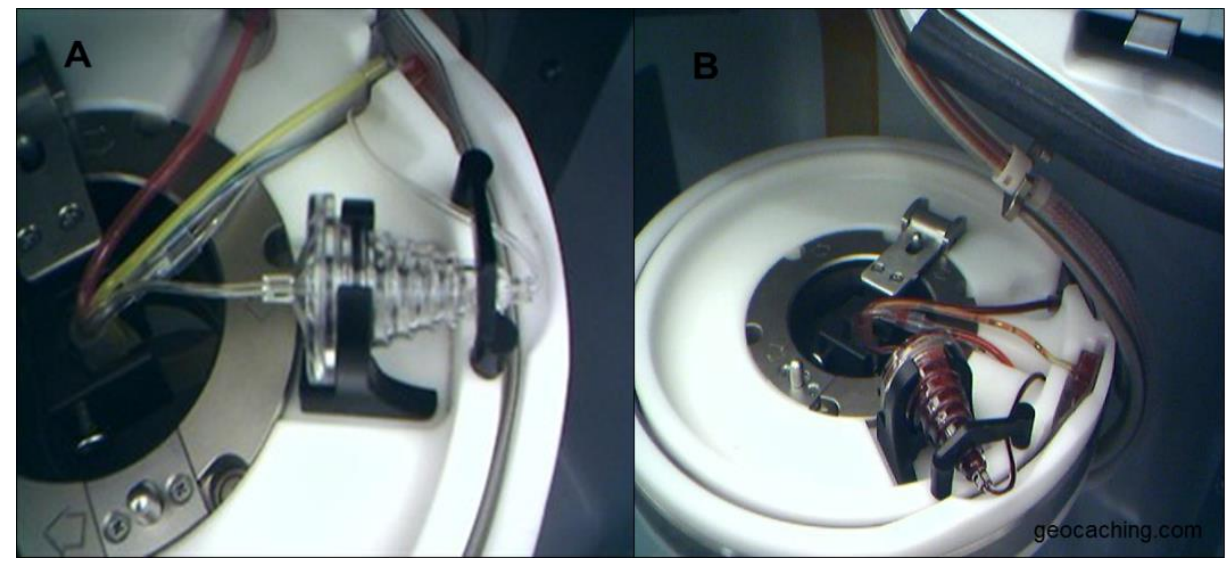

Antes (A) e após (B) o processo de doação de plaquetas por aférese. Crédito da imagem: www.geocaching.com

Ao término da doação a câmara é descartada contendo em seu interior uma grande quantidade de leucócitos. Alguns trabalhos têm mostrado a viabilidade das células contidas na câmara, sejam elas linfócitos ou monócitos. Dietz e colaboradores (2006) (45) mostraram que a CLR possui os principais grupos leucocitários, como linfócitos $T$, linfócitos $B$, monócitos 
e células NK, e ainda, que essas células são passiveis de ativação frente a estímulos. Por usa vez, Neron e colaboradores (2007), mostraram que as células provenientes da CLR podem ser congeladas e descongeladas e ainda assim a proporção dos leucócitos ser semelhante àquela encontrada no sangue (46). Outros demonstram a possibilidade de obtenção de células-tronco hematopoéticas a partir de filtros de leucorredução (47). Dessa forma, as células viáveis provenientes da Câmara de Leucorredução poderiam ser uma fonte prática e abundante de células para uso em projetos de pesquisa. A validação da viabilidade dos tipos celulares obtidos por esse método mostra-se necessária, frente à dificuldade na obtenção de amostras de indivíduos saudáveis (controles) em pesquisas.

\subsection{Caracterização e uso das células contidas nas Câmaras de Leucorredução}

O concentrado de plaquetas com alto grau de pureza (leucorreduzido) pode ser adquirido por filtragem após a doação de sangue total ou através de doação de plaquetas por aférese. Em ambos os casos os filtros e as câmaras são descartados, contendo grande quantidade de leucócitos. Os estudos existentes sobre a utilização do material contido nesses leucorredutores foca mais na utilização dos filtros de leucorredução e não tanto na utilização das Câmaras de Leucorredução como fonte alternativa de leucócitos e células progenitoras.

Os estudos envolvendo os filtros de leucorredução mostraram que eles fornecem grande quantidade de leucócitos (cerca de $5,1 \times 10^{8}$ ) assim como seus vários subtipos, como linfócitos $\mathrm{TCD}^{+}, \mathrm{TCD}^{+}$, linfócitos $\mathrm{B}$, células NK e monócitos, e mostram também que essas células são viáveis, respondem a estímulos, além de fornecerem quantidades significativas de DNA para uso em pesquisa. Além de células diferenciadas, os filtros também são fontes de progenitores celulares, como progenitores endoteliais $(45,48-51)$.

Outros estudos comparam o rendimento celular dos filtros de leucorredução e das Câmaras de Leucorredução mostrando que a CLR possui uma quantidade considerável de células em seu interior, sendo uma fonte mais abundante de leucócitos que os filtros de leucorredução. Esses estudos mostram que é possível recuperar aproximadamente $1,88 \times 10^{9}$ leucócitos por câmara (45). Comparando o rendimento de leucócitos originados a partir da camada leucoplaquetária de células do sangue total com sangue proveniente da Câmara de Leucorredução, os estudos mostram que o rendimento das Câmaras de Leucorredução é 
consideravelmente maior. Enquanto que, de $20 \mathrm{~mL}$ de sangue total de um indivíduo saudável seria possível extrair de 0,08 a $0,20 \times 10^{9}$ células brancas (48), uma única câmara fornece de 0,7 a $0,9 \times 10^{9}$ células retiradas da interface leucoplaquetária (46). Além de leucócitos, estudos mostram que a CLR podem ser uma importante fonte de células-tronco hematopoéticas $\left(\mathrm{CD} 34^{+}\right)(46)$.

Procedimentos como purificação de populações celulares requerem grandes quantidades de amostras de sangue, assim, é imprescindível a obtenção de fontes celulares que forneçam quantidade de células suficiente. Comparado com os filtros, a Câmara de Leucorredução é de mais fácil manuseio. Enquanto o primeiro precisa ser cuidadosamente lavado e depois realizada a separação da camada mononuclear, a amostra proveniente da câmara pode ser manuseada como amostra convencional de sangue, dispensando qualquer tipo manuseio especial da mesma.

Corriqueiramente amostras de sangue são retiradas de companheiros do próprio laboratório, e essas amostras não passam por nenhum tipo de teste, apenas presume-se que o indivíduo é saudável. As Câmaras de Leucorredução são provenientes do banco de sangue, dessa forma, é certo que o material doado passou uma série de testes, assegurando que aquela amostra é de indivíduo saudável.

\subsection{Alterações leucocitárias em doadores frequentes de plaquetas por aférese}

A doação de sangue, mesmo em condições ideais, pode provocar reações adversas, as principais reações adversas relatadas são as manifestações imediatas tais como tontura e queda de pressão. Os estudos sobre os efeitos em longo prazo de doações de sangue convencional e por aférese são escassos. Estima-se que em cada doação de sangue total, o doador perca aproximadamente $1 \times 10^{9}$ linfócitos a cada $500 \mathrm{~mL}$ de sangue doado. Estudos

demostraram haver redução de leucócitos em doadores frequente de sangue (52), mas como o intervalo entre cada doação limita o número de doações por ano para no máximo 4 doações, a perda total de linfócitos nesse período não resultaria em uma sobrecarga do sistema hematopoético (53). Entretanto, o mesmo não pode ser afirmado em relação à doação de plaquetas por aférese, que é realizada com uma frequência muito maior do que a doação de sangue convencional (é permitido um intervalo mínimo de 48 horas entre duas 
doações e o máximo de 24 doações por ano) o que poderia resultar em uma perda mais significativa dos componentes celulares sanguíneos.

Estudos utilizando aparelhos de aférese modernos demonstram que em cada doação de plaquetas há uma perda média de linfócitos de $0,009 \times 10^{9} / L$ (54). Análise do número células brancas realizadas pré e imediatamente após a doação de plaquetas mostra uma redução média de 5,14\% de leucócitos totais (55). Dessa forma, uma das preocupações com a doação frequente de plaquetas por aférese é justamente a ocorrência de efeitos adversos em longo prazo, dentre eles alterações significativas nos componentes sanguíneos do doador.

Na literatura, são escassos os estudos a respeito de tais alterações e as opiniões existentes são divergentes. Há estudos que demonstram que a doação frequente pode alterar a população linfocitária do doador. Outros estudos mostram que ocorre alteração de acordo com o produto coletado, mas que esta alteração não afetaria significativamente o doador. Outros ainda observam perdas significativas de linfócitos, mas não atribuem nenhum risco clínico a essa perda $(36,44,53,54,56)$. No entanto, o tempo entre as doações, e o tipo de doação realizada (a doação de plaquetas pode ser classificada simples, dupla ou tripla, em função do número de bolsas coletadas) interfere na contagem dos linfócitos. Estudos mostram que doadores que realizaram entre 6 e 10 doações, entre a primeira e última doação, apresentam maior perda linfocitária quando comparados a doadores que realizaram menos doações (54).

Utilizando-se modelos clínicos, em que a aférese é usada de forma terapêutica, com o objetivo de retirar células do paciente, uma imunodeficiência clínica significante ocorreria quando o nível de linfócitos no sangue estaria abaixo de $1 \times 10^{9} \mathrm{cel} / \mathrm{L}$ ou quando os níveis de IgG seriam inferiores a $200 \mathrm{mg} / \mathrm{dL}$ (53). Durante uma aférese simples, com separadores de células de geração mais antiga, a perda linfocitária variava entre $1 \times 10^{9}$ a $10 \times 10^{9}$, sendo que esse valor pode variar dependendo da técnica, chegando a $10^{7}-10^{8}$ linfócitos por procedimento. Estudos que comparam dados de pré e pós-doação, observam diminuição de $20 \%$ na contagem dos linfócitos, no entanto, essa diminuição é transiente e não causa disfunção imunológica $(53,57)$.

Nos aparelhos de aférese mais modernos, a perda de linfócitos por doação é consideravelmente menor (aproximadamente $10^{6}$ linfócitos/procedimento), no entanto, as doações podem ser combinadas, sendo possível a doação de plaquetas e plasma ou 
plaquetas e células vermelhas em um único procedimento. Essa possibilidade de poder doar vários componentes sanguíneos de uma só vez também traz preocupações sobre o doador (53). Estudos compararam também os níveis de albumina e proteínas totais nos doadores de plaquetas e observaram que não há alteração significativa quando comparados com doadores de sangue total (58). Além da possível ocorrência de leucopenia, há também a possibilidade de possível perda de plaquetas. Os estudos sobre esse assunto também divergem $(40,58)$.

A maioria dos trabalhos realizados nessa área utilizam aparelhos antigos onde a perda de linfócitos é maior quando comparados com os aparelhos atuais. Nesses estudos, observa-se redução significativa dos linfócitos T CD4, $\operatorname{TCD} 8$ e linfócitos $B(57,59,60)$. No entanto, pouco se sabe sobre as alterações dos leucócitos em doadores frequentes utilizando-se os aparelhos de aférese atuais, em que a perda leucocitária é menor. Nesse sentido, é de extrema importância a avaliação da perda leucocitária em doadores frequentes de plaquetas visando afirmar a segurança deste procedimento e o incentivo para aumento das doações.

Dessa forma, esse trabalho visa, além da validação da viabilidade dos tipos celulares obtidos da Câmara de Leucorredução, a comparação das populações leucocitárias entre doadores frequentes de plaquetas e doadores de primeira vez, a fim de avaliar os níveis de leucócitos desses pacientes. 


\section{OBJETIVO}

\subsection{Objetivo 1}

Avaliar a viabilidade do uso das células descartadas nas Câmaras de Leucorredução (CLR), oriundas do procedimento de doação de plaquetas por aférese, a fim de aperfeiçoar a utilização dessas células e de reduzir o número de pacientes/controles a serem incluídos nesses diferentes estudos.

\subsubsection{Objetivos específicos}

Analisar nas células descartadas na CLR quanto a:

- Tipos celulares presentes na Câmara de Leucorredução;

- Distribuição das diferentes populações celulares da câmara;

- Estado de ativação linfocitária e capacidade proliferativa dessas células;

- Presença de células-tronco hematopoéticas.

Comparação desses fenótipos aos observados/encontrados em amostras de sangue.

\subsection{Objetivo 2}

Avaliar e comparar as populações celulares do sangue de doadores de plaquetas por aférese de primeira vez e de doadores frequentes, a fim de verificar se doadores frequentes podem sofrer algum tipo de alteração leucocitária resultante de repetidas doações de plaquetas. 


\section{DOADORES, MATERIAL E MÉTODO}

\subsection{Doadores}

Os doadores de plaquetas foram abordados pela equipe de enfermagem do Banco de Sangue do Hospital Albert Einstein durante triagem que antecede o procedimento de doação de plaquetas. Todos os doadores que voluntariamente aceitaram participar do presente trabalho leram e assinaram o "Termo de Consentimento Livre Esclarecido" (TCLE) (APÊNDICE A), aprovado pelo Comitê de Ética dos institutos envolvidos, registrados sob CAAE no 07136512.1.1001.5467 (ICB/USP) e CAAE no 07136512.1.2002.0071 (CEP Hospital Israelita Albert Einstein).

Antes do início da aférese, foi coletada uma alíquota de sangue venoso, entre 5 e 10 $\mathrm{mL}$, em tubos contendo 1,8 mg de EDTA-K3 (do inglês Ethylenediamine tetraacetic acid ácido etilenodiamino tetra-acético) para cada $\mathrm{mL}$ de sangue (Tubos VACUETTE ${ }^{\circledR}$, Greiner Bio One® , Campinas, São Paulo, Brasil); essa amostra foi mantida a temperatura ambiente, a fim de ser comparada com o material coletado da Câmara de Leucorredução (CLR), nas diferentes análises a serem realizadas nesse estudo. Ao término da doação, a CLR foi separada e mantida em temperatura ambiente até o momento dos processamentos descritos a seguir.

As amostras de sangue e do conteúdo da CLR foram processadas em até 24 h após a doação.

Para comparação da população celular, bem como para os ensaios funcionais, entre amostras de sangue e da CLR de mesmo doador, foram utilizadas as amostras de doadores esporádicos, independente do número e da frequência de doações de plaquetas por aférese realizadas anteriormente. Para comparação de amostras de sangue entre doadores frequentes e de primeira vez, foram considerados doadores frequentes aqueles que realizaram no mínimo 6 doações de plaquetas por aférese nos últimos 12 meses; e foram considerados doadores de primeira vez aqueles cuja doação de plaquetas era a primeira a ser realizada. Doadores que tenham realizado outras doações de plaqueta por aférese em outros Bancos de Sangue, não se encaixaram no critério de primeira vez. 


\subsection{Recuperação das células da Câmara de Leucorredução}

A recuperação do conteúdo presente na CLR foi feita de forma asséptica, dentro de fluxo laminar. Resumidamente, a extremidade inferior da Câmara foi cortada com o auxílio de uma tesoura estéril e a Câmara foi colocada sobre um tubo cônico de $50 \mathrm{~mL}$. A extremidade superior foi então cortada e o conteúdo da Câmara foi transferido para o tubo cônico.

As células mononucleares presentes na CLR foram isoladas utilizando centrifugação em gradiente de densidade (Ficoll-Paque ${ }^{\mathrm{TM}}$ PLUS, GE Healthcare, Buckinghamshire, Inglaterra, Reino Unido), conforme descrito abaixo.

\subsection{Obtenção de células mononucleares do sangue (CMS) e da CLR}

Para obtenção das células mononucleares do sangue, foram utilizados de 5 a $10 \mathrm{~mL}$ de sangue total coletado antes da doação. O sangue foi vertido em tubos cônicos de $50 \mathrm{~mL}$ para a separação com Ficoll-Paque ${ }^{\mathrm{TM}}$ PLUS, conforme descrito a seguir.

Inicialmente, as amostras de sangue foram diluídas em tampão fosfato-salina $\mathrm{pH} 7,4$ (PBS - Phosphate Buffered Saline) [1x] a fim de completar para volume final de $20 \mathrm{~mL}$. Esse sangue diluído foi então cuidadosamente colocado sobre $10 \mathrm{~mL}$ de Ficoll. Para as amostras provenientes da CLR, $2 \mathrm{~mL}$ da amostra foram diluídos em $8 \mathrm{~mL}$ de PBS [1x], e então colocados sobre $10 \mathrm{~mL}$ de Ficoll.

Ambas as amostras foram centrifugadas a $970 \mathrm{~g}$, por $30 \mathrm{~min}$ a $22{ }^{\circ} \mathrm{C}$. Após a centrifugação, a interface formada entre o gradiente de centrifugação (Ficoll) e o plasma foi cuidadosamente coletada com auxílio de pipeta pasteur e transferida para outro tubo cônico de $50 \mathrm{~mL}$. O volume do tubo foi completado com PBS [1x] para volume final de $50 \mathrm{~mL}$, e as amostras foram centrifugadas a $400 \mathrm{~g}$, por $10 \mathrm{~min}$ a $4{ }^{\circ} \mathrm{C}$. O sobrenadante foi descartado e o pellet das amostras de sangue foi ressuspendido em $1 \mathrm{~mL}$ de meio de cultura RPMI 1640 (Gibco ${ }^{\circledR}$ - Life Technology, Grand Island, Nova York, Estados Unidos) contendo 1\% de soro bovino fetal (SBF), enquanto que o pellet das amostras da CLR foi ressuspendido em $6 \mathrm{~mL}$ de meio de cultura RPMI 1640 contendo 1\% SBF. As células foram mantidas no gelo para as análises posteriores. 


\subsection{Viabilidade e contagem das células}

Para comparação das amostras de sangue e da CLR, a contagem das células foi feita em câmara de Neubauer (na proporção 1:10 de células e Tripan (v/v)) e a análise da viabilidade celular foi feita pela exclusão das células marcadas com azul de Tripan.

Para comparação de amostras de doadores frequentes e de $1^{\text {a }}$ vez, e para os ensaios funcionais a contagem de células foi realizada no contador automático de células Countess ${ }^{\circledR}$ Automated Cell Counter (Invitrogem ${ }^{\mathrm{TM}}$ - Life Technology, Grand Island, Nova York, Estados Unidos) e a análise da viabilidade celular foi feita pela exclusão das células marcadas com azul de Tripan.

\subsection{Anticorpos monoclonais}

Os anticorpos monoclonais foram previamente titulados para determinação das concentrações ideais de uso. Os clones dos anticorpos monoclonais utilizados estão descritos na Tabela 1:

Tabela 1 - Anticorpos e seus respectivos clones utilizados na imunofenotipagem das células por Citometria de Fluxo.

\begin{tabular}{ccc}
\hline Anticorpo & Clone & Empresa \\
\hline anti-CD3 & HIT3-A & BD* \\
anti-CD4 & RPA-T4 & BD* \\
anti-CD8 & HIT8-A & BD* \\
anti-CD19 & HIB19 & BD* \\
anti-CD14 & M-5E2 & BD* \\
anti-CD25 & M-A251 & BD* \\
anti-CD45 & 2 D1 & BD* \\
anti-CD45 & HI30 & Biolegend \\
anti-CD45RA & HI100 & BD* \\
anti-CD45RO & clone UCHL1 & BD* \\
anti-CD56 & B156 & BD* \\
anti-CD56 & HCD56 & Biolegend \\
anti-CD69 & FN50 & BD* \\
anti-CD122 & TU27 & BD* \\
anti-CD34 & 581 & BD* $^{*}$ \\
\hline
\end{tabular}

* Becton \& Dickinson Company@, BD 
Os anticorpos foram adquiridos conjugados com FITC, PE, PERCP-Cy5.5 ou APC. Para identificação e caracterização das populações celulares presente nas amostras, utilizamos os seguintes painéis (Tabela 2):

Tabela 2 - Painéis de anticorpos monoclonais utilizados para imunofenotipagem celular.

\begin{tabular}{ccccc}
\hline & FITC & PE & PerCP Cy 5.5 & APC \\
\cline { 2 - 5 } A & CD8 & CD3 & CD45 & CD4 \\
B & CD3 & CD56 & CD45 & CD19 \\
C & CD3 & CD56 & CD45 & CD14 \\
$\mathbf{D}$ & CD4 & CD69 & CD8 & CD19 \\
E & CD45RA & CD45RO & CD8 & CD4 \\
F & CD25 & CD122 & CD8 & CD4 \\
G & - & CD34 & CD45 & - \\
\hline
\end{tabular}

\subsection{Análise dos marcadores de superfície celular}

Após a contagem, as células foram transferidas para placa de cultura de 96 poços fundo $\mathrm{V}\left(5 \times 10^{5}\right.$ células/poço) e o volume completado para $170 \mu \mathrm{l}$, com tampão de marcação (PBS [1X]; 1\% de SBF e 0,05\% de azida sódica). Após centrifugação a $300 \mathrm{~g}$ por $5 \mathrm{~min}, 4{ }^{\circ} \mathrm{C}$, o sobrenadante foi descartado preservando o pellet. Ao pellet foram adicionados $170 \mu \mathrm{l}$ do tampão de marcação seguida de nova centrifugação a 300 g por $5 \mathrm{~min}, 4{ }^{\circ} \mathrm{C}$. O sobrenadante foi descartado e, em seguida, foi acrescentada a solução de anticorpos monoclonais previamente preparados (painéis descrito na Tabela 2), e incubados durante 30 min a $4{ }^{\circ} \mathrm{C}$, no escuro. Após este período, os poços foram lavados 2 vezes com $170 \mu \mathrm{l}$ de tampão de marcação e as amostras transferidas para tubos, contendo $300 \mu \mathrm{l}$ de tampão de marcação. As amostras foram analisadas no citômetro de fluxo BD LSRFortessa ${ }^{\mathrm{TM}}$ (Becton \& Dickinson Company@, BD, Nova Jersey, Nova York, Estados Unidos). A análise dos dados foi realizada com auxílio do software FlowJo Treestar@ versão 7.6.5. 


\subsection{Estratégias de análise para caracterização das populações de leucócitos nas amostras de sangue e da Câmara de Leucorredução}

Para identificação e caracterização das populações de linfócitos T e B, células NK, monócitos e o perfil de ativação dos linfócitos, foram utilizadas duas estratégias: uma envolvendo o marcador de linhagem hematopoética CD45, e outra na ausência desse marcador.

Para identificação das populações envolvendo o marcador CD45, foi realizada a exclusão de doublets utilizando os dados de FSC (do inglês Foward Scatter) considerando dados da altura e área do pulso elétrico gerado ao passar da célula pelo feixe de luz, (FSC-Hx FSC-A respectivamente) (Figura $3 \mathrm{~A}$ ), seguida da seleção das células $C D 45^{+}$, que foi realizada de acordo com a dispersão lateral da luz (SSC, do inglês Side Scatter) pela expressão do CD45 (SSC $\times$ CD45) (Figura 3B). Os eventos com tamanho e granulosidade (FSC $\times$ SSC) correspondente ao de linfócitos e monócitos foram então selecionados (Figura 3C). A partir dessa seleção, seguiu-se análise das populações de linfócitos $T$, linfócitos $B$, monócitos, e células NK (Figuras 4-6).

Para as populações em que o marcador de linhagem hematopoética CD45 não foi utilizado, os doublets também foram excluídos (FSC-H x FSC-A; Figura 3D) e, baseados na distribuição de eventos por tamanho e granulosidade (FSC x SSC), os eventos compatíveis com características de linfócitos e monócitos foram selecionados (Figura 3E); ainda baseado na distribuição de eventos por tamanho e granulosidade (FSC x SSC), foi feito uma seleção de eventos na região dos linfócitos (Figura 3F). A partir dessa estratégia, se seguiu a análise do perfil de ativação dos linfócitos T e B detalhada a seguir (Figuras 7-9). 
Figura 3 - Estratégias para caracterização das populações leucocitárias a partir da utilização do marcador de linhagem hematopoética CD45 (A-C) e na ausência do mesmo (D-F).
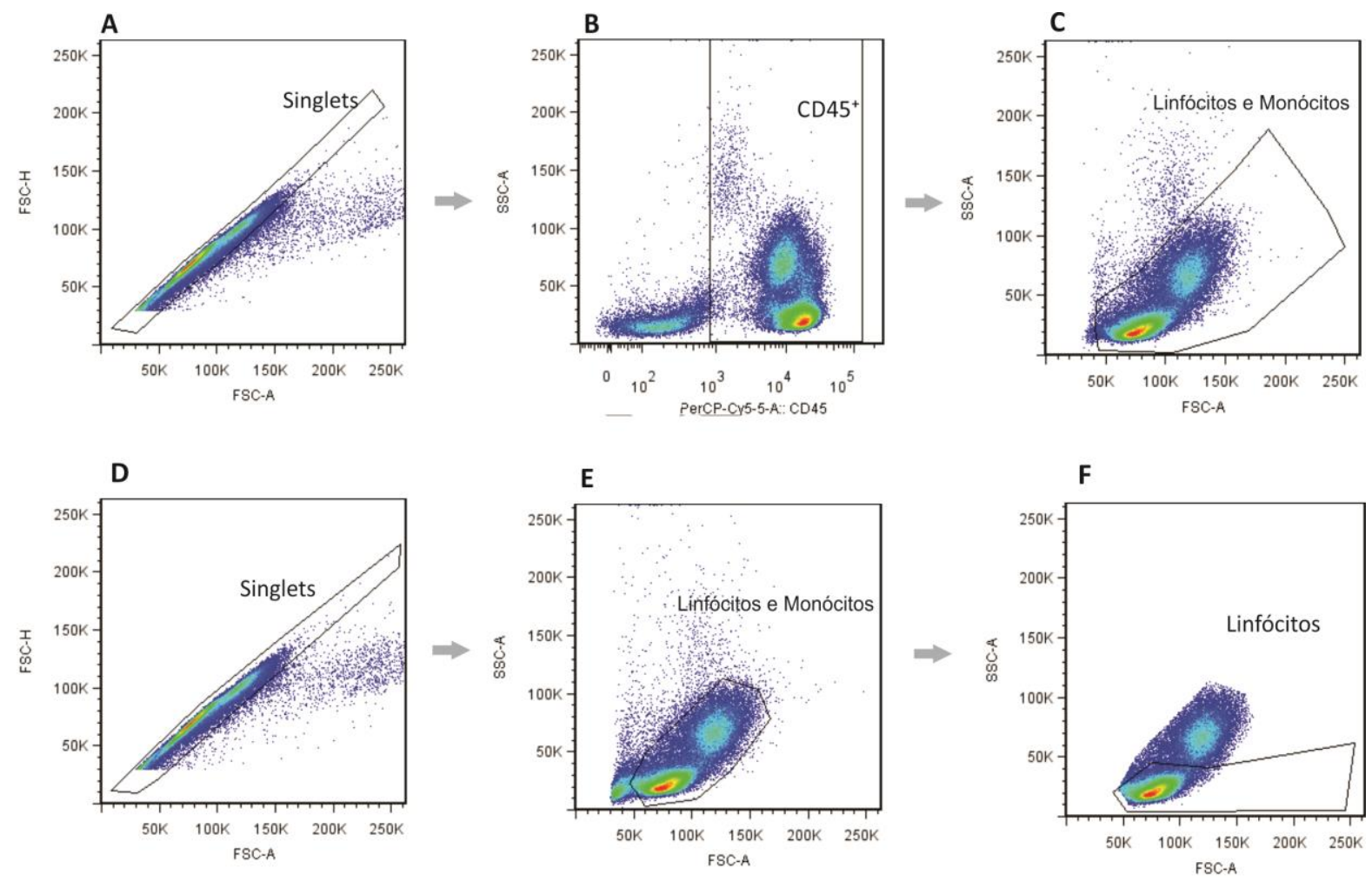

(A e D) Seleção de singlets a partir da dispersão de eventos por FSC-H x FSC-A. (B) Seleção das células $C D 45^{+}$e; (C e E) Seleção de área correspondente aos linfócitos e monócitos a partir da análise de dispersão de eventos por SSC x FSC; (F) seleção da área correspondente aos linfócitos (SSC x FSC). Análise representativa de uma amostra de sangue.

Para caracterizar as populações de linfócitos $\mathrm{T}_{1} \mathrm{TCD}^{+}$e $\mathrm{TCD} 8^{+}$, foram selecionadas as células $\mathrm{CD}_{4}{ }^{+} \mathrm{CD}^{+}$(Figura $4 \mathrm{~A}$ ), dentro da janela dos linfócitos e monócitos (Figura 3C).

Com base na distribuição de tamanho por granulosidade (FSC $\times$ SSC), os linfócitos foram selecionados (Figura 4B). As populações de linfócitos $T$ foram caracterizadas por serem $\mathrm{CD}_{4} 5^{+} \mathrm{CD}^{+} \mathrm{CD} 4^{+} \mathrm{CD} 8^{-}$ou $\mathrm{CD}_{4} 5^{+} \mathrm{CD} 3^{+} \mathrm{CD} 4^{-} \mathrm{CD} 8^{+}$(Figura $4 \mathrm{C}$ ).

Com o objetivo de caracterizar os linfócitos $B$, foi considerada a expressão de CD3 e CD19. Após a seleção de eventos $\mathrm{CD}^{+} 5^{+}$de linfócitos e monócitos (Figura 3), foi avaliada a expressão de $C D 3$ e CD19. As regiões que contemplavam as células $C D 19^{-} \mathrm{CD}^{+}, \mathrm{CD}^{+} 9^{+} \mathrm{CD}^{-} \mathrm{e}^{-}$ $\mathrm{CD}^{\circ}{ }^{\circ} \mathrm{CD}^{-}{ }^{-}$foram selecionadas (Figura 5). 
Figura 4 - Caracterização dos linfócitos T.
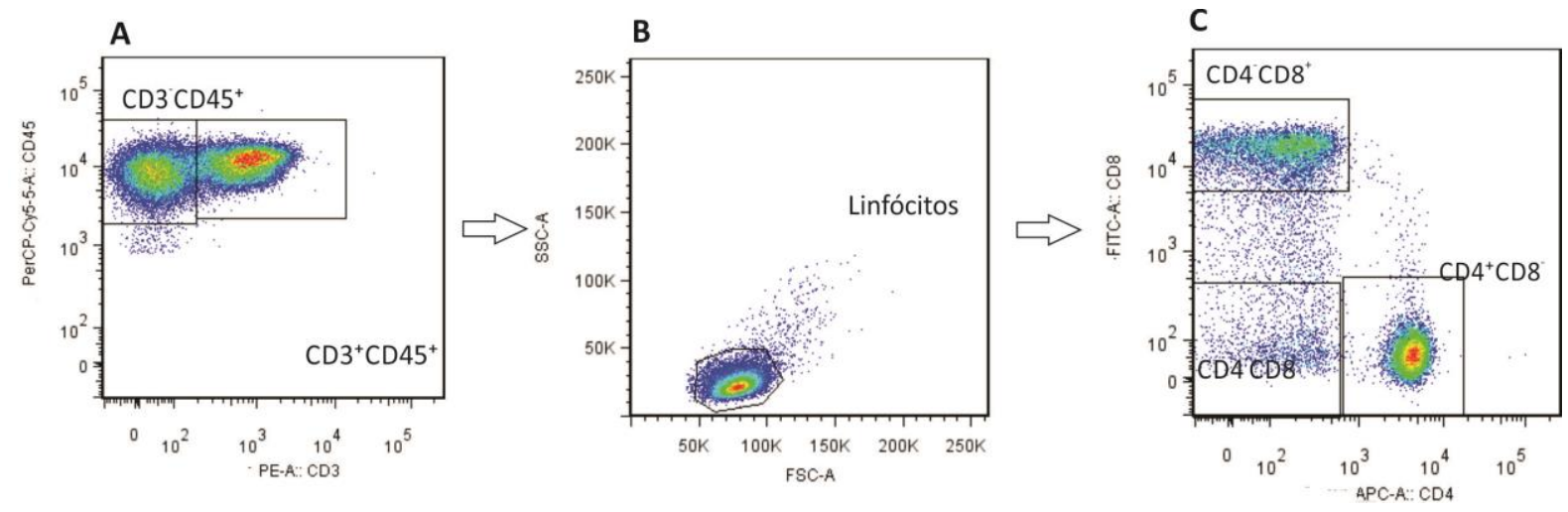

A caracterização foi baseada na expressão de CD3 e CD45 (A), tamanho e granulosidade (B); expressão de CD4 e CD8 (C). Análise representativa de uma amostra de sangue.

Figura 5 - Caracterização de linfócitos B.
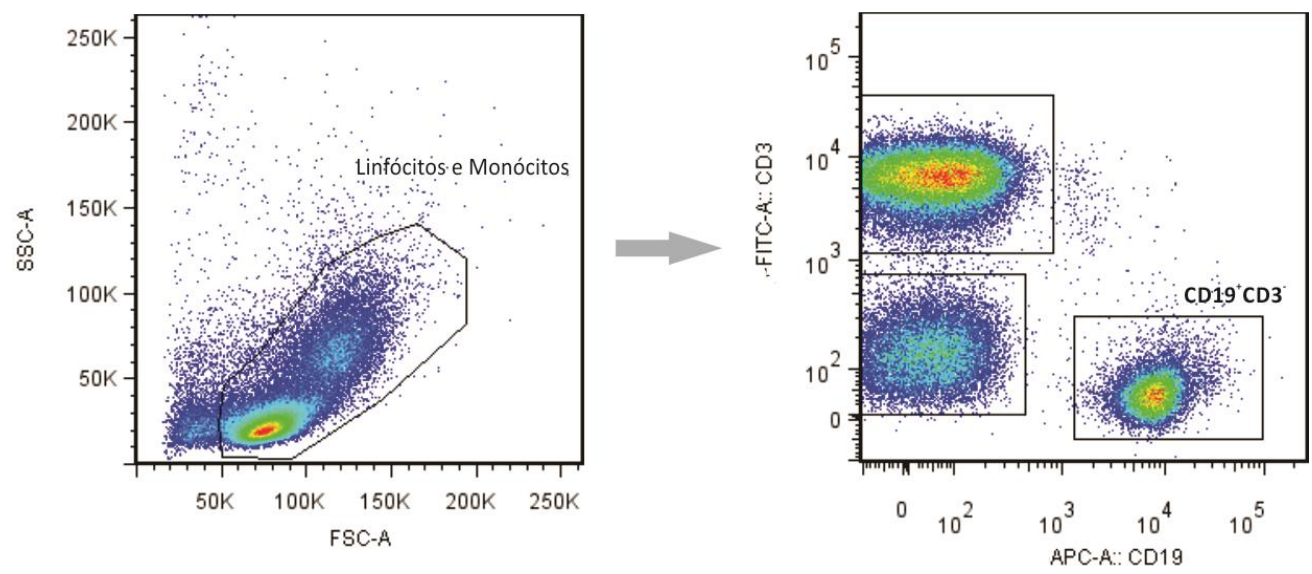

Identificação dos eventos com características dos linfócitos e monócitos baseados em tamanho e granulosidade (FSC $\times$ SSC) e posterior seleção dos linfócitos B $\left(C D 19^{+} C^{-} 3^{-}\right)$. Análise representativa de uma amostra de sangue.

Para a caracterização dos monócitos, após a seleção dos linfócitos e monócitos (Figura 3) populações CD14 ${ }^{+}$e CD14 foram selecionadas baseadas também na expressão de CD3. Dessa forma foram identificadas três populações: $\mathrm{CD}^{-} \mathrm{CD} 14^{+}, \mathrm{CD}^{-} \mathrm{CD} 14^{-}$e $\mathrm{CD}^{+} \mathrm{CD} 14^{-}$ (Figura 6). A população $\mathrm{CD}^{-} \mathrm{CD} 14^{+}$foi considerada correspondente a de monócitos. Devido à presença do marcador CD56, esse painel também foi utilizado para a identificação de células NK. Para tanto, foi feito uma seleção na população $\operatorname{CD}^{-}{ }^{-} \mathrm{CD} 14^{-}$e, baseado na expressão de CD56 e CD45, as células NK foram identificadas como sendo $\mathrm{CD}^{-1} 5^{+} \mathrm{CD}^{-} \mathrm{CD} 14^{-} \mathrm{CD} 56^{+}$. Entre as células $\mathrm{CD} 6^{+}$, foi possível notar uma população com fluorescência mais alta; tal população foi considerada $C D 45^{+} \mathrm{CD} 56^{\text {bright }}$. Dentre a população $\mathrm{CD}^{+} \mathrm{CD} 14^{-}$, ainda foi possível indicar 
uma população $\mathrm{CD}^{+} \mathrm{CD} 6^{+}$. Por ser duplo positiva para a expressão de $\mathrm{CD} 3$ e CD56, essa população poderia ser considerada como células NKT; no entanto, outros marcadores são necessários para melhor caracterização dessa população.

Figura 6 - Caracterização de monócitos e células NK.
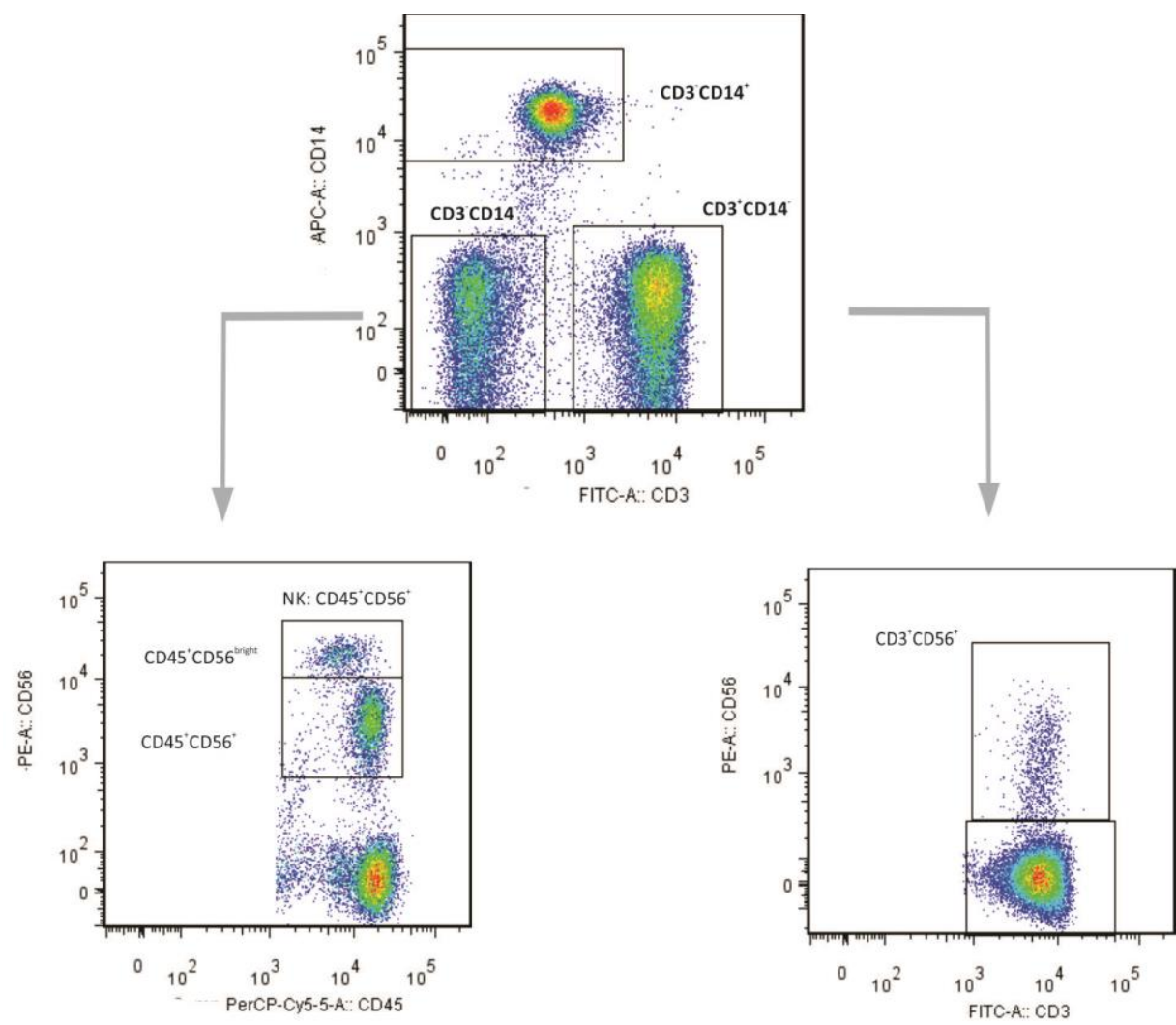

Os monócitos foram identificados segundo a expressão de $\mathrm{CD} 3$ e $\mathrm{CD} 14$, sendo caracterizados como $\mathrm{CD}^{-} \mathrm{CD} 14^{+}$ dentro do gate de linfócitos e monócitos. A caracterização das células NK foi realizada de acordo com a expressão de $\mathrm{CD} 56$ e $\mathrm{CD} 45$, apresentando fenótipo como $\mathrm{CD}_{45}{ }^{+} \mathrm{CD} 3^{-} \mathrm{CD} 56^{+}$dentro do gate $\mathrm{CD} 3^{-} \mathrm{CD} 14^{-}$. Dentre as células NK foi identificada uma população $\mathrm{CD} 45^{+} \mathrm{CD} 56^{\text {bright }}$. Identificação de população celular $\mathrm{CD} 3^{+} \mathrm{CD} 56^{+}$, dentro do gate $\mathrm{CD}^{+} \mathrm{CD} 14^{-}$. Análise representativa de uma amostra de sangue.

Com o objetivo de avaliar o estado de ativação linfócitos, foram analisadas a expressão do marcador de ativação precoce (CD69) em linfócitos T e B, e a expressão das moléculas CD25 e CD122 (correspondente às cadeias alfa e beta do receptor de IL-2, respectivamente) em linfócitos T. Também foi avaliada a expressão de CD45RA e CD45RO a fim de analisar se as células recuperadas sugerem um perfil de células naïves ou de memória.

Para a análise da expressão de CD69 realizamos a discriminação de doublets e a seleção da janela dos linfócitos, conforme ilustrado na Figura 3D-F. Dentro do gate dos 
linfócitos e baseado na expressão de CD4 e CD8, foram selecionadas três populações principais: $\mathrm{CD}^{+} \mathrm{CD}^{-}, \mathrm{CD}^{-} \mathrm{CD} 8^{+}$e $\mathrm{CD}^{-} \mathrm{CD} 8^{-}$. A expressão de $\mathrm{CD} 69$ foi analisada diretamente dentro das populações simples positiva. Já dentro da população duplo-negativa a expressão de CD19 e CD69 foi analisada de forma simultânea, dessa forma, foi possível avaliar a expressão de CD69 nos linfócitos T e B (Figura 7).

Figura 7 - Estratégia para identificação e análise da expressão do marcador precoce de ativação CD69 em linfócitos T e B.
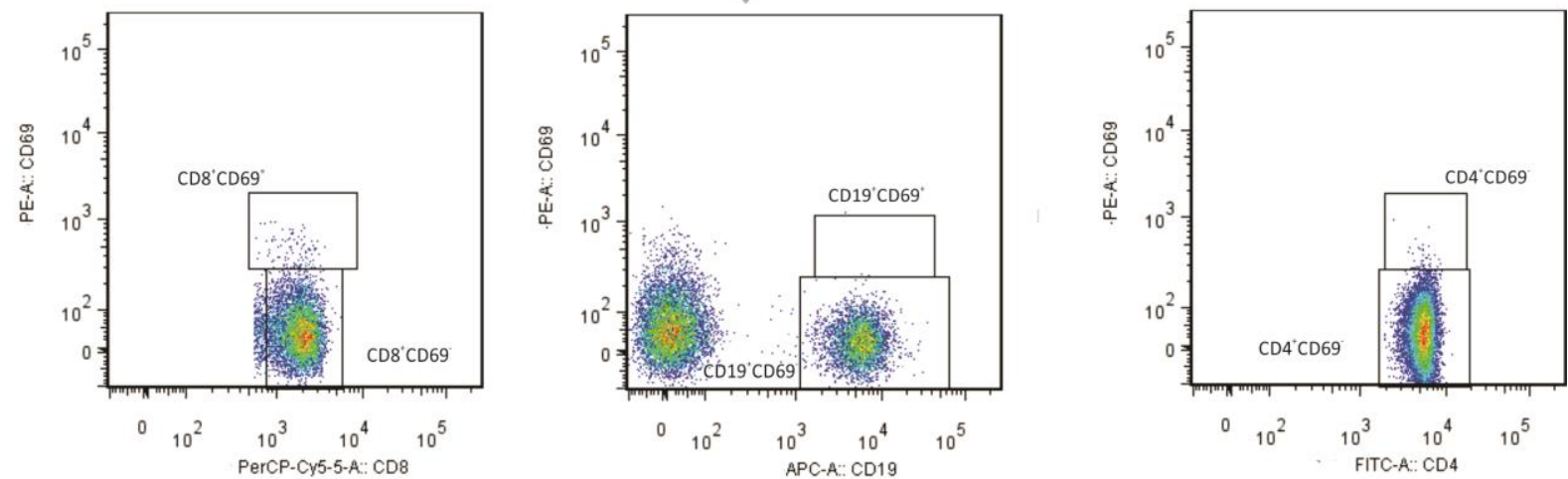

Identificação de linfócitos $\mathrm{T}^{\mathrm{CD}} 4^{+} \mathrm{CD} 8^{-}, \mathrm{CD}^{-} \mathrm{CD} 8^{+}$e $\mathrm{CD} 4^{-} \mathrm{CD} 8^{-}$seguida da análise da expressão de $\mathrm{CD} 69$ em populações de linfócitos $T C D 4^{+} C D 8^{-}$e $C D 4^{-} C D 8^{+}$. Análise da expressão de $C D 69$ em populações de linfócitos $B$ caracterizados como $\mathrm{CD} 4^{-} \mathrm{CD} 8^{-} \mathrm{CD} 19^{+}$. Análise representativa de uma amostra de sangue.

Após a ativação inicial, os linfócitos passam a expressar outros receptores, mais tardios, como o caso do receptor de alta afinidade para IL-2, que é expresso em células T convencionais ativadas e células $T$ reguladoras. $\mathrm{O}$ receptor da IL-2 é composto por três cadeias, sendo a cadeia alfa (CD25), beta (CD122) e gama comum (CD132). As cadeias beta e gama comum estão expressas nos linfócitos e após, a ativação, a cadeia alfa passa a ser expressa, formando o receptor de IL-2 de alta afinidade (61). 
Com o objetivo de verificar também o perfil de ativação das células recuperadas da CLR e compará-las com as células do sangue, a expressão do receptor para IL-2 (CD122 e CD25) foi estudada. Para tanto, a primeira etapa da estratégia se seguiu como exemplificado na Figura 3D-F. A partir da seleção na região correspondente aos linfócitos, populações $\mathrm{CD}^{+} \mathrm{CD} 8^{-}$e $\mathrm{CD} 4^{-} \mathrm{CD} 8^{+}$foram selecionadas baseadas na expressão desses marcadores. Em cada população simples-positiva foi observada a expressão das proteínas CD122 e CD25 (Figura 8).

Figura 8 - Estratégia para análise da expressão do receptor de IL-2 (CD122 e CD25) em linfócitos T.
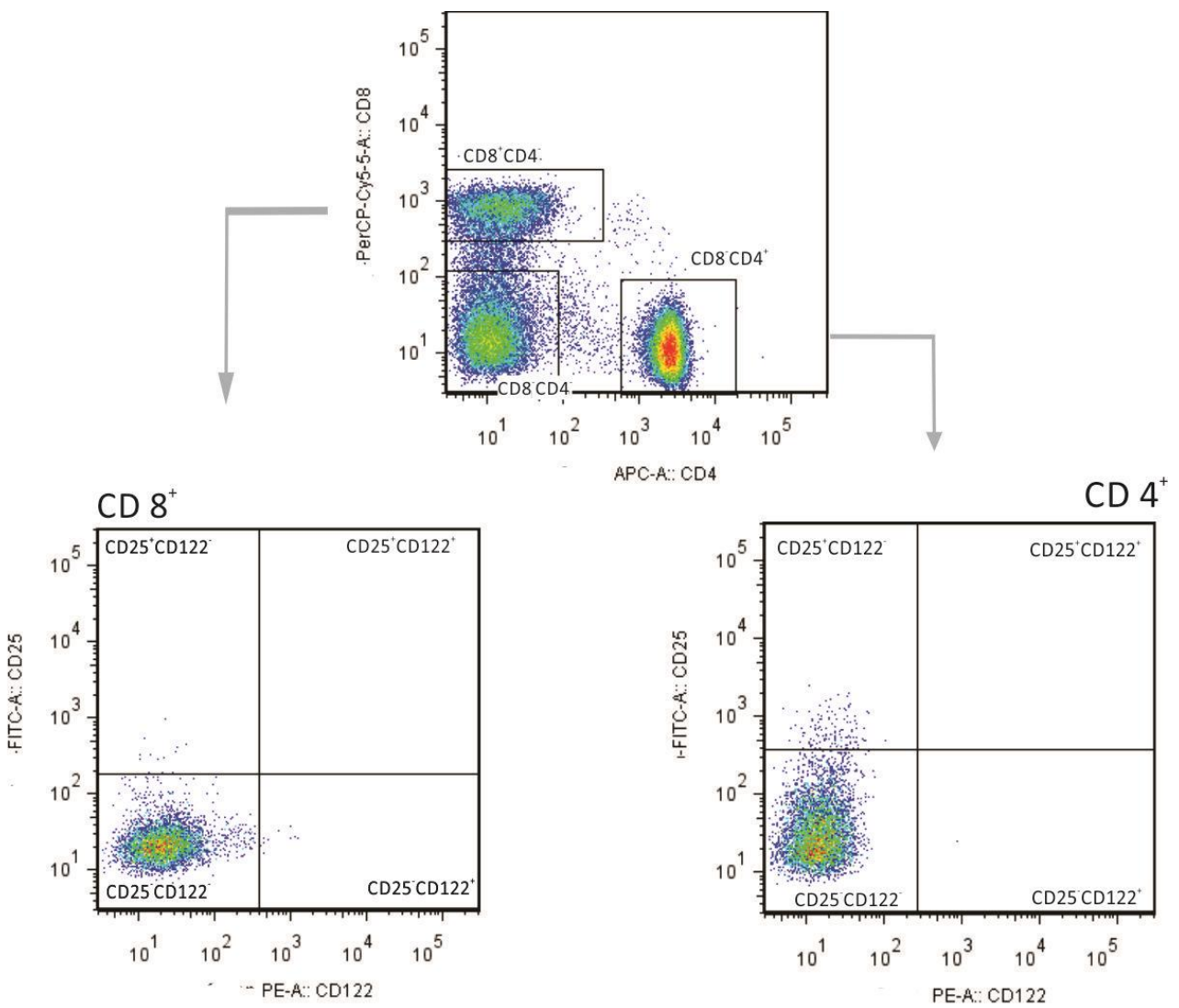

Identificação das populações de linfócitos T simples positivas ( $\mathrm{T} \mathrm{CD4} 4^{+}$e $\mathrm{T} \mathrm{CD8^{+ }}$ ) seguida da análise da expressão de $\mathrm{CD} 122$ e $\mathrm{CD} 25$ em populações de linfócitos $\mathrm{T} \mathrm{CD}^{+}$e $\mathrm{T} \mathrm{CD} 8^{+}$. Análise representativa de uma amostra de sangue.

A fim de avaliar a frequência de células com características de naïve e de memória, analisamos a expressão de das proteínas CD45RA e CD45RO em linfócitos T. Após a seleção dos linfócitos (Figura 3), com base na expressão de CD4 e CD8, foram identificadas populações $\mathrm{CD}^{+} \mathrm{CD} 8^{-}, \mathrm{CD}^{-} \mathrm{CD} 8^{+}$. Em cada população de linfócitos $\mathrm{T}\left(\mathrm{CD} 4^{+}\right.$e $\mathrm{CD} 8^{+}$) foi analisada a expressão de CD45RA e CD45RO (Figura 9). 
Figura 9 - Estratégia para análise da expressão de CD45RA e CD45RO em linfócitos T.



Identificação das populações de linfócitos $\mathrm{T} \mathrm{CD4}^{+}$e $\mathrm{T} \mathrm{CD} 8^{+}$, seguida da análise da expressão de $\mathrm{CD} 45 \mathrm{RA}$ e CD45RO em linfócitos $\mathrm{T} \mathrm{CD}^{+} \mathrm{CD} 8^{-}$e $\mathrm{CD} 4^{-} \mathrm{CD} 8^{+}$. Análise representativa de uma amostra de sangue.

\subsection{Ensaio de Proliferação Celular}

Os ensaios de proliferação celular foram realizados com marcação de CFSE (do inglês Carboxyfluorescein succinimidyl ester).

Após a separação e contagem das células mononucleares de amostras de sangue e da CLR, foram separadas $10 \times 10^{6}$ células em tubos cônicos de $15 \mathrm{~mL}$. O volume foi completado para $10 \mathrm{~mL}$ com PBS e as amostras centrifugadas a $400 \mathrm{~g}$ por $10 \mathrm{~min}$ a $4{ }^{\circ} \mathrm{C}$. Após a centrifugação o sobrenadante foi descartado e o pellet ressuspendido em $1 \mathrm{~mL}$ de CFSE 1 $\mu \mathrm{M}$ (diluído em PBS). As amostras foram incubadas a $37{ }^{\circ} \mathrm{C}$ por $10 \mathrm{~min}$ em banho-maria. Após o período de incubação, foram adicionados $9 \mathrm{~mL}$ de PBS $10 \%$ SBF e realizou-se nova centrifugação a $400 \mathrm{~g}$ por $10 \mathrm{~min}$ a $4{ }^{\circ} \mathrm{C}$. O sobrenadante foi descartado e ao pellet adicionou-se $10 \mathrm{~mL}$ de PBS $10 \% \mathrm{SBF}$, seguida de outra incubação a $37{ }^{\circ} \mathrm{C}$ por $15 \mathrm{~min}$ em banho-maria. As amostras foram centrifugadas novamente a $400 \mathrm{~g}$ por $10 \mathrm{~min}$ a $4{ }^{\circ} \mathrm{C}$, o 
sobrenadante foi descartado e o pellet ressuspendido com meio de cultura RPMI 1640 completo, a fim de obter a concentração de $4 \times 10^{6} \mathrm{cel} / \mathrm{mL}$.

A fim de observar a capacidade proliferativa das células e a responsividade das mesmas frente a diferentes intensidades de estímulos, utilizamos duas concentrações de PHA (Phytohaemagglutini, Gibco ${ }^{\mathrm{TM}}$ ), previamente estabelecidas, para induzir alta e baixa proliferação.

As células foram transferidas para placa de cultura de 96 poços, fundo chato $(0,4 \mathrm{x}$ $10^{6}$ cels), contendo meio de cultura RPMI completo (controle não estimulado); adicionalmente, como controle positivo, foi utilizado 0,125 $\mu \mathrm{l} /$ poço e 0,5 $\mu \mathrm{l} /$ poço de $\mathrm{PHA}$ diluído em meio de cultura RPMI completo. As células foram então mantidas em estufa em $10 \%$ de $\mathrm{CO}_{2}$ a $37^{\circ} \mathrm{C}$ por $72 \mathrm{~h}$.

Após o período de incubação, as células foram transferias para placas de fundo $\mathrm{V}$ e foi realizada a marcação com anticorpos conforme descrito no item 3.6. Os anticorpos utilizados foram CD4 PE (clone RPA-T4) e CD8 PerCP Cy 5.5 (clone HIT8-A).

As amostras foram analisadas no citômetro de fluxo BD LSRFortessa ${ }^{\mathrm{TM}}$ (Becton \& Dickinson Company (C, BD). A análise dos dados foi realizada com auxílio do software FlowJo Treestar@ versão 7.6.5.

\subsection{Apoptose espontânea}

Para os testes de apoptose espontânea foram utilizadas amostras de sangue e da CLR de doadores esporádicos, com mais de uma doação de plaquetas por aférese.

Foi analisada a apoptose em três momentos: $0 \mathrm{~h}, 2 \mathrm{~h}$ e $6 \mathrm{~h}$. $\mathrm{O}$ tempo zero corresponde àquelas células mononucleares que foram isoladas e imediatamente imunofenotipadas e analisadas quanto à expressão de Anexina-V (BD Pharmigen ${ }^{\mathrm{TM}}$ ). Para cultura de $2 \mathrm{~h}$ e $6 \mathrm{~h}$, $1 \times 10^{6}$ células foram transferidas para placa de 96 poços fundo chato contendo meio de cultura RPMI completo (volume total de $200 \mu \mathrm{l} /$ poço), e mantidas em estufa, em $10 \%$ de $\mathrm{CO}_{2}$ a $37^{\circ} \mathrm{C}$, pelos tempos estipulados. As células não receberam nenhum tipo de estímulo.

Nos períodos determinados, as células $\left(1 \times 10^{6}\right.$ no tempo $\left.0 h\right)$ foram transferidas para placa de fundo $\mathrm{V}$ e centrifugadas $300 \mathrm{~g}$ por $5 \mathrm{~min}, 4^{\circ} \mathrm{C}$. O sobrenadante foi descartado e o pellet ressuspendido $170 \mu \mathrm{l}$ de tampão de marcação, passando por uma nova centrifugação a $300 \mathrm{~g}$ por $5 \mathrm{~min}, 4^{\circ} \mathrm{C}$. O sobrenadante foi descartado e o pellet ressuspendido no mix de 
anticorpos, previamente preparado, contendo anti-CD19 FITC (clone HIB19), anti-CD4 PE (clone RPA-T4) e anti-CD8 PerCP 5.5 (clone RPA-T8) e incubado no escuro por 30 minutos a 4 ${ }^{\circ} \mathrm{C}$. Após esse período, as células foram lavadas em ressupendidas com $50 \mu \mathrm{l}$ de tampão de Anexina-V [1x] (BD Pharmigen ${ }^{\mathrm{TM}}$ ) e $1 \mu \mathrm{l}$ de Anexina-V APC. As células foram incubadas por 20 minutos no escuro à temperatura ambiente. Após esse período as células foram transferidas para tubos de citometria contendo $350 \mu \mathrm{l}$ de tampão de Anexina-V. As mostras foram analisadas por Citometria de Fluxo no citômetro BD LSRFortessa ${ }^{\mathrm{TM}}$ (Becton \& Dickinson Company(C, BD). A análise dos dados foi realizada com auxílio do software FlowJo Treestar@ versão 7.6.5.

Para cada tempo estudado, amostras de sangue e da CLR foram marcadas somente com anticorpos, sem Anexina-V, para estabelecer o gate em que as células passam a expressar a mesma. Primeiramente foi feita a seleção de singlets, seguida da seleção de linfócitos, de acordo com o tamanho e granulosidade, e posterior seleção de células $\mathrm{CD} 4^{+}$, $\mathrm{CD}^{+}$e CD4 ${ }^{-} \mathrm{CD} 8^{-}$. Das células duplo-negativas, foram selecionadas as células $\mathrm{CD}^{+}{ }^{+}$(Figura 10A). Após a identificação das populações simples positivas, foi analisada a expressão de Anexina-V para linfócito T CD4 (Figura 10B), T CD8 (Figura10C) e linfócito B (Figura 10D).

Figura 10 - Estratégia de identificação de linfócitos T e B apoptóticas (Anexina-V+).
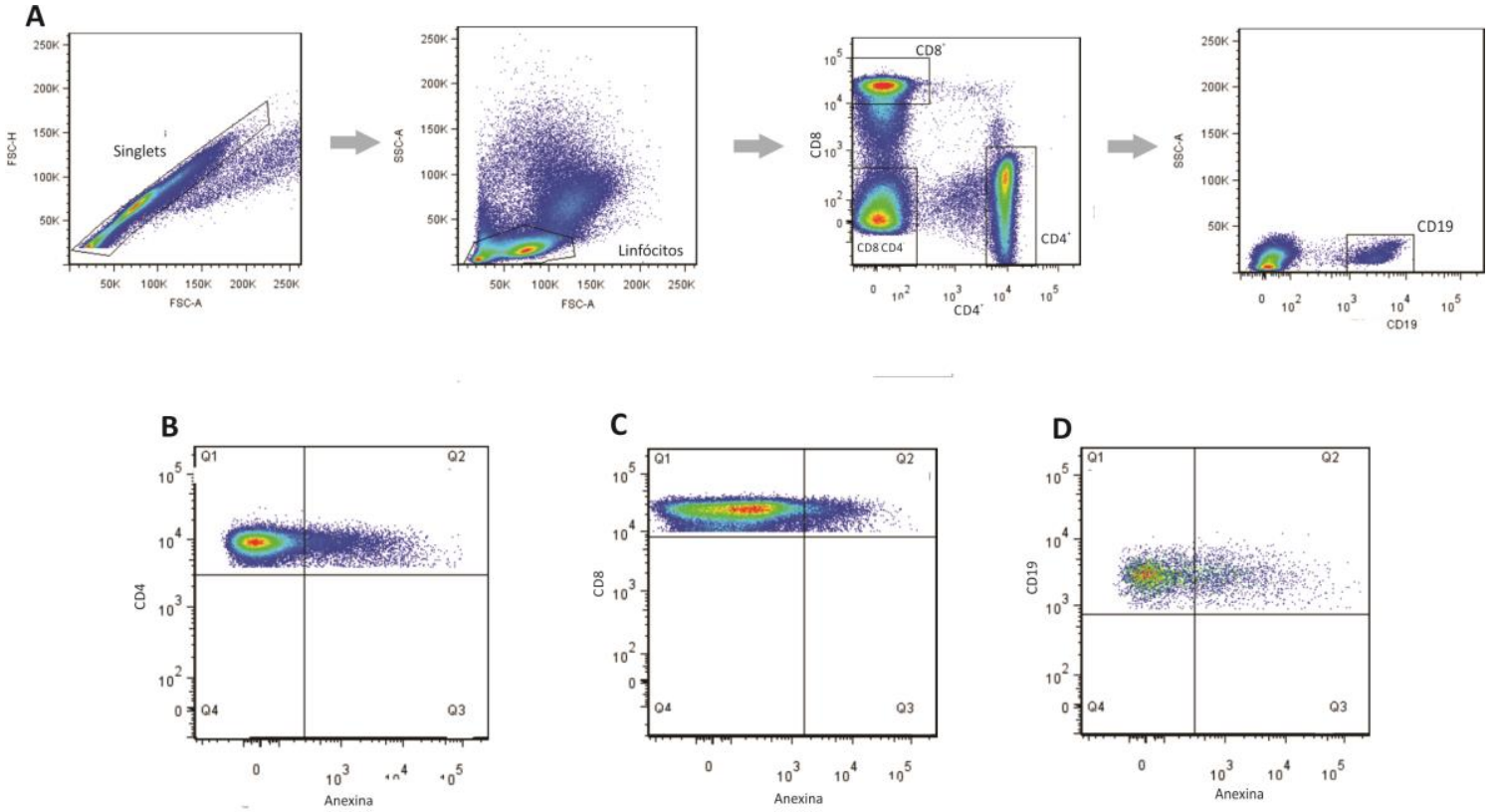

(A) Seleção de singlets, seguida da seleção de linfócitos e posterior seleção de células $\mathrm{CD}^{+}, \mathrm{CD}^{+}$e $\mathrm{CD} 44^{-} \mathrm{CD} 8$ (B) Células $\mathrm{CD}^{+}$Anexina- $\mathrm{V}^{+}$; (C) Células $\mathrm{CD}^{+}$Anexina- $\mathrm{V}^{+}$; (D) Células $\mathrm{CD} 19^{+}$Anexina- $\mathrm{V}^{+}$. 


\subsection{Produção de citocinas}

Para análise da produção de citocinas as células $\left(10^{6}\right.$ cels) provenientes de amostras de sangue e da CLR foram mantidas em cultura com meio RPMI completo, em placas de fundo chato, com (PHA 0,5 e PHA 0,125 $\mu \mathrm{l} /$ poço) ou sem (controle negativo) estímulo por $48 \mathrm{~h}$ em estufa em $10 \%$ de $\mathrm{CO}_{2}$ a $37{ }^{\circ} \mathrm{C}$. Após esse período o sobrenadante foi coletado e congelado a $-80^{\circ} \mathrm{C}$ para uso posterior.

A análise da produção de citocinas foi realizadas com o kit BD ${ }^{\mathrm{TM}}$ Cytometric Bead Array (CBA) Human Th1/Th2/Th17 (Becton \& Dickinson CompanyC, BD) conforme a orientação do fabricante. Foi analisada a produção das seguintes citocinas: IL-17A, IFNTNF; IL-10; IL-6; IL-4 e IL-2. As amostras foram lidas no citômetro de fluxo FACS Aria II (BD, Bioscience) e analisadas no software FCAP Array 3.0. Os resultados são apresentados em $\mathrm{pg} / \mathrm{mL}$.

\subsection{Identificação das Células-tronco hematopoéticas}

As $\mathrm{CTH}$ foram caracterizadas como $\mathrm{CD} 34^{+} \mathrm{CD} 45^{\text {low }}$. Dado que a glicoproteína $\mathrm{CD} 34$ não é expressa somente em CTH, a marcação simultânea com CD45 restringe a seleção das células $\mathrm{CD}_{3} 4^{+}$à linhagem hematopoética. A estratégia para identificação dessa população está ilustrada na Figura 11. Foi realizada a exclusão de doublets, seguida pela seleção das células que expressam o marcador leucocitário CD45. Entre as células $C D 45^{+}$, de acordo com a distribuição por tamanho e granulosidade (FSC x SSC), foram selecionadas as células com características de linfócitos e monócitos. Dentre essas células, foram selecionadas as células $\mathrm{CD}^{+} 4^{+}$, seguida pela seleção da baixa expressão de CD45. 
Figura 11 - Caracterização das Células-tronco hematopoéticas (CTH) $\left(\mathrm{CD} 34^{+} \mathrm{CD} 45^{\text {low }}\right)$.
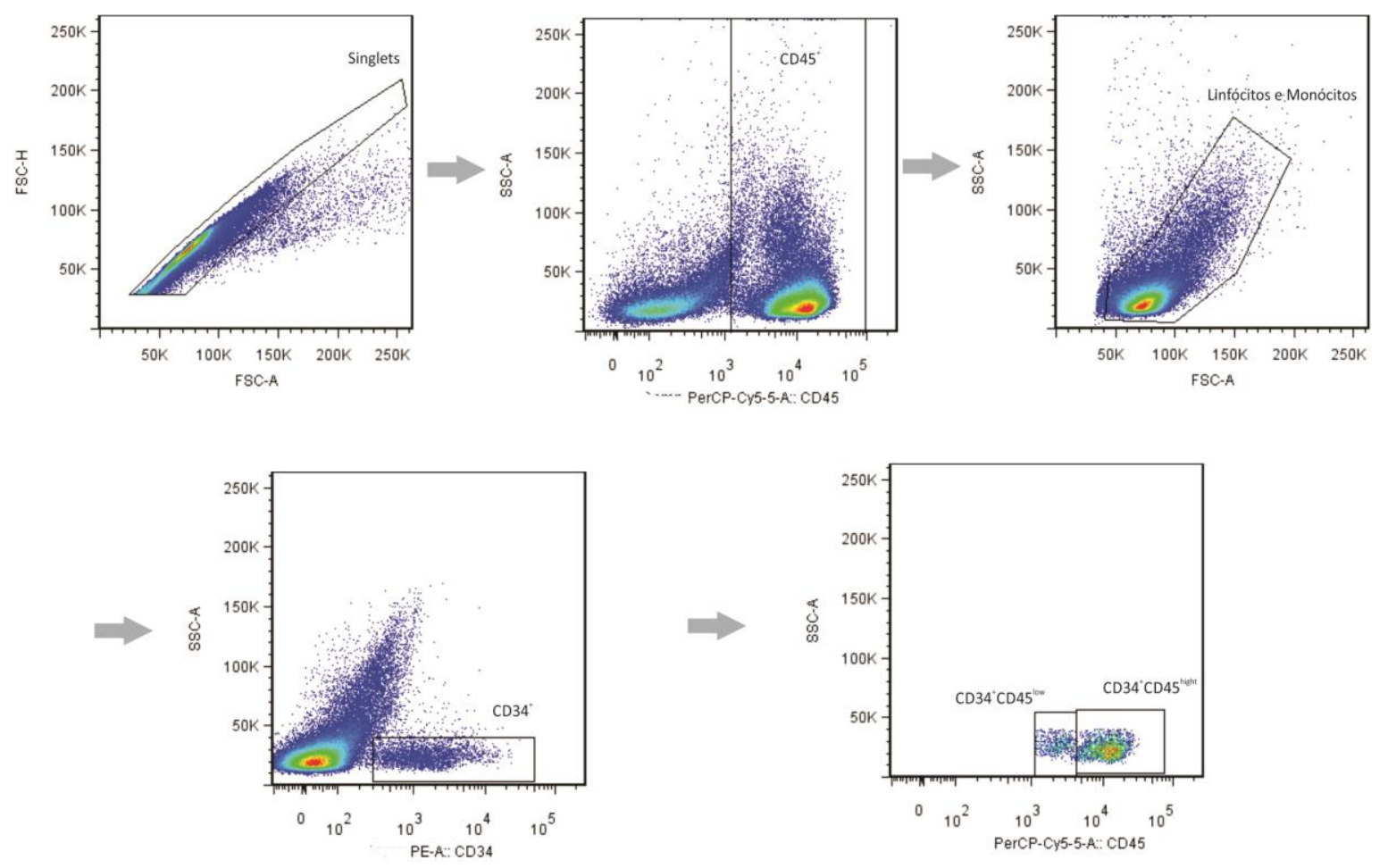

Exclusão de doublets pelas características de FSC-A x FSC-H seguido da seleção dos leucócitos pela expressão de CD45. A seleção dos linfócitos e monócitos foi realizada de acordo com as características de tamanho e granulosidade (FSC $\times$ SSC). Então se deu a identificação das células $\mathrm{CD}_{3} 4^{+}$e seleção das células-tronco hematopoéticas ( $C D 34^{+} \mathrm{CD} 45^{\text {low }}$ ). Análise representativa de uma amostra de sangue

\subsection{Análise comparativa de doadores de plaquetas frequentes e de $1 \underline{a}$ vez}

Segundo a portaria 1353 do Ministério de Saúde (14.06.2011), é considerado doador de repetição todo aquele doador que realizou duas ou mais doações no período de 12 meses, e o doador de $1^{\text {a }}$ vez é todo doador que doa pela primeira vez naquele serviço de hemoterapia. A fim de comparar doadores de plaqueta frequente com doadores de 1a vez, neste estudo, foi considerado doador frequentes aquele indivíduo que realizou pelo menos 6 doações de plaquetas nos últimos 12 meses (incluindo a doação realizada para participação do projeto). Foi aceito como doadores de primeira vez, aquele doador que cuja doação de plaqueta era a primeira a ser realizada. Caso já tivesse doações anteriores de plaquetas em outros hemocentros, para esse estudo o doador não foi considerado como de 1a vez.

Desses doadores foi coletado de 5 a $10 \mathrm{~mL}$ de sangue, que foram processados conforme os itens 3.3, 3.5 e 3.6. Foram comparados somente amostras de sangue em 
relação ao número total de células, baseados no hemograma fornecido pelo banco de sangue.

\subsection{Análise estatística}

Para comparação do número total de células entre sangue e CLR foi realizado o teste de Wilcoxon. Nas análises do número total entre doadores frequentes e de 1 a vez foi realizado teste de Mann-Whitney. Os resultados foram apresentados em mediana e intervalo interquartil [IIQ]. A significância estatística foi estabelecida para $p<0,05$, para todos os testes. As análises foram realizadas com o software GraphPad Prism 5.0. 


\section{RESULTADOS}

\subsection{Doadores}

Os doadores participantes do trabalho foram homens, com peso entre 65 e $138 \mathrm{Kg}$, altura entre 164 e $196 \mathrm{~cm}$, e idade entre 26 e 72 anos (Tabela 3). Ao todo, 52 doadores participaram do trabalho, sendo que as amostras obtidas foram utilizadas na análise comparativa entre amostras de sangue e da Câmara de Leucorredução de mesmo doador e para os ensaios funcionais de proliferação e morte celular. Algumas amostras utilizadas nas comparações, ocasionalmente também podem ter sido utilizadas na realização dos ensaios funcionais.

\subsection{Análise do rendimento celular obtido.}

Para 27 das amostras coletadas, o rendimento celular da CLR foi comparado com o rendimento obtido de amostras de sangue de mesmo doador.

O volume total de amostra obtido da CLR variou entre 2,5 e $12,4 \mathrm{~mL}$, sendo a mediana de amostra de $9 \mathrm{~mL}$ enquanto que o volume das amostras de sangue total coletadas variou entre 6 e 9,5 mL. Para cada doação, o tipo de produto coletado, a duração da doação, a volemia de cada doador e o volume de plaqueta coletada foi mensurada pela equipe do Banco de Sangue (Tabela 4). Esses dados foram comparados com o rendimento celular total (obtido após o isolamento das CMS) proveniente das amostras de sangue da CLR a fim de avaliar a possível correlação entre algum desses fatores. A análise estatística mostrou apenas correlação entre o produto coletado (se plaqueta simples ou duplas) com o rendimento da CLR. Para nenhuma das outras varáveis foi observada qualquer correlação. As variáveis como idade, peso, altura, contagem total de leucócitos e número de doações no último ano também foram avaliadas a fim de encontrar correlação com o rendimento da CLR, porém nenhuma correlação foi encontrada (APÊNDICE B). 
Tabela 3 - Dados demográficos dos doadores de plaquetas por aférese.

\begin{tabular}{|c|c|c|c|}
\hline Doador & Idade & Peso & Altura \\
\hline 1 & 37 & 94 & 1,81 \\
\hline 2 & 36 & 110 & 1,96 \\
\hline 3 & 50 & 92 & 1,74 \\
\hline 4 & 37 & 76 & 1,83 \\
\hline 5 & 46 & 93 & 1,83 \\
\hline 6 & 31 & 65 & 1,78 \\
\hline 7 & 40 & 93 & 1,76 \\
\hline 8 & 56 & 92 & 1,8 \\
\hline 9 & 72 & 85 & 1,74 \\
\hline 10 & 41 & 87 & 1,83 \\
\hline 11 & 31 & 72 & 1,79 \\
\hline 12 & 41 & 138 & 1,87 \\
\hline 13 & 26 & 78 & 1,83 \\
\hline 14 & 52 & 113 & 1,77 \\
\hline 15 & 33 & 90 & 1,81 \\
\hline 16 & 47 & 93 & 1,69 \\
\hline 17 & 43 & 68 & 1,69 \\
\hline 18 & 34 & 84 & 1,76 \\
\hline 19 & 64 & 70 & 1,73 \\
\hline 20 & 43 & 91 & 1,8 \\
\hline 21 & 38 & 94 & 1,88 \\
\hline 22 & 61 & 65 & 1,64 \\
\hline 23 & 40 & 84 & 1,75 \\
\hline 24 & 33 & 125 & 1,95 \\
\hline 25 & 49 & 85 & 1,75 \\
\hline 26 & 61 & 76 & 1,66 \\
\hline 27 & 60 & 63 & 1,73 \\
\hline 28 & 39 & 71 & 1,78 \\
\hline 29 & 29 & 78 & 1,77 \\
\hline 30 & 41 & 72 & 1,68 \\
\hline 31 & 38 & 81 & 1,68 \\
\hline 32 & - & - & - \\
\hline 33 & 51 & 89 & 1,8 \\
\hline 34 & 31 & 74 & 1,65 \\
\hline 35 & 53 & 110 & 1,8 \\
\hline 36 & 31 & 75 & 1,72 \\
\hline 37 & 65 & 65 & 1,58 \\
\hline 38 & 31 & 110 & 1,74 \\
\hline 39 & 36 & 67 & 1,69 \\
\hline 40 & 53 & 80 & 1,73 \\
\hline 41 & 40 & 89 & 1,86 \\
\hline 42 & 39 & 92 & 1,75 \\
\hline 43 & 41 & 89 & 1,88 \\
\hline 44 & 25 & 131 & 1,8 \\
\hline 45 & 46 & 83 & 1,67 \\
\hline 46 & 41 & 136 & 1,86 \\
\hline 47 & - & - & - \\
\hline 48 & - & - & - \\
\hline 49 & 35 & 93 & 1,88 \\
\hline 50 & 19 & 88 & 1,85 \\
\hline 51 & 24 & 83 & 1,79 \\
\hline 52 & 51 & 91 & 1,67 \\
\hline Média & 42 & 88 & 1,77 \\
\hline
\end{tabular}


Tabela 4 - Dados obtidos quando da doação de plaquetas x rendimento celular obtido após isolamento de CMS.

\begin{tabular}{|c|c|c|c|c|c|c|c|c|c|c|}
\hline \multirow[b]{2}{*}{ Doador } & \multirow[b]{2}{*}{$\begin{array}{c}\text { № total } \\
\text { de } \\
\text { doações }\end{array}$} & \multirow[b]{2}{*}{ Produto } & \multirow[b]{2}{*}{$\begin{array}{l}\text { Duraçã } \\
\text { o (min) }\end{array}$} & \multirow[b]{2}{*}{$\begin{array}{l}\text { Volemia } \\
(\mathrm{mL})\end{array}$} & \multirow[b]{2}{*}{$\begin{array}{c}\text { Volemia } \\
\text { processado } \\
(\mathrm{mL})\end{array}$} & \multirow[b]{2}{*}{$\begin{array}{c}\text { Volume } \\
\text { Plq } \\
(\mathrm{mL}) \\
\end{array}$} & \multicolumn{2}{|c|}{$\begin{array}{c}\text { Volume da } \\
\text { amostra }(\mathrm{mL})\end{array}$} & \multicolumn{2}{|c|}{$\begin{array}{l}\text { Rendimento } \\
\text { celular }\left(\times 10^{6}\right)\end{array}$} \\
\hline & & & & & & & Sangue & CLR & Sangue & CLR \\
\hline 1 & 1 & $\begin{array}{c}\text { Plq } \\
\text { Simples }\end{array}$ & 47 & 5806 & 2531 & 246 & 6,6 & 7,7 & 6,53 & 407,71 \\
\hline 2 & 20 & $\begin{array}{c}\text { Plq } \\
\text { Simples }\end{array}$ & 49 & 6908 & 2323 & 243 & 7,5 & 8 & 7,4 & 613,30 \\
\hline 3 & 33 & $\begin{array}{c}\text { Plq } \\
\text { Simples }\end{array}$ & 69 & 5498 & 3137 & 242 & 7,7 & 8,5 & 5,25 & 465,38 \\
\hline 4 & 5 & $\begin{array}{c}\text { Plq } \\
\text { Simples }\end{array}$ & 64 & 5299 & 3098 & 245 & 7,7 & 10,2 & 8,95 & 78,03 \\
\hline 5 & 42 & $\begin{array}{c}\text { Plq } \\
\text { Simples }\end{array}$ & 62 & 5846 & 2757 & 242 & 7,4 & 8 & 8,3 & 1059,60 \\
\hline 6 & 25 & $\begin{array}{c}\text { Plq } \\
\text { Simples }\end{array}$ & 68 & 4766 & 3113 & 244 & 7,4 & 8,8 & 7,25 & 99,66 \\
\hline 7 & 2 & $\begin{array}{c}\text { Plq } \\
\text { Simples }\end{array}$ & 65 & 5598 & 2925 & 242 & 7,9 & 8,8 & 7,86 & 869,88 \\
\hline 8 & 43 & $\begin{array}{c}\text { Plq } \\
\text { Simples }\end{array}$ & 62 & 5738 & 2721 & 245 & 8 & 8 & 10,65 & 811,20 \\
\hline 9 & 1 & $\begin{array}{c}\text { Plq } \\
\text { Simples }\end{array}$ & 64 & 5273 & 2957 & 242 & 7 & 9,4 & 23,4 & 1548,18 \\
\hline 10 & 12 & Plq PF & 54 & 5653 & 2543 & 245 & 6 & 10 & 3,95 & 188 \\
\hline 11 & 11 & $\mathrm{Plq} \mathrm{CH}$ & 67 & 5026 & 3000 & 241 & 7 & 2,5 & 6,55 & 4,312 \\
\hline 12 & 23 & Plq Dupla & 81 & 7446 & 4653 & 448 & 7,5 & 7,5 & 18,5 & 1099,12 \\
\hline 13 & 3 & $\begin{array}{c}\text { Plq } \\
\text { Simples }\end{array}$ & 50 & 5363 & 2744 & 245 & 6,5 & 8,5 & 8,5 & 1308,15 \\
\hline 18 & 5 & $\begin{array}{c}\text { Plq } \\
\text { Simples }\end{array}$ & 63 & 5308 & 3093 & 248 & 7,7 & 9 & 11,6 & 4968 \\
\hline 21 & 3 & $\begin{array}{c}\text { Plq } \\
\text { Simples }\end{array}$ & 51 & 6068 & 2979 & 247 & 7,5 & 8 & 20 & 3120 \\
\hline 24 & 6 & Plq Dupla & 65 & 7348 & 3780 & 450 & 8 & 8,5 & 15 & 1734 \\
\hline 27 & 12 & Plq Dupla & 79 & 4532 & 3329 & 402 & 8 & 11 & 12,6 & 2244 \\
\hline 30 & 1 & $\begin{array}{c}\text { Plq } \\
\text { Simples }\end{array}$ & 48 & 4661 & 2251 & 249 & 9,5 & 12,4 & 12,4 & 1026 \\
\hline 33 & 1 & $\begin{array}{c}\text { Plq } \\
\text { Simples }\end{array}$ & 58 & 5609 & 2610 & 293 & 9 & 9,2 & 11,8 & 1048 \\
\hline 38 & 11 & Plq Dupla & 60 & 6078 & 3307 & 448 & 8 & 6 & 13,6 & 122,4 \\
\hline 39 & 2 & $\begin{array}{c}\text { Plq } \\
\text { Simples }\end{array}$ & 55 & 4628 & 2459 & 253 & 9 & 2 & 22 & 1728 \\
\hline 40 & 6 & $\begin{array}{c}\text { Plq } \\
\text { Simples }\end{array}$ & 53 & 5979 & 2521 & 250 & 7 & 2 & 9,6 & 714 \\
\hline 41 & 5 & Plq Dupla & 81 & 5830 & 4545 & 450 & 7 & 2 & 40 & 2133 \\
\hline 43 & 3 & $\begin{array}{c}\text { Plq } \\
\text { Simples }\end{array}$ & 59 & 5907 & 2878 & 250 & 7,5 & 9,5 & 9,2 & 855 \\
\hline 49 & 2 & $\begin{array}{c}\text { Plq } \\
\text { Simples }\end{array}$ & 53 & 6036 & 2341 & 250 & 6,5 & 10 & 12,2 & 1380 \\
\hline 51 & 9 & Plq Dupla & 49 & 5380 & 2896 & 448 & 8 & 10 & 12,2 & 3600 \\
\hline 52 & 5 & Plq Dupla & 49 & 5242 & 3757 & 448 & 7 & 9,5 & 11,6 & 5130 \\
\hline Média & 5 & & 60 & 5609 & 2925 & 248 & 8 & 9 & 12 & 1048 \\
\hline
\end{tabular}

CMS: células mononucleares do sangue; Plq: plaquetas; Plq simples: uma bolsa de plaqueta; Plq duplas; duas bolsas de plaquetas; Plq PF: uma bolsa de plaqueta e uma bolsa de plasma; Plq CH; uma bolsa de plaqueta e um concentrado de hemácias. 


\subsection{Recuperação das células das Câmaras de Leucorredução (CLR)}

A comparação entre as células mononucleares obtidas das CLR e do sangue foi realizada em 13 amostras de doadores (Figura 12). A mediana das amostras de sangue foi de $1 \times 10^{6}$ células/mL [IIQ: 0,$93 ; 1,32 \times 10^{6}$ ], sendo o rendimento máximo de $3,34 \times 10^{6}$ células $/ \mathrm{mL}$ e o mínimo de $0,65 \times 10^{6}$ células $/ \mathrm{mL}$. Por outro lado, amostras provenientes da CLR apresentaram rendimento aproximadamente 77 vezes maior (cel/mL) que o observado nas amostras de sangue, sendo a mediana de $76,5 \times 10^{6} \mathrm{cel} / \mathrm{mL}$ [IIQ: 15,$06 ; 139,5 \times 10^{6}$ ]. O rendimento celular mínimo obtido foi de $1,72 \times 10^{6} \mathrm{cel} / \mathrm{mL}$ enquanto que o rendimento máximo foi de $164,7 \times 10^{6} \mathrm{cel} / \mathrm{mL}$ (APÊNDICE C). Ressalta-se que não há relação entre o rendimento celular obtidas do sangue e da CLR.

Figura 12 - Comparação do rendimento celular/mL entre amostras de Sangue e CLR.



Comparação do rendimento celular/mL entre amostras de Sangue e CLR de mesmo doador. CLR: Câmara de Leucorredução. $\mathrm{n}=13 .{ }^{*} p<0,05$ para teste de Wilcoxon.

Visto que o rendimento das células mononucleares foi superior na CLR, foi analisado também o rendimento celular das subpopulações deste grupo celular. Para o cálculo do número total de cada subpopulação, utilizou-se o valor da contagem proveniente da câmara de Neubauer e a frequência de cada população analisada dentro da seleção dos eventos com tamanho e granulosidade equivalente ao de linfócitos e monócitos. 
Assim, foi analisado o rendimento das principais populações de linfócitos $T$ totais, linfócitos $\mathrm{T} \mathrm{CD}^{+}$, linfócitos $\mathrm{T} C D 8^{+}$, linfócitos $\mathrm{B}$, células $\mathrm{NK}$, monócitos e células $\mathrm{CD} 3^{+} \mathrm{CD} 56^{+}$ (Tabela 5).

Tabela 5 - Número total de populações leucocitárias recuperadas de amostras de sangue e da CLR.

\begin{tabular}{|c|c|c|c|c|c|c|c|}
\hline \multirow{3}{*}{ População } & \multirow{3}{*}{ Fenótipo } & \multicolumn{4}{|c|}{ Número de células $\left(\times 10^{6}\right)(\mathrm{cel} / \mathrm{mL})$} & \multirow{2}{*}{\multicolumn{2}{|c|}{$\frac{\text { Rendimento total }\left(\times 10^{6}\right)}{\text { CLR }}$}} \\
\hline & & \multicolumn{2}{|c|}{ Sangue } & \multicolumn{2}{|r|}{ CLR } & & \\
\hline & & Mediana & [IIQ] & Mediana & IIQ & Mediana & IIQ \\
\hline Linfócitos totais & & 0,91 & {$[0,815 ; 1,115]$} & 57,1 & {$[13,35 ; 117,8]$} & 582,6 & {$[279,2 ; 912,4]$} \\
\hline Linfócitos T & $\mathrm{CD}_{4} 5^{+} \mathrm{CD}^{+}$ & 0,59 & {$[0,56 ; 0,69]$} & 45,2 & {$[7,77 ; 77,03]$} & 422,9 & {$[165,8 ; 595,6]$} \\
\hline Linfócitos T CD4 & $\mathrm{CD}_{4} 5^{+} \mathrm{CD}^{+} \mathrm{CD}^{+} \mathrm{CD}^{-}$ & 0,39 & {$[0,35 ; 0,50]$} & 32 & {$[4,72 ; 48,19]$} & 260,3 & {$[96,05 ; 372,6]$} \\
\hline Linfócitos T CD8 & $\mathrm{CD} 45^{+} \mathrm{CD}^{+} \mathrm{CD} 4^{-} \mathrm{CD} 8^{+}$ & 0,15 & {$[0,12 ; 0,21]$} & 10,3 & {$[2,05 ; 22,27]$} & 103,4 & {$[53,15 ; 172,1]$} \\
\hline Linfócitos B & $\mathrm{CD}_{4} 5^{+} \mathrm{CD} 3^{-} \mathrm{CD} 19^{+}$ & 0,13 & {$[0,09 ; 0,21]$} & 8,1 & {$[0,94 ; 12,82]$} & 71,3 & {$[27,6 ; 117,8]$} \\
\hline Células NK (totais) & $\mathrm{CD}_{4} 5^{+} \mathrm{CD} 3^{-} \mathrm{CD} 56^{+}$ & 0,08 & {$[0,05 ; 0,11]$} & 3,8 & {$[1,4 ; 9,39]$} & 37,3 & {$[17,95 ; 81,05]$} \\
\hline Monócitos & $\mathrm{CD}_{4} 5^{+} \mathrm{CD} 3^{-} \mathrm{CD} 14^{+}$ & 0,13 & {$[0,07 ; 0,30]$} & 13,2 & {$[1,09 ; 18,58]$} & 105,9 & {$[20,5 ; 167,5]$} \\
\hline Células CD3+CD56+ & $\mathrm{CD}_{4} 5^{+} \mathrm{CD}^{+} \mathrm{CD}^{+} 6^{+}$ & 0,03 & {$[0,03 ; 0,08]$} & 1,8 & {$[0,44 ; 5,58]$} & 21,7 & {$[5,65 ; 48,35]$} \\
\hline
\end{tabular}

CLR: Câmara de Leucorredução; célula NK: célula Natural Killer; IIQ: intervalo interquartil; n=13.

Devido à maior concentração de células encontrada nas amostras da CLR verificamos que para cada subpopulação estudada, o rendimento estimado também é maior na CLR quando comparado com mesmo volume de sangue $(\mathrm{cel} / \mathrm{mL})$. Considerando o volume total da CLR é possível calcular por volta de $582,6 \times 10^{6}$ [IIQ: 279,2; 912,4] de linfócitos; 105,9×10 [IIQ: 20,5; 167,5] de monócitos e 37,3×106 [IIQ: 17,95; 81,05] de células NK (Tabela 5).

\subsection{Análise comparativa da frequência de leucócitos em amostras de sangue e da CLR}

Visto que todas as populações analisadas apresentam-se em número superior na CLR, foram analisadas as frequências dessas populações em ambas as amostras.

Para análise e cálculo de frequência das populações desejadas, foram tomados como base os eventos dentro da seleção de linfócitos de monócitos (Figura 3C).

\subsubsection{Análise da frequência de linfócitos totais em amostras de sangue e da Câmara de Leucorredução}

A análise da frequência dos linfócitos totais mostrou que esta se encontra de forma semelhante em ambas as amostras analisadas, sendo mediana de 87\% [IIQ: 84,6; 92,15] para as amostras de sangue e de $86,3 \%$ [IIQ: 83,$2 ; 89,15$ ] para amostras provenientes da CLR (Figura 13A). Ao relacionar a frequências dos linfócitos das amostras de sangue e da CLR de 
mesmo indivíduo, observa-se que há casos em que a frequência tenda a aumentar ou diminuir; mas, de maneira geral, a frequência se mantem para a CLR (Figura 13B).

Figura 13 - Análise individual da frequência e relação da população de linfócitos presentes em amostras de sangue o CLR.

A

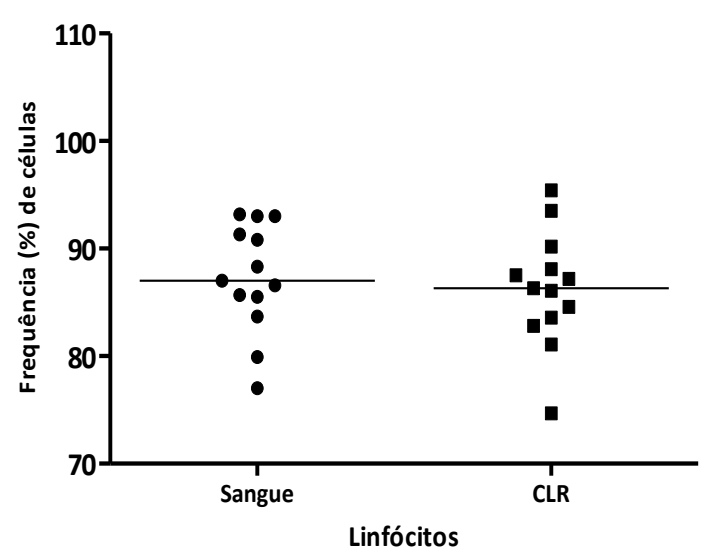

B



(A) Frequência de linfócitos no sangue (87\%; IIQ: 84,6; 92,15) e na CLR (86,1\%; IIQ: 83,2; 89,15). IIQ: intervalo interquartil. $\mathrm{n}=13$; CLR: Câmara de Leucorredução; $p>0,05$ para teste de Wilcoxon.

(B) Relação da frequência de linfócitos em amostras de sangue e CLR para o mesmo doador. n=13; CLR: Câmara de Leucorredução.

\subsubsection{Análise da frequência de linfócitos $T$ em amostras de sangue e da Câmara de Leucorredução}

Ao se comparar as frequências dos linfócitos $\mathrm{T} \mathrm{CD}^{+}$, foi possível observar que a mediana das amostras proveniente do sangue e da CLR são semelhantes: 59,5\% [IIQ: 52,4; 63,55] nas amostras de sangue e 58,3\% [IIQ: 55,15; 61,8] nas CLR (Figura 14).

$\mathrm{Na}$ análise da frequência entre as amostras observamos que esta tende a se manter semelhante entre o sangue a CLR, e, apesar de se observar um indivíduo cuja frequência está superior em relação aos outros indivíduos do grupo, observa-se esse mesmo comportamento (Figura 14B). 
Figura 14 - Análise individual da frequência e relação da população de linfócitos T presentes em amostras de sangue o CLR.

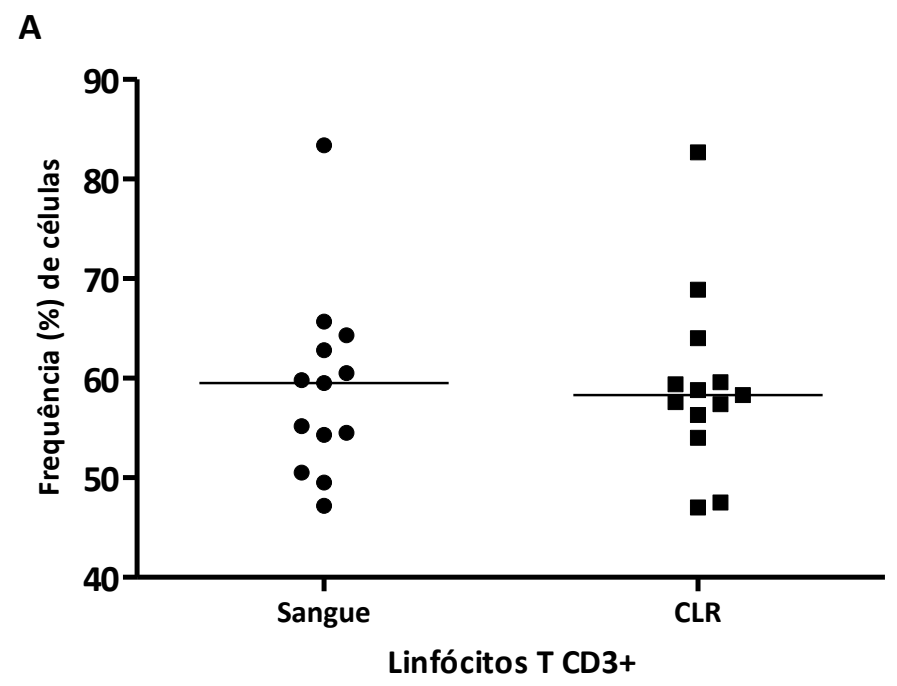

B

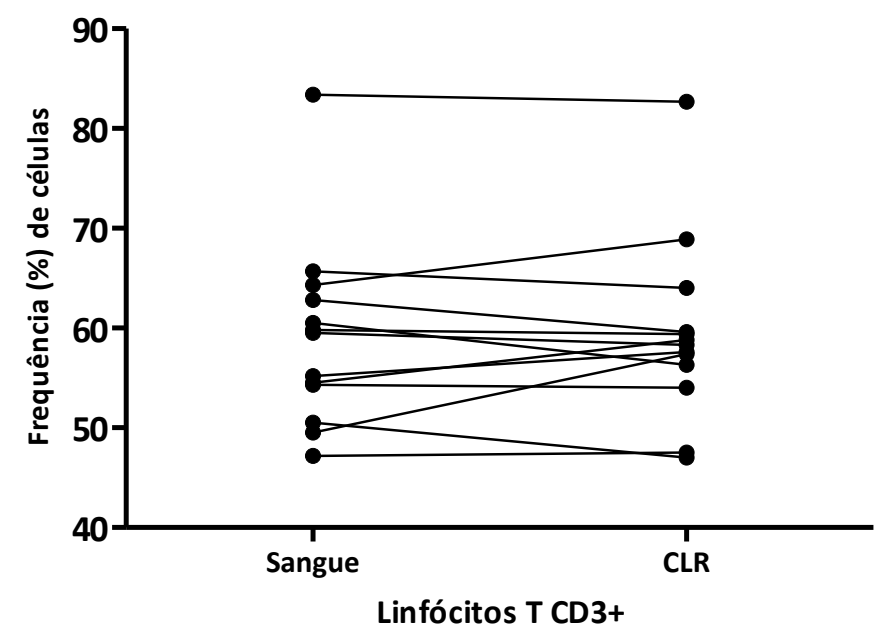

(A) Frequência de linfócitos $\mathrm{T} \mathrm{CD}^{+}$no sangue (59,5\%; IIQ: 52,4; 63,55) e na $\operatorname{CLR}(58,3 \%$; IIQ: 55,15; 61,8). Mediana; $n=13$; CLR: Câmara de Leucorredução; $p>0,05$ para teste de Wilcoxon.

(B) Relação da frequência de linfócitos $\mathrm{T} \mathrm{CD3}^{+}$em amostras de sangue e CLR para o mesmo doador. $n=13 ; \mathrm{CLR}$ : Câmara de Leucorredução.

A frequência das subpopulações T CD4 (CD4 $\left.{ }^{+} \mathrm{CD} 8^{-}\right)$e T CD8 (CD4-CD8 $\left.{ }^{+}\right)$foi calculada com base no número de eventos dentro da seleção de linfócitos e monócitos, e dentre os linfócitos $\mathrm{T} \mathrm{CD3}^{+}$(Figura 15). A distribuição dessas populações dentre o grupo de linfócitos e monócitos se dá de forma semelhante entre amostras de sangue e da CLR (Figura 15A). Ao se analisar a frequência dessas populações dentre os linfócitos $\mathrm{TCD}^{+}$, também se observa o mesmo padrão (Figura 15B). 
A mediana de Linfócitos $T C D 4^{+}$presentes no sangue e na CLR são semelhantes, sendo de 37\% [IIQ: 34,05; 39,6] para o primeiro e 36,6\% [IIQ: 33,95; 39,75] para o segundo. Os linfócitos T CD8 ${ }^{+}$apresentam frequência de 15,6\% [IIQ: 13,65; 17,6] no sangue e 15,2\% [IIQ: 13,1; 19,7] na CLR, quando essas populações são analisadas dentro dos linfócitos e monócitos (Figura 15A).

Para essas mesmas subpopulações, porém observando a frequência dentro dos linfócitos $\mathrm{T} \mathrm{CD3}^{+}$, a porcentagem de células $\mathrm{T} C \mathrm{CD} 4^{+}$no sangue e na CLR é de $65,1 \%$ [IIQ: 59,65; 68,3] e 62,9\% [IIQ: 58; 68,65], respectivamente. A frequência de T CD8 ${ }^{+}$é de $26,8 \%$ [IIQ: 23,$7 ; 29,95]$ no sangue e de $27,6 \%$ [IIQ: 23,$35 ; 31,3]$ na CLR (Figura 15B).

Figura 15 - Comparação da frequência de $\mathrm{T} \mathrm{CD}^{+}$e $\mathrm{TCD}^{+}$entre amostras de sangue e da CLR.

A

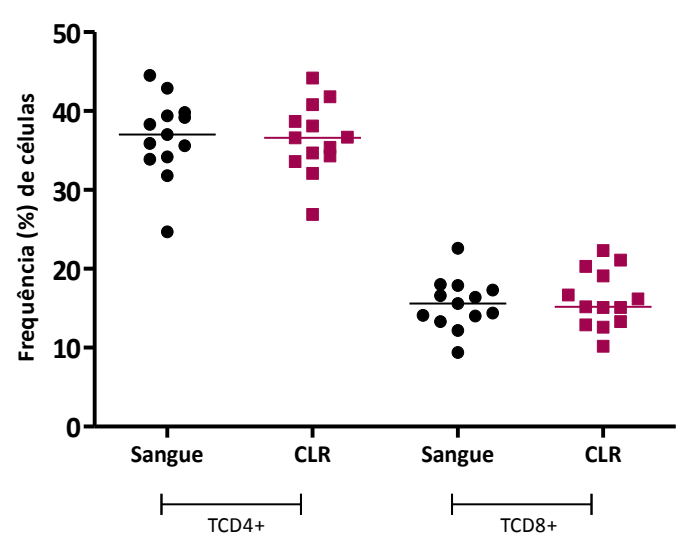

B

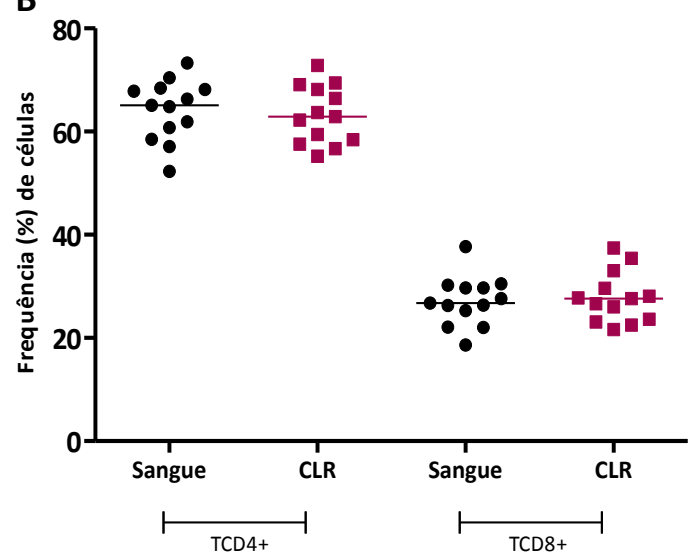

(A) Frequência de linfócitos T $\mathrm{CD}^{+}\left(\mathrm{CD}^{+}{ }^{+} \mathrm{CD} 8\right)$ no sangue (37\%; ॥Q: 34,05; 39,6) e na CLR $(36,6 \%$; II: 33,95; $39,75)$ e frequência de linfócitos T CD8 ${ }^{+}\left(\mathrm{CD}^{-} \mathrm{CD}^{+}\right)$no sangue $(15,6 \%$, IIQ: 13,$65 ; 17,6)$ e na $\operatorname{CLR}(15,2 \%, \mathrm{II}$ : $13,1 ; 19,7)$ dentro da seleção dos linfócitos e monócitos; IIQ: intervalo interquartil; $n=13$; CLR: Câmara de Leucorredução. $p>0,05$ para teste de Wilcoxon.

(B) Frequência de linfócitos T CD4 ${ }^{+}$no sangue $(65,1 \%$; IIQ: 59,65; 68,3) e na CLR $(62,9 \%$; II: 58; 68,65) e frequência de linfócitos T CD8 ${ }^{+}$no sangue $(26,8 \%$; ॥Q: 23,$7 ; 29,95)$ e na CLR $(27,6 \%$; IQ: ॥Q: 23,35; 31,3) dentre os linfócitos T CD3 ${ }^{+}$; IIQ: intervalo interquartil; $\mathrm{n}=13$; CLR: Câmara de Leucorredução. $p>0,05$ para teste de Wilcoxon.

\subsubsection{Análise da frequência de linfócitos $B$ em amostras de sangue e Câmara de Leucorredução}

Como observado para os linfócitos $T$, a frequência de linfócitos $B$ foi semelhante entre amostras de sangue e CLR, sendo de 12\% [IIQ: 8,5; 15,7] e 9,4\% [IIQ: 7,9; 13,5] respectivamente (Figura 16A). Por sua vez, a análise da relação sangue x CLR de cada doador 
mostrou que para todos os doadores a frequência de linfócitos B diminuiu em amostras da CLR (Figura 16B).

Figura 16 - Análise individual da frequência de linfócitos B presentes em amostras de sangue o CLR.



B

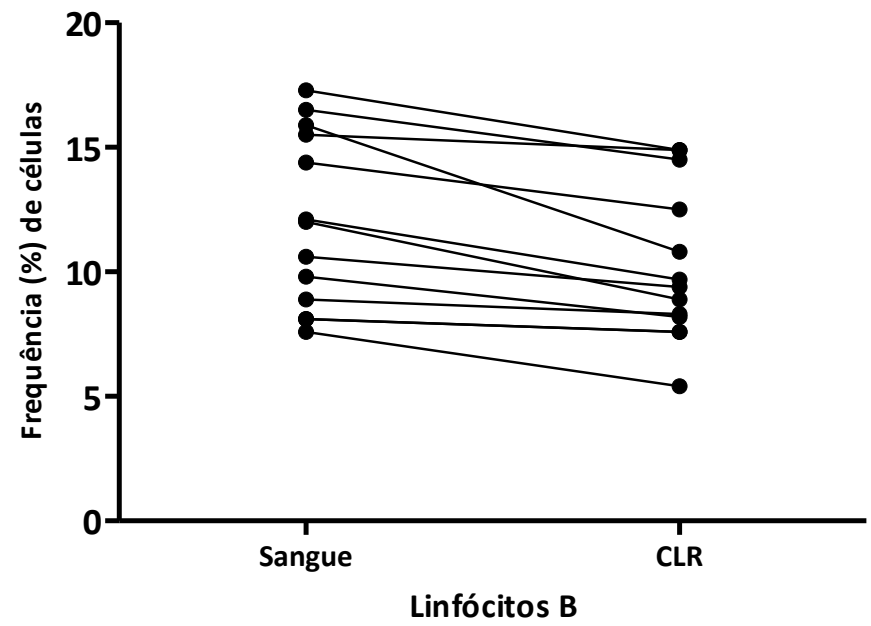

(A) Frequência de linfócitos B no sangue (12\%; IIQ: 8,5; 15,7) e na CLR (9,4\%; IIQ: IIQ: 7,9; 13,5). IIQ: intervalo interquartil; $n=13$; CLR: Câmara de Leucorredução. ${ }^{*} p<0,05$ para teste de Wilcoxon.

(B) Relação da frequência de linfócitos B no sangue e na CLR de mesmo doador. n=13; CLR: Câmara de Leucorredução.

\subsubsection{Análise da frequência de monócitos em amostras de sangue e CLR}

Da mesma forma que o observado nas outras populações, a frequência de monócitos foi semelhante nas amostras de sangue (11,3\%; IIQ: 8,65; 14,15) e da CLR (11,6\%; IIQ: 7,15; 16,6) (Figura 17A). Ao se analisar a relação da frequência estudada entre as amostras, 
observa-se uma distribuição um pouco mais heterogênea daquela observada nos linfócitos. Para alguns indivíduos, a frequência tende a aumentar na $C L R$, enquanto que para outros a frequência diminui, mas ainda assim há indivíduos em que a frequência permanece semelhante na CLR quando comparada com o sangue (Figura 17B).

Figura 17 - Análise individual da frequência de monócitos (CD3 $\left.{ }^{-} \mathrm{CD} 14^{+}\right)$presentes em amostras de sangue e da CLR.

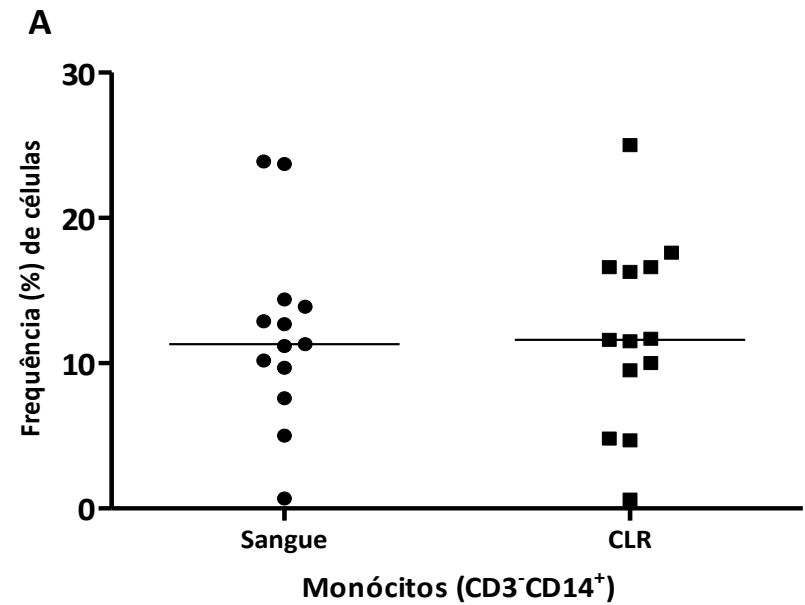

B

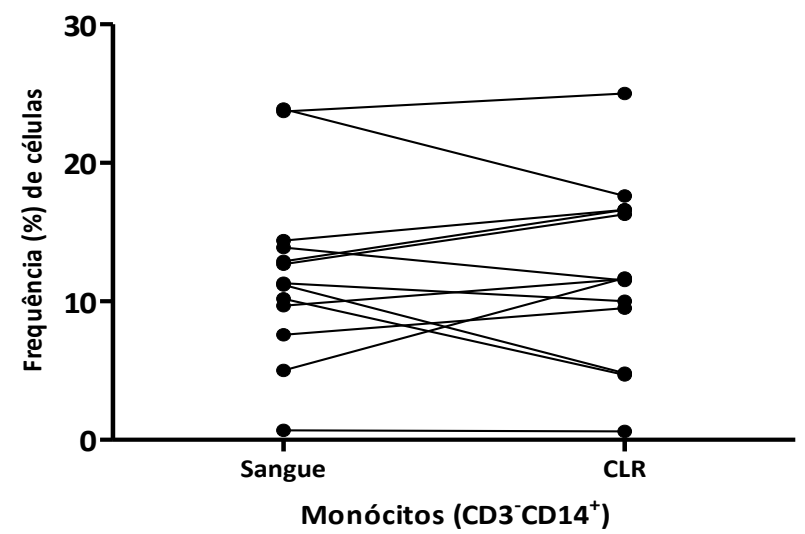

(A) Frequência de monócitos no sangue (11,3\%; IIQ: 8,65; 14,15) e na CLR (11,6\%; \%; IIQ: 7,15; 16,6). IIQ: intervalo interquartil; $n=13$; CLR: Câmara de Leucorredução. $p>0,05$ para teste de Wilcoxon

(B) Relação da frequência de monócitos em amostras de sangue e CLR para o mesmo doador. $n=13 ; C L R$ : Câmara de Leucorredução.

\subsubsection{Análise da frequência de células $\mathrm{NK}$ e células $C D 3^{+} \mathrm{CD} 56^{+}$em amostras de sangue $e$ Câmara de Leucorredução}

A análise das células $\mathrm{NK}\left(\mathrm{CD} 3^{-} \mathrm{CD} 56^{+}\right)$mostrou a presença de uma população $\mathrm{CD}^{-}$ CD56 $6^{\text {bright }}$, assim, a frequência dessa subpopulação também foi analisada. Para a análise das células NK foram então consideradas as células NK totais (que corresponde à soma das 
células $\mathrm{CD}^{-} \mathrm{CD}^{+} 6^{+}$e $\mathrm{CD}^{-} \mathrm{CD} 56^{\text {bright }}$ ), somente as células $\mathrm{CD}^{-} \mathrm{CD} 56^{+}$(Células $\mathrm{NK}$ convencionais) e somente as células CD3-CD56 brigth (Figura 6).

A frequência das células NK totais foi de 7,5\% [IIQ: 2,6; 8,95] no sangue e 7,3\% [IIQ: 2,2; 10,1] na CLR (Figura 18A). As células CD3 $\mathrm{CD}^{-} 6^{+}$apresentam frequência de $6,9 \%$ no sangue [IIQ: 4,4; 10,15] e na CLR [IIQ: 5,25; 10,8] (Figura 18B). A frequência das células CD3 CD56 $6^{\text {bright }}$ foi de $0,4 \%$ no sangue [IIQ: 0,27; 0,65] e na CLR [IIQ: 0,23; 0,71] (Figura 18B).

Figura 18 - Análise da frequência de células NK $\left(C D 3^{-} C D 56^{+}\right)$presentes em amostras de sangue o CLR de mesmos indivíduos.

A

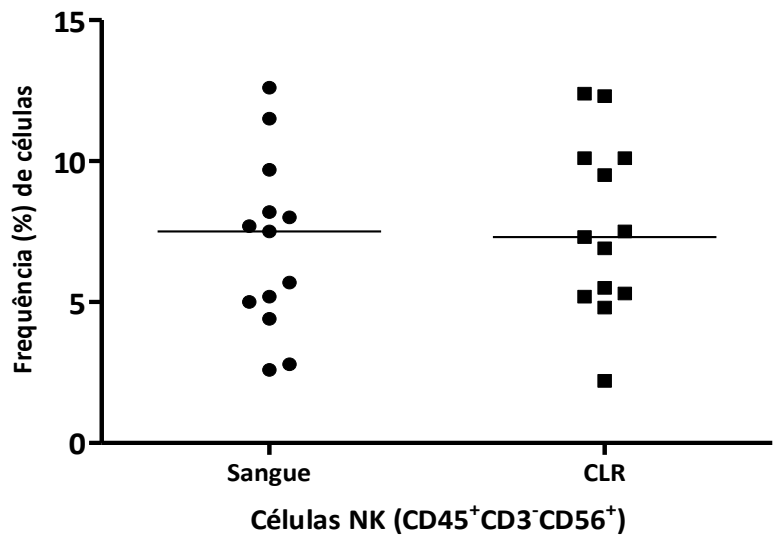

B

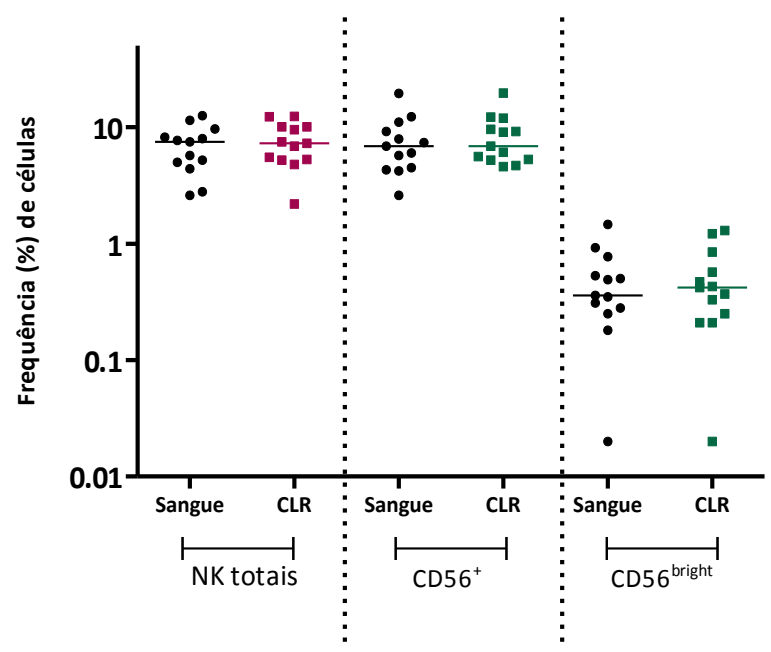

(A) Frequência de células NK totais presentes no sangue (7,5\%; IIQ: 2,6; 8,95) e na CLR (7,3\%; IIQ: 2,2; 10,1). ॥Q: intervalo interquartil; $\mathrm{n}=13$; CLR: Câmara de Leucorredução. $p>0,05$ para teste de Wilcoxon.

(B) Frequência das células NK CD3 ${ }^{-}{ }^{-1} 56^{+}$presentes no sangue $(6,9 \%$; IIQ: 4,4; 10,15) e na CLR $(6,9 \% ; \| I$ : 5,25; 10,8); e frequência das células NK CD3 ${ }^{-} D^{2} 6^{\text {bright }}$ presentes no sangue $(0,4 \%$; II: 0,$27 ; 0,65)$ e a CLR $(0,4 \%$; IIQ: $0,23 ; 0,71)$ do mesmo doador. Mediana. $n=13$; CLR: Câmara de Leucorredução. $p>0,05$ para teste de Wilcoxon.

Durante a análise dos dados, foi possível a identificação de uma população $\mathrm{CD}^{+} \mathrm{CD} 56^{+}$. Embora não se possa afirmar que sejam células NK-T, devido à ausência de outros marcadores; essa população pode ser um indicativo da presença de células NK-T na CLR. A distribuição dessa população no sangue e na CLR está demonstrada na Figura 19. A mediana da frequência de células $\mathrm{CD}^{+} \mathrm{CD} 6^{+}$também é semelhante em ambas as amostras: 4,6\% [IIQ: 2,5; 5,45] no sangue e 4,1\% [IIQ: 2,9; 6,66] na CLR (Figura 19A). A relação entre amostras de sangue e CLR mostra que os pontos nos extremos da dispersão correspondem ao mesmo indivíduo, indicando que a frequência no sangue corresponde à frequência na CLR (Figura 19B). 
Figura 19 - Análise individual da frequência de células NK $\left(\mathrm{CD}^{-} \mathrm{CD}^{-} 6^{+}\right)$presentes em amostras de sangue e da CLR.



B

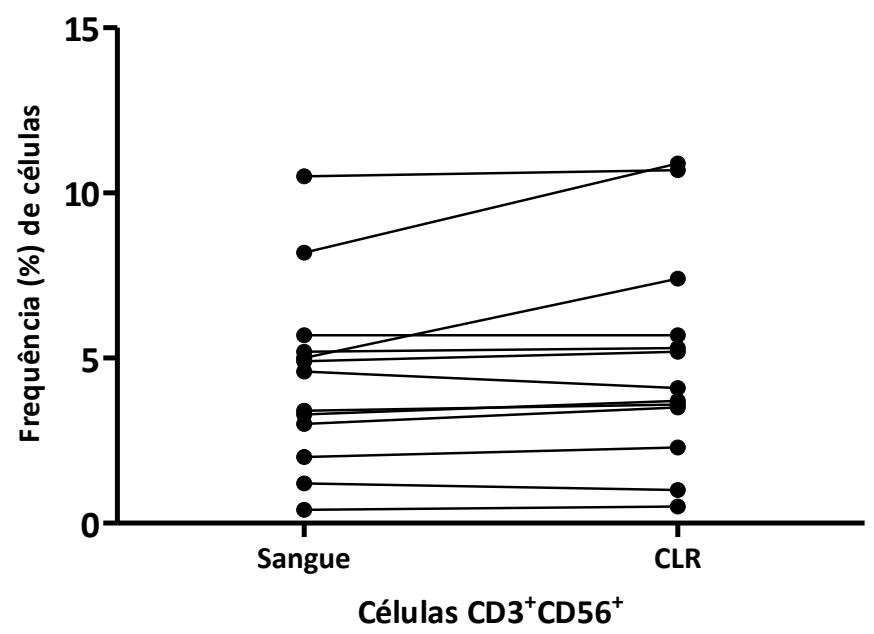

(A) Frequência de células NK no sangue $(4,6 \% ; \| Q: 2,5 ; 5,45)$ e na CLR (4,1\%; ॥Q: 2,9; 6,66). ॥Q: intervalo interquartil; $n=13$; CLR: Câmara de Leucorredução. $p>0,05$ para teste de Wilcoxon.

(B) Relação da frequência de células $\mathrm{CD}^{+}{ }^{+} \mathrm{CD} 56^{+}$no sangue e na $\mathrm{CLR}$ do mesmo doador. $n=13$; $C L R$ : Câmara de Leucorredução.

\subsection{Análise do perfil funcional de linfócitos presentes em amostras de sangue e da Câmara de Leucorredução}

Para avaliar o perfil de ativação dos linfócitos presentes na CLR, foram analisadas a expressão do marcador inicial de ativação, CD69, em linfócitos T e B, e a expressão das cadeias alfa e beta do receptor de alta afinidade de IL2 (CD25 e CD122, respectivamente). Foi estudada também a expressão de CD45RA e CD45RO em linfócitos T. 
O estudo da expressão dos marcadores de ativação em linfócitos T e B CD69, CD122, CD25 e a expressão das proteínas CD45RA e CD45RO indicou semelhança entre as células presente na amostra de sangue da CLR.

A expressão do marcador inicial de ativação CD69 foi avaliada em linfócitos T $\mathrm{CD}^{+} \mathrm{CD} 8^{-}$, linfócitos $\mathrm{T} \mathrm{CD}^{-} \mathrm{CD} 8^{+}$e linfócitos $\mathrm{B}\left(\mathrm{CD} 4^{-} \mathrm{CD} 8^{-} \mathrm{CD} 19^{+}\right)$conforme ilustrado na Figura 7. A frequência foi avaliada dentro de cada subpopulação. A expressão de CD69 em células T $\mathrm{CD}^{+}$foi de $0,4 \%$ [IIQ: 0,3; 0,6] em amostras de sangue, e de $0,2 \%$ [IIQ: 0,$\left.17 ; 0,32\right]$ nas amostras da CLR (Figura 20A). As células T CD8 ${ }^{+}$apresentaram frequência de 1,3\% [IIQ: 0,87; 1,82] no sangue e de 1,2\% [IIQ: 0,57; 1,35] na CLR de CD69 (Figura 20B). Para os linfócitos B, a expressão do marcador inicial de ativação também se deu de forma semelhante no sangue e na CLR, correspondendo a 0,06\% [IIQ: 0,03; 0,12] e 0,05\% [IIQ: 0,01;0,09] no sangue e na CLR, respectivamente (Figura 20C).

Figura 20: Análise comparativa da expressão de CD69 em linfócitos T e B em amostras de sangue e de CLR.

A

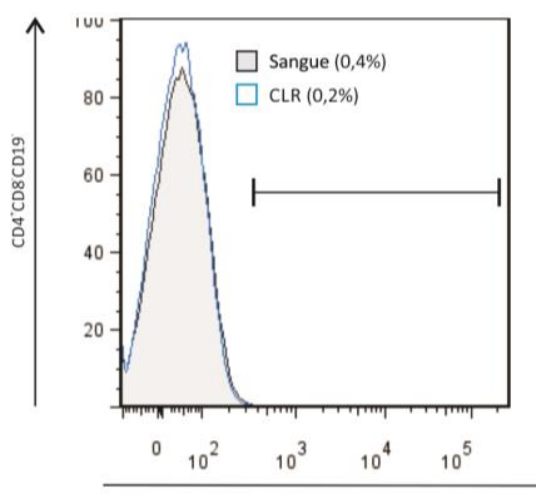

B

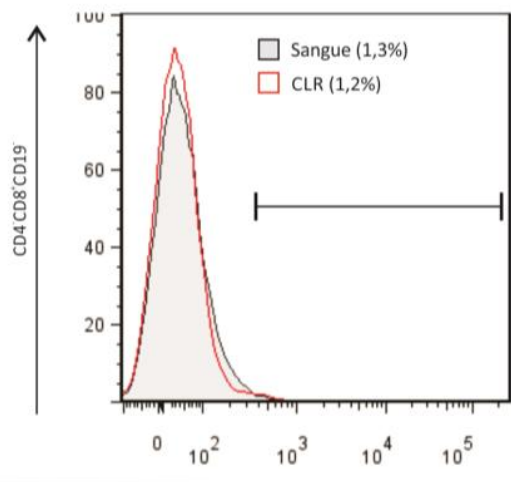

C

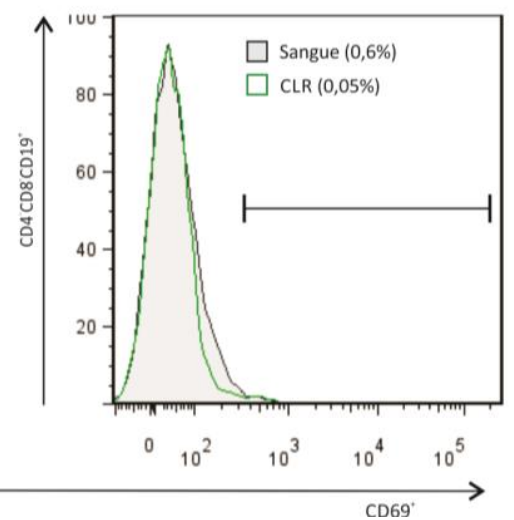

(A) Expressão de CD69 em linfócitos T CD4 ${ }^{+} \mathrm{CD} 8{ }^{-}$em amostras de sangue $(0,4 \%$; $\| Q: 0,3 ; 0,6)$ e $\operatorname{CLR}(0,2 \%$; IQ: $0,17 ; 0,32)$. IIQ: intervalo interquartil. $\mathrm{n}=13$; CLR: Câmara de Leucorredução. ${ }^{*} p<0,05$ para teste de Wilcoxon.

(B) Expressão de CD69 em linfócitos T CD4 CD8 ${ }^{+}$em amostras de sangue (1,3\%; ॥Q: 0,87; 1,82) e CLR (1,2\%; ॥Q: 0,57; 1,35). IIQ: intervalo interquartil. $n=13$; CLR: Câmara de Leucorredução. $p>0,05$ para teste de Wilcoxon.

(C) Expressão de CD69 em linfócitos $B\left(C D 4 C D 8{ }^{-} C^{-} 19^{+}\right)$em amostras de sangue $(0,06 \%$; IIQ: 0,03; 0,12) e CLR (0,05\%; IIQ: 0,01; 0,09). IIQ: intervalo interquartil. $n=13$; CLR: Câmara de Leucorredução. $p>0,05$ para teste de Wilcoxon.

A análise de relação mostra tendência na redução da expressão de CD69 nos linfócitos T CD4 (Figura 21A). Essa mesma tendência não é observada para os linfócitos T CD8 (Figura 21B) e Linfócitos B (Figura 21C). Assim, nas células provenientes da CLR a expressão desse marcador inicial de ativação é menor em linfócitos T CD4. 
Figura 21 - Análise individual da relação da expressão de CD69 em linfócitos T CD4 ${ }^{+}$; T CD8 ${ }^{+}$e Linfócitos B em amostra de sangue e da CLR.

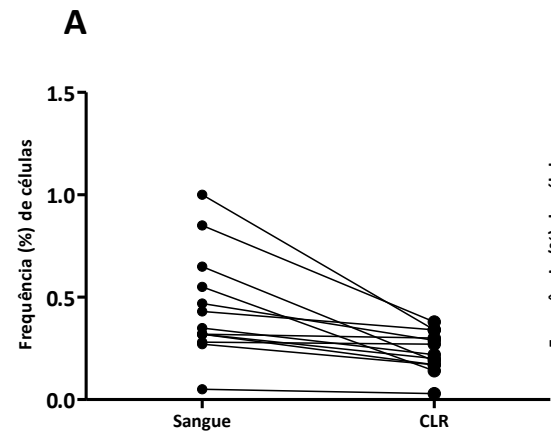

Linfócitos $\mathrm{TCD4}^{+} \mathrm{CD}^{+} 9^{+}$

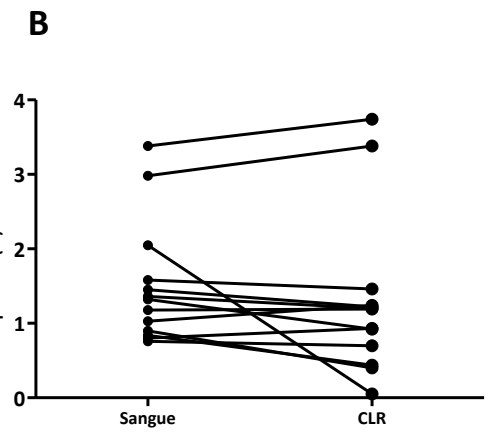

Linfócitos T $\mathrm{CD}^{+} \mathrm{CD}^{+} 9^{+}$

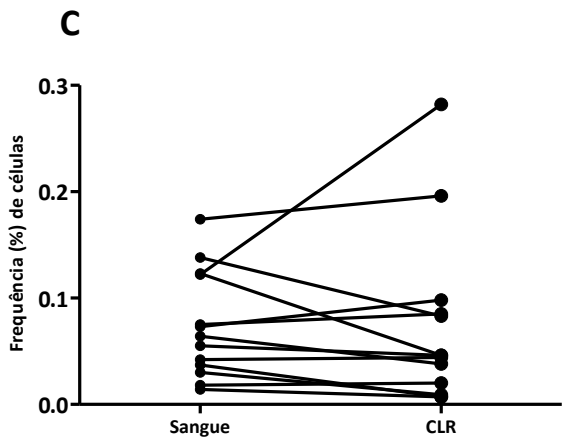

Linfócitos T CD19+CD69+

n=13; CLR: Câmara de Leucorredução.

A análise da expressão das cadeias alfa e beta do receptor de IL-2 (CD25 e CD122,

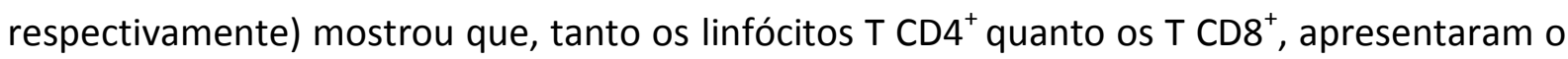
mesmo padrão de expressão das amostras de sangue e da CLR.

Os dados mostram que a maior parte das células apresenta um perfil duplo-negativo para a co-expressão de CD25 e de CD122 (CD25 CD122), indicando não ativação celular. Nos linfócitos T CD4, a frequência dessas células foi de 95\% [IIQ: 90,28; 95,97] nas amostras de sangue, e de 94,5\% [IIQ: 90,4; 95,59] nas amostras de CLR. Nos linfócitos T CD8, a frequência dessas células está ainda maior, mas ainda semelhante entre as duas amostras, sendo de 97,8\% [IIQ: 96,52; 98,92] em amostras de sangue e de 98,1\% [IIQ: 96,58; 99,15] em amostras da CLR (Figura 22).

A expressão das duas cadeias do receptor de IL-2 seria um indício de ativação celular, no entanto, a frequência de células duplo-positiva (DP) $\left(\mathrm{CD} 25^{+} \mathrm{CD} 122^{+}\right)$foi praticamente nula tanto para T CD4 como TCD8. No sangue, a frequência de células TCD4 DP foi de 0,02\% [IIQ: 0,009; 0,003], a mesma encontrada na CLR [IIQ: 0,0008; 0,05]. Entre os linfócitos T CD8, a frequência de células DP foi de 0,01\% [IIQ: 0; 0,03] no sangue e de 0,02\% na CLR [IIQ: 0,001; 0,03] (Figura 22). 
Figura 22 - Análise comparativa da expressão das cadeias alfa (CD25) e beta (CD122) do receptor de alta afinidade para IL-2 em linfócitos T $\mathrm{CD} 4^{+}$e T $\mathrm{CD} 8^{+}$.

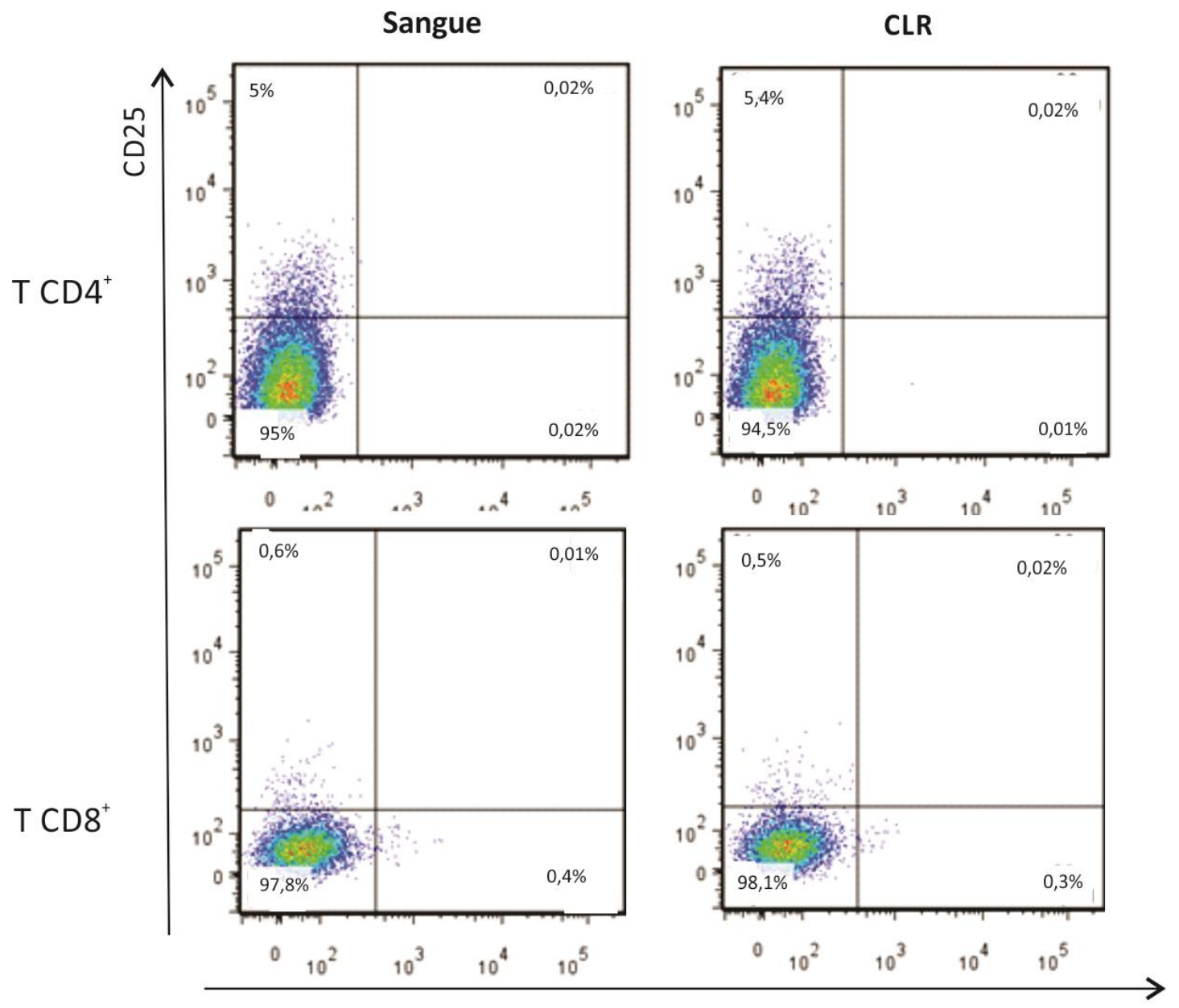

CD122

Expressão de CD25 e CD122 em linfócitos T CD4 e T CD8 em amostras de sangue e da CLR. Frequência de células TCD4 duplo-positivas foi de 0,02\% [IIQ: 0,009; 0,003] no sangue e na CLR [IIQ: 0,0008; 0,05]. Em linfócitos T CD8, a frequência de células duplo-positivas foi de 0,01\% [IIQ: 0; 0,03] no sangue e de 0,02\% na CLR [IIQ: 0,$001 ; 0,03$ ]. $n=12$; CLR: Câmara de Leucorredução. $p>0,05$ para teste de Wilcoxon.

A análise da expressão de CD45RA e CD45RO foi realizada em linfócitos $T^{2} C^{+}{ }^{+}$e linfócitos $\mathrm{T} \mathrm{CD8}^{+}$. Tanto nas amostras de sangue como nas amostras da CLR foi possível observar três populações distintas: uma população $C^{2} 45 R^{+}{ }^{+} C D 45 R 0^{-}$, outra população $\mathrm{CD} 45 \mathrm{RA}^{-} \mathrm{CD} 45 \mathrm{RO}^{+}$e uma população com expressão intermediária de ambos marcadores, (CD45RA ${ }^{\text {int }} C$ 45RO ${ }^{\text {int }}$ ) (Figura 9). A população simples positiva CD45RA $^{+}$corresponde aos linfócitos $\mathrm{T}$ naïves, ao passo que a população simples positiva $\mathrm{CD}_{4} 5 \mathrm{RO}^{+}$corresponde aos linfócitos T de memória.

Ao se comparar as comparar as frequências desses marcadores em cada subpopulação, observa-se que a mediana da frequência foi semelhante entre as amostras de sangue e da CLR. Nas células T CD4 ${ }^{+}$a mediana da frequência das células $\mathrm{CD}_{4} 5 \mathrm{RA}^{+}$foi de 
26,3\% [IIQ: 18,52; 42,89] nas amostras de sangue, e de 24,1\% [IIQ: 15,78; 35,25] nas amostras da CLR. A frequência da expressão intermediária de ambos os marcadores (CD45RA ${ }^{\text {int }}$ CD45RO $^{\text {int }}$ ) foi de 22,1\% [IIQ: 21,67; 28,09] no sangue e $21,8 \%$ [IIQ: 21,$41 ; 24,89$ ] na CLR. As células de memória representam 43\% [IIQ: 43,38; 56,28] de linfócitos T CD4 no sangue e 47\% [IIQ: 39,73; 58,11] na CLR (Figura 23A).

A expressão dessas mesmas proteínas nos linfócitos T CD8 ${ }^{+}$também foi semelhante entre as amostras. Nesta subpopulação, as células naïve (CD45RA $\left.{ }^{+} C D 45 R 0^{-}\right)$representam 54,5\% [IIQ: 42,45; 60,05] e 50,1\% [IIQ: 38,42; 55,25] do total de células T CD8 ${ }^{+}$no sangue e na CLR respectivamente. As células de memória representam 16,6\% [IIQ: 9,93; 25,17] (sangue) e 20,5\% [IIQ: 11,43; 27,3] (CLR) desse total. Já a população intermediária $\left(C D 45 R A^{\text {int }} C^{2} 45 R^{\text {int }}\right.$ ) representa 28,3\% [IIQ: 22,44; 31,77] do total de T CD8 no sangue e 31,1\% [IIQ: 25,49; 34,74] do total de T CD8 na CLR (Figura 23B).

Apensar das frequências de células naïve, intermediárias ou de memória serem muito próximas tanto para linfócitos T CD4 como para os linfócitos T CD8, é possível notar uma série de tendências quando se analisa a relação de cada perfil separadamente. As células T CD4 naïve apresentam uma leve tendência de diminuição nas amostras da CLR em relação ao sangue (Figura 24A), enquanto que a população $C D 45 R A^{\text {int }} C D 45 R 0^{\text {int }}$ parece permanecer constantes (Figura 24B) e as células de memória apresentam pequeno aumento de frequência na CLR (Figura 24C).

Dentre os linfócitos T CD8, também foi possível observar uma leve tendência de diminuição de linfócitos naïve na CLR que a diminuição observada nos linfócitos T CD4 (Figura 24D). Apesar das células com perfil fenotípico intermediário parecer constante nas amostras de sangue e CLR, em alguns indivíduos, a frequência desse subgrupo celular aumenta nas amostras provenientes da CLR (Figura 24E). Já os linfócitos de memória apresentam pequeno aumento nas células de memória nas amostras da CLR comparativamente ao sangue. 
Figura 23: Análise da expressão de CD45RA e CD45RO em populações de linfócitos $T \mathrm{CD}^{+}$e $\mathrm{T}$ CD8 ${ }^{+}$em amostras de sangue e da CLR.

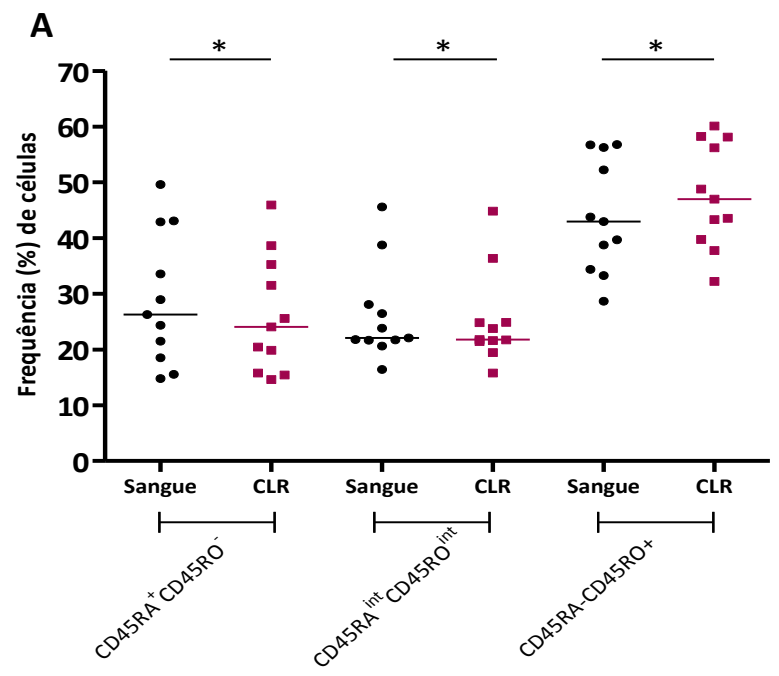

Linfócitos T CD4 ${ }^{+}$

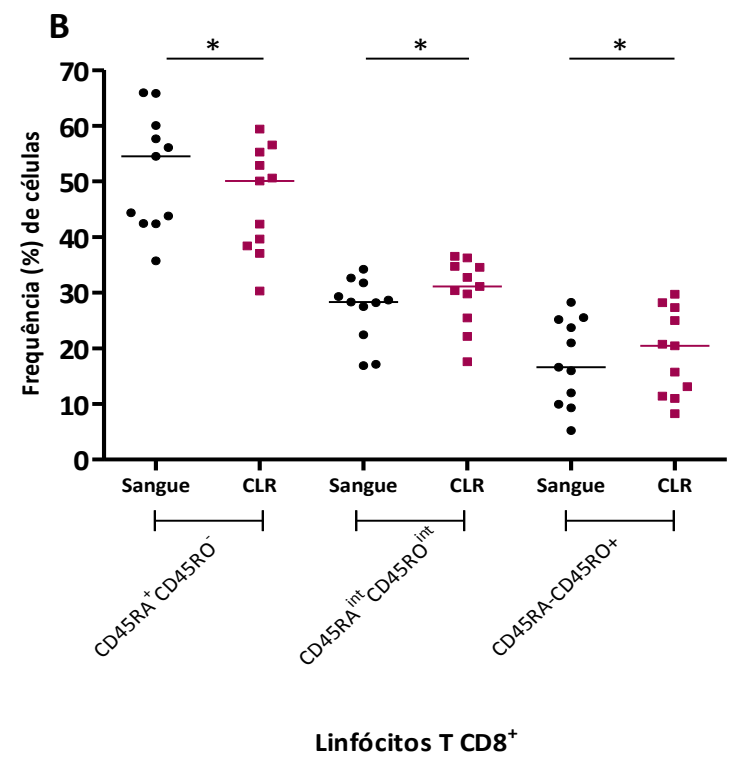

(A) Expressão de CD45RA e CD45RO em T CD4 ${ }^{+}$. Frequência das populações naïves ( $C D$ 45RA $\left.{ }^{+} C D 45 R O\right)$ em amostras de sangue (26,3\%; IIQ: 18,52; 42,89) e da CLR (24,1\%; IIQ: 15,78; 35,25) frequência de células $\operatorname{CD}_{45 R A}{ }^{\text {int }} C D 45 R O^{\text {int }}$ em amostras de sangue $(22,1 \%$; IIQ: 21,$67 ; 28,09)$ e da CLR $(21,8 \% ; \|$ : 21,$41 ; 24,89)$; frequência de células de memória (CD45RA $\left.{ }^{+} C D 45 R O\right)$ ) em amostras de sangue (43\%; IIQ: 43,38; 56,28$)$ e da CLR (47\%; IIQ: 39,73; 58,11). IIQ: intervalo interquartil; $\mathrm{n}=12$; CLR: Câmara de Leucorredução. ${ }^{*} p<0,05$ para teste de Wilcoxon.

(B) Expressão de CD45RA e CD45RO em T CD8 ${ }^{+}$. Frequência das populações naïves ( $C D$ 45RA $\left.{ }^{+} C D 45 R O\right)$ ) em amostras de sangue (54,5\%; IIQ: 42,45; 60,05) e da $\operatorname{CLR}(50,1 \%$; II: 38,42; 55,25); frequência de células CD45RA ${ }^{\text {int }} C D 45 R O^{\text {int }}$ em amostras de sangue (28,3\%; IIQ: 22,44; 31,77) e da $\operatorname{CLR}(31,1 \%$; IIQ: 25,49; 34,74); frequência de células de memória (CD45RA $\left.{ }^{+} C D 45 R O{ }^{\circ}\right)$ em amostras de sangue $(16,6 \%$; IIQ: 9,93; 25,17) e da CLR (20,5\%; IIQ: 11,43; 27,3). IIQ: intervalo interquartil; $n=12$; CLR: Câmara de Leucorredução. * $p<0,05$ para teste de Wilcoxon. 
Figura 24 - Análise individual da correlação da expressão de CD45RA e CD45RO em linfócitos T CD4 e T CD8 em amostra de sangue e CLR.

A



Linfócitos T CD4 ${ }^{+} \mathrm{CD} 4 \mathrm{RA}^{+} \mathrm{CD} 45 \mathrm{RO}$



Linfócitos T CD8 ${ }^{+}$CD45RA ${ }^{+}$CD45RO-

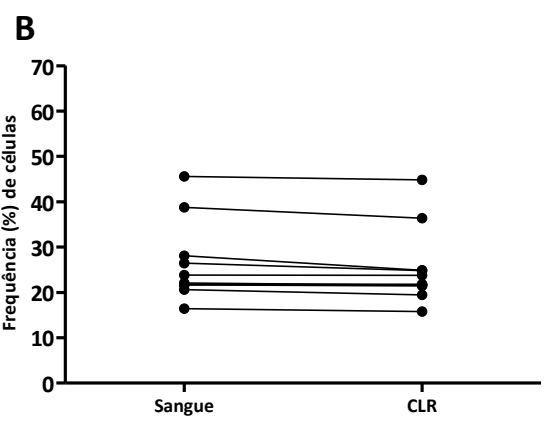

Linfócitos T CD4 ${ }^{+} \mathrm{CD} 45 \mathrm{RA}^{+} \mathrm{CD} 45 \mathrm{RO} 0^{+}$

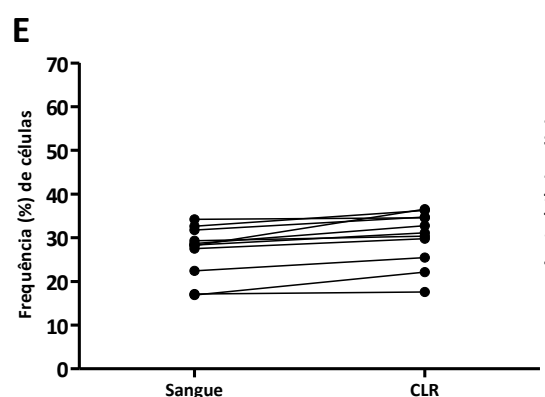

Linfócitos T CD8 ${ }^{+}$CD45RA ${ }^{+}$CD45RO

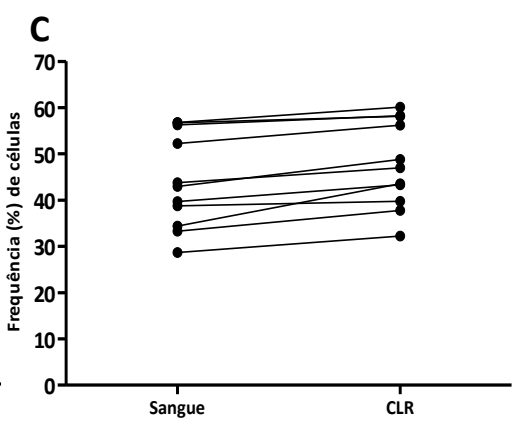

Linfócitos T CD4 ${ }^{+}$CD45RA-CD45RO+



Linfócitos T CD8 ${ }^{+} \mathrm{CD}^{-}$5RA-CD45RO

Relação de linfócitos T CD4 entre amostras de sangue e CLR para células CD45RA ${ }^{+} \mathrm{CD}^{4} 5 \mathrm{RO}^{-}$(A), CD45RA $^{\text {int }} C$ 45RO ${ }^{\text {int }}(B)$ e CD45RA ${ }^{-} O^{+}(C)$; e correlação linfócitos T CD8 entre amostras de sangue e CLR para



\subsection{Análise do perfil funcional de células provenientes da Câmara de Leucorredução em comparação com amostras de sangue}

\subsubsection{Análise do potencial proliferativo de linfócitos $T$ de amostras de sangue e da CLR}

A fim de analisar o perfil proliferativo dos linfócitos $T$ realizamos ensaios de proliferação celular mediante estímulo com Fitohemaglutinina (PHA) em duas doses previamente estabelecidas para induzir taxas de proliferação mais altas $(0,5 \mu \mathrm{l} /$ poço) e menores $(0,125 \mu \mathrm{L} /$ poço) .

A proliferação observada nos linfócitos T CD4, foi semelhante entre o sangue e a CLR nos três tratamentos (controle, PHA 0,5 $\mu \mathrm{l} /$ poço e PHA 0,125 $\mu \mathrm{l} /$ poço) (Figura 25). Nas amostras que não receberam estímulo, a proliferação observada foi de 8,7\% [IIQ: 4,52; 9,15] nas amostras de sangue, e de 7,1\% [IIQ: 3,12; 15,95] nas amostras da CLR. As amostras de sangue que receberam 0,5 $\mu \mathrm{l} /$ poço de estímulo proliferaram 75,5\% [IIQ: 67,06; 83,3], 
enquanto as amostras da CLR que receberam a mesma quantidade de estímulo proliferaram 69,3\% [IIQ: 53,03; 78,66]. As amostras que receberam menor quantidade de PHA $(0,125$ $\mu \mathrm{l} /$ poço) proliferaram em menor escala, mas ainda assim, de forma semelhante entre as amostras, sendo de $35 \%$ [IIQ: 17,$61 ; 56,55]$ para o sangue e $37,5 \%$ [IIQ: 27,$12 ; 55,32]$ para a CLR.

Quando são analisadas as relações entre as amostras, observa-se que o perfil proliferativo é heterogêneo principalmente nas amostras que não receberam nenhum tratamento (Figura 26A), e nas amostras que receberam menos estímulo (Figura 26C). Já as amostras da CLR que receberam maior quantidade de estímulo (PHA 0,5 $\mu \mathrm{l} /$ poço), apresentara um perfil de proliferação mais heterogêneo (Figura 26B).

Figura 25 - Análise proliferativa de linfócitos $\mathrm{T} \mathrm{CD4}^{+}$de amostras de sangue e de CLR, de mesmo indivíduo, frente a quantidades diferentes de PHA.

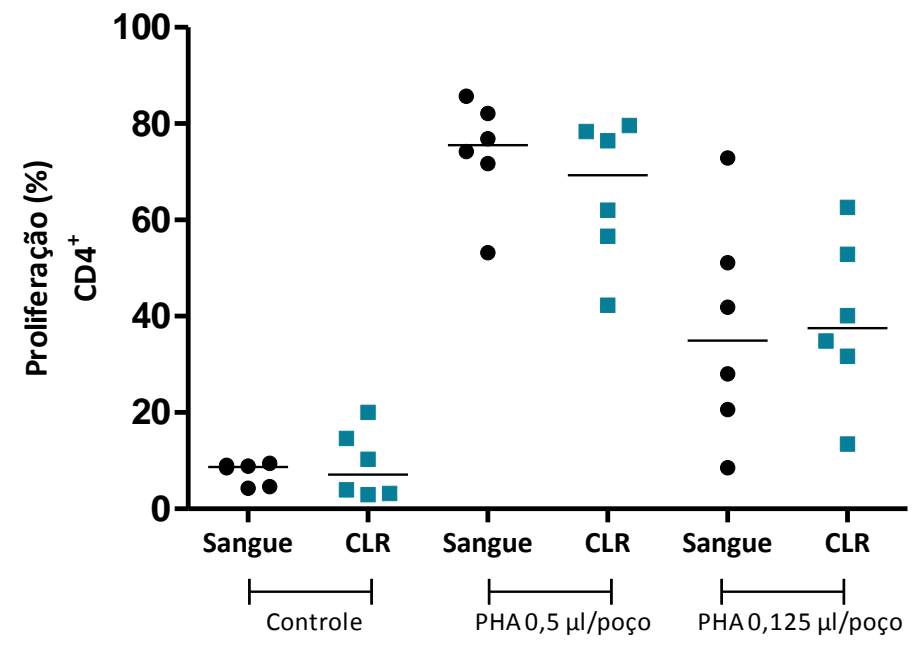

Proliferação de linfócitos T CD4 ${ }^{+}$em amostras de sangue e da CLR em diferentes tratamentos. Controle (sem estímulo): proliferação de 8,7\% [IIQ: 4,52; 9,15] em amostras de sangue e de 7,1\% [IIQ: 3,12; 15,95] em amostras da CLR. Tratamento PHA 0,5 $\mu$ l/poço: proliferação de 75,5\% [IIQ: 67,06; 83,3], nas amostras do

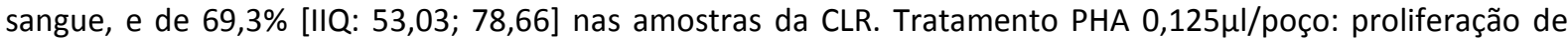
35\% [IIQ: 17,61; 56,55] para amostras do sangue e 37,5\% [IIQ: 27,12; 55,32] para amostras da CLR. IIQ: Intervalo interquartil; $\mathrm{n}=6$; CLR: Câmara de Leucorredução. $p>0,05$ para teste de Wilcoxon. 
Figura 26 - Análise individual da correlação da expressão da proliferação de linfócitos T CD4 ${ }^{+}$em amostra de sangue e da CLR.
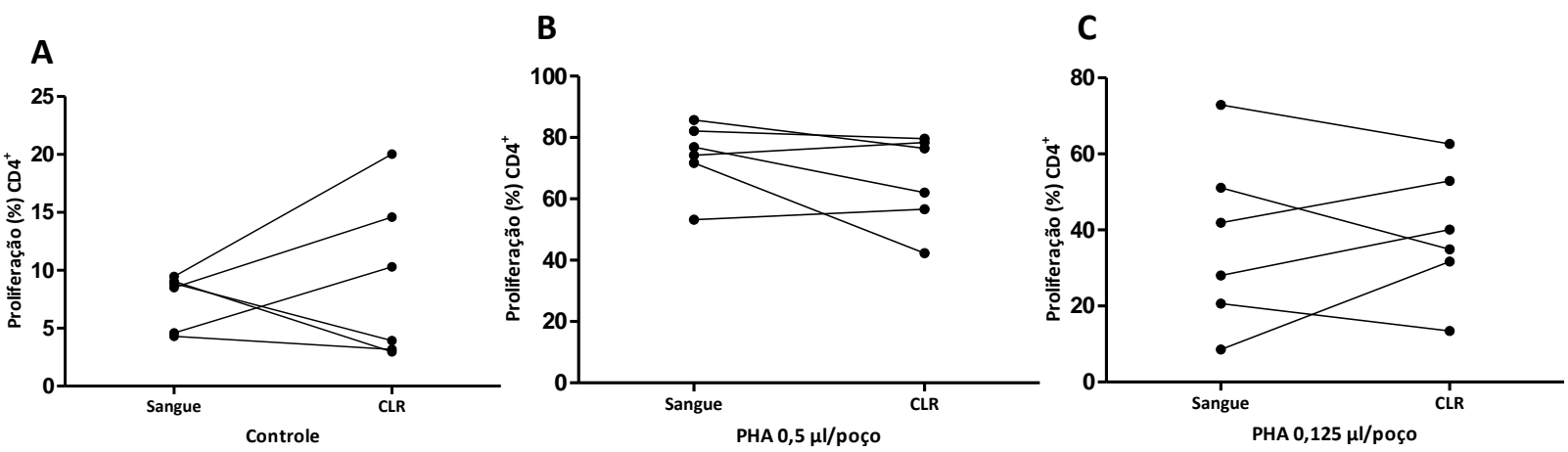

Perfil da resposta proliferativa de linfócitos $\mathrm{T} \mathrm{CD4}^{+}$frente a diferentes tratamentos: $(\mathrm{A})$ controle; (B) PHA 0,5 $\mu \mathrm{l} /$ poço; (C) PHA 0,125 $\mu \mathrm{l} /$ poço. n=6; CLR: Câmara de Leucorredução.

A análise da proliferação dos linfócitos $\mathrm{T} \mathrm{CD}^{+}$das amostras de sangue e da $\mathrm{CLR}$ também apresentou proliferação semelhante, embora nos tratamentos com estímulo de PHA, a mediana de proliferação tenha sido inferior na CLR (Figura 27). A proliferação das amostras que não receberam estímulo foi de 7,2\% [IIQ: 5,09; 10,11] e de 7,9\% [IIQ: 3,11; $15,44]$ nas amostras de sangue e da CLR, respectivamente. Nas amostras que receberam maior estímulo $(0,5 \mu \mathrm{l}$ de PHA/poço), a proliferação foi de $79,4 \%$ [IIQ: 68,58; 86,29] nas amostras provenientes do sangue, e de 73,1\% [IIQ: 59,90; 84,23] nas amostras da CLR. As amostras de sangue que receberam menor quantidade de estímulo proliferaram $57,1 \%$ [IIQ: 29,86; 66,51], enquanto que as amostras da CLR proliferaram 52,7\% [IIQ: 38,99; 68,86].

A relação das amostras nos diferentes tratamentos, assim como para os linfócitos T $\mathrm{CD}^{+}$também mostra um padrão heterogêneo para as amostras sem estímulo e para aquelas que receberam menor quantidade de PHA (Figura 28A e 28C, respectivamente), enquanto que para as amostras que receberam maior quantidade de PHA, os linfócitos T CD8 pareçam proliferar um pouco menos (Figura 28B), embora não tenha sido observada qualquer diferença estatística. 


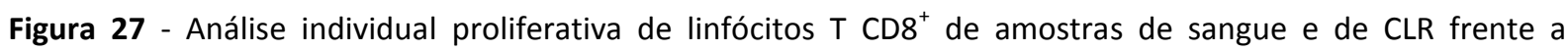
quantidades diferentes de PHA.

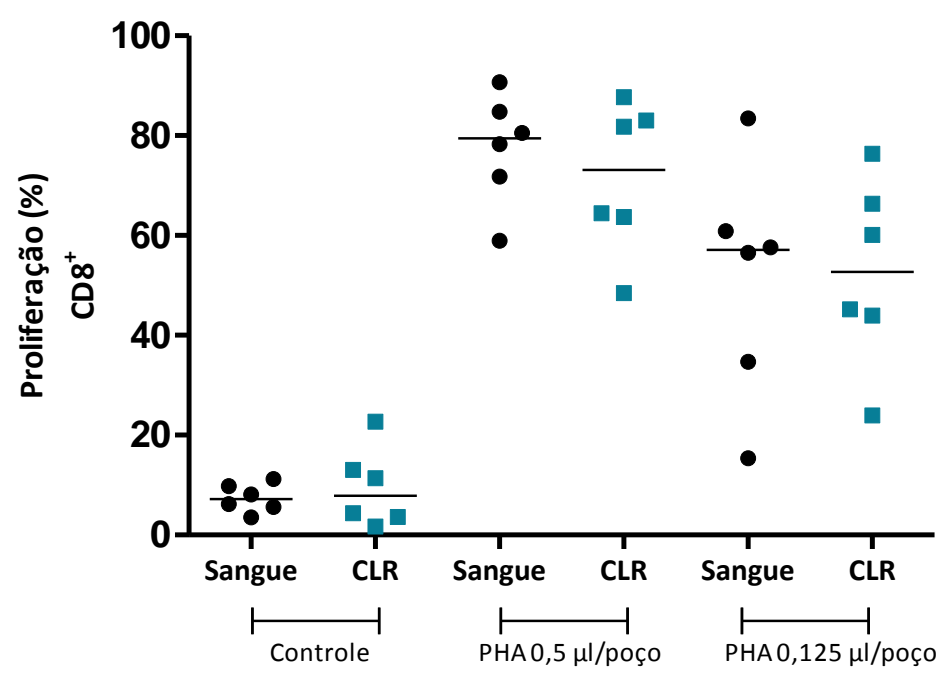

Proliferação de linfócitos $\mathrm{T} \mathrm{CD}^{+}$em amostras de sangue e da CLR em diferentes tratamentos. Controle (sem estímulo): proliferação de 7,2\% \% [IIQ: 5,09; 10,11] em amostras de sangue e de 7,9\% [IIQ: 3,11; 15,44] em

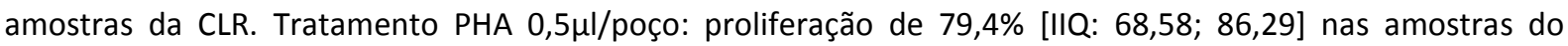
sangue, e de 73,1\% [IIQ: 59,90; 84,23] nas amostras da CLR. Tratamento PHA 0,125 $\mu$ l/poço: proliferação de 57,1\% [IIQ: 29,86; 66,51], para amostras do sangue e 52,7\% [IIQ: 38,99; 68,86] para amostras da CLR. IIQ: Intervalo interquartil; $n=6$; CLR: Câmara de Leucorredução. $p>0,05$ para teste de Wilcoxon.

Figura 28 - Análise individual da correlação da expressão da proliferação de linfócitos T CD8 ${ }^{+}$em amostra de sangue e da CLR.

A

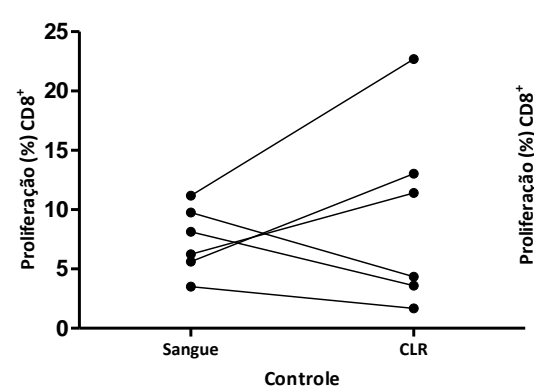

B

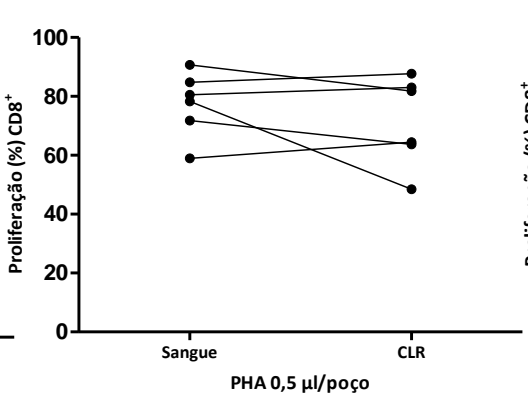

C

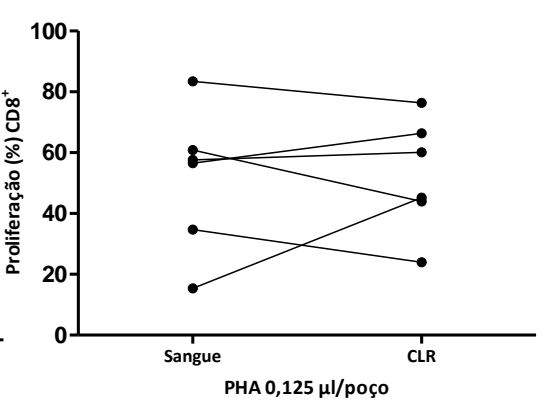

Relação da resposta proliferativa de linfócitos $T \mathrm{CD}^{+}$frente a diferentes tratamentos: (A) controle; (B) PHA 0,5 $\mu \mathrm{l} /$ poço; (C) PHA 0,125 $\mu \mathrm{l} /$ poço; n=6; CLR: Câmara de Leucorredução.

\subsubsection{Análise da produção de citocinas por células do sangue e da CLR in vitro}

Com o objetivo de analisar a capacidade de produção de citocinas pelas células provenientes da CLR em comparação com o sangue, células de ambas as amostras foram estimuladas in vitro com (PHA 0,5 $\mu \mathrm{l} /$ poço e PHA 0,125 $\mu \mathrm{l} /$ poço) e sem estímulo de PHA. 
Para o tratamento controle, a produção de todas as citocinas estudadas estava abaixo do limite de detecção do kit utilizado.

Apesar da predominância na produção de citocinas pró-inflamatórias, foi possível observar a produção da citocina anti-inflamatória IL-10, mas não da IL-4.

A análise das medianas dos grupos mostra a detecção de apenas algumas citocinas nos diferentes tratamentos. Ao analisarmos a produção individual nesses três tratamentos, é possível detectar a produção das citocinas em algumas amostras.

A produção de IL-17A pode ser observada nos dois grupos que receberam estímulos tanto nas amostras de sangue como na da CLR, embora a produção de IL-17A da maioria das células tratadas com 0,125 $\mu \mathrm{L}$ PHA esteja abaixo do limite de detecção (Figura 29A). O

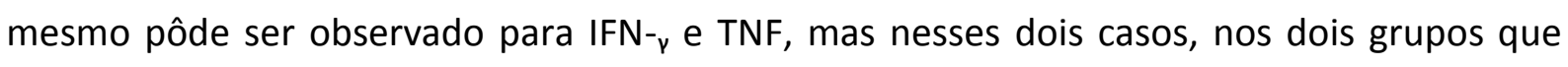
receberam a PHA, a maioria está abaixo do limite de detecção (Figura 29B e C, respectivamente).

IL-10 pôde ser detectada em ambas as amostras (sangue e CLR) nas duas concentrações de estímulo (Figura 29D).

A citocina IL-6 foi a que apresentou maior índice de deteç̧ão nos grupos tratados com estímulo, sendo que em alguns casos, a quantidade de citocina produzida até extrapola o limite de detecção (Figura 29E).

De maneira geral, a produção mediana de IL-2 esteve abaixo do limite de detecção, no entanto, foi observado que nas amostras de sangue há produção nos três grupos, enquanto que nas amostras da CLR, somente o grupo controle apresentou a produção dessa citocinas de forma individual (Figura 29F). 
Figura 29 - Produção de citocinas de amostras do sangue e da CLR.

A

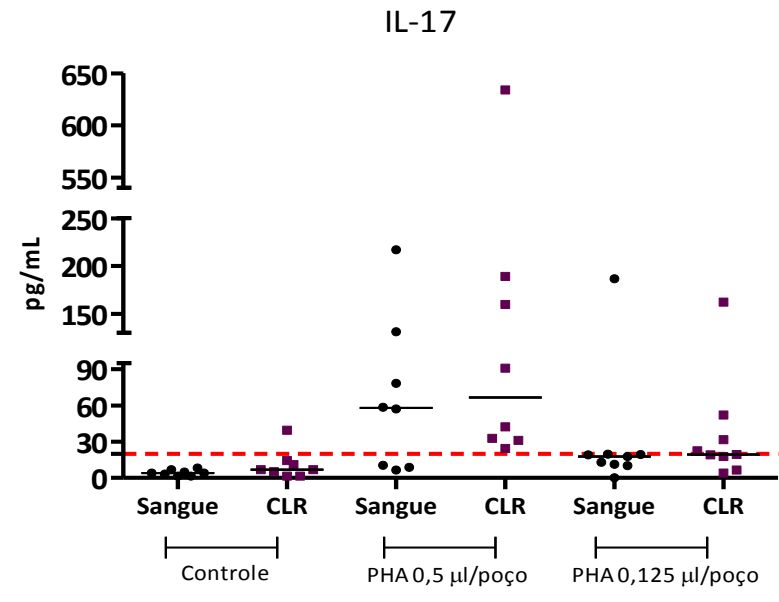

C

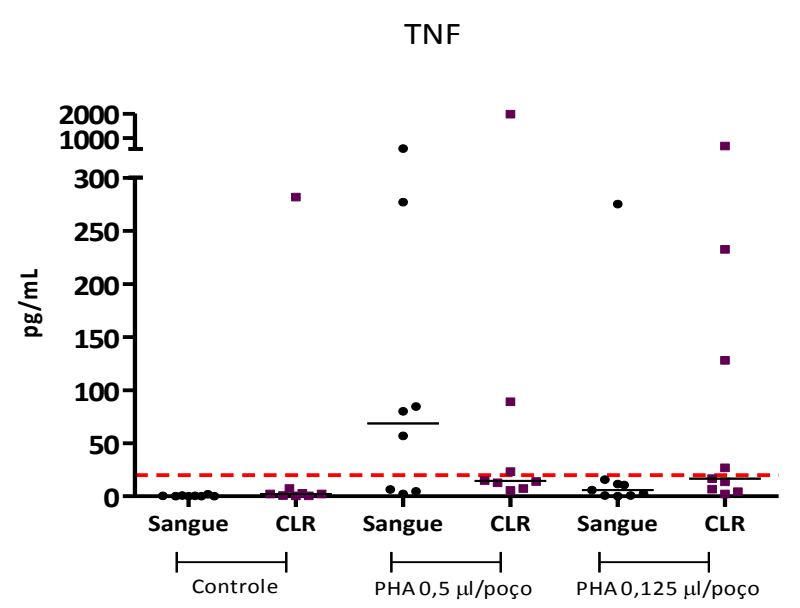

E

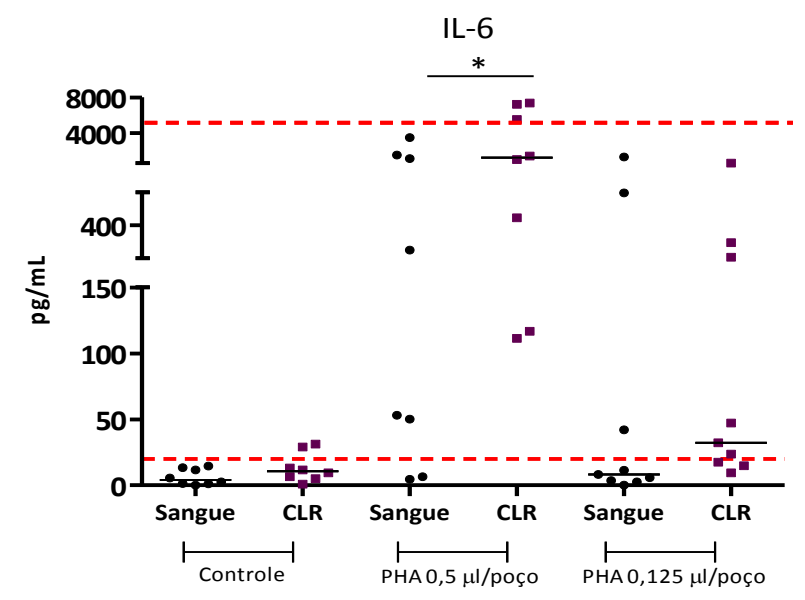

B

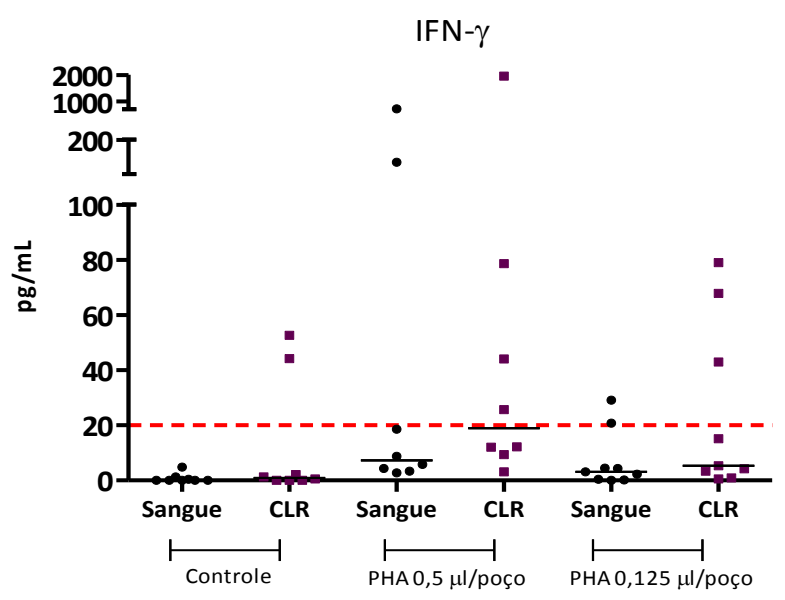

D

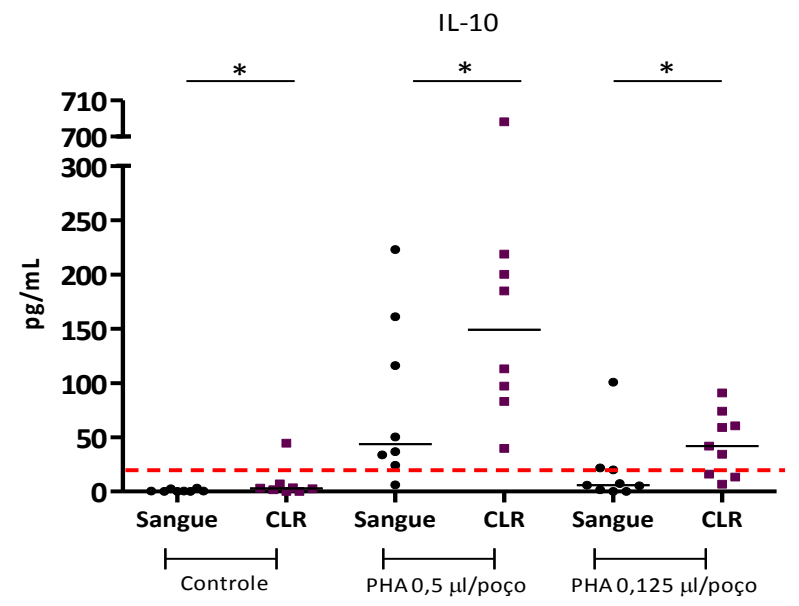

$\mathbf{F}$

IL-2

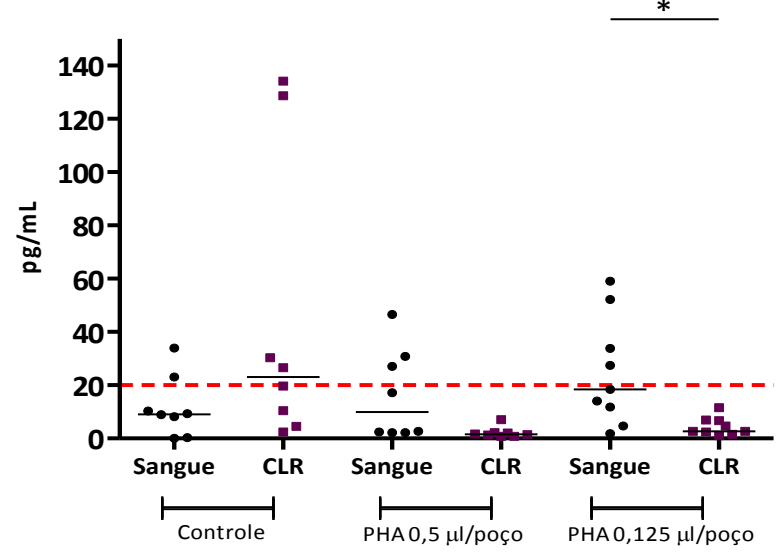

Concentração de IL-17 (A), IFN- ${ }_{-\gamma}(B)$, TNF (C), IL-10 (D), IL-6 (E) e IL-2 (F) em sobrenadante de células mononucleares (de sangue e de CLR) com (PHA 0,5 $\mu \mathrm{l} /$ poço e PHA 0,125 $\mu \mathrm{l} /$ poço) ou sem (controle) estímulo de PHA mantidas em cultura por 48h. CLR: Câmara de Leucorredução. $n$ controle $=8 ; n$ PHA 0,5 $\mu \mathrm{l} /$ poço $=8 ; n$ PHA 0,125 $\mu \mathrm{l} /$ poço $=9 .{ }^{*} p<0,05$ para teste de Wilcoxon. Tracejado vermelho indica limite inferior e superior de deteç̧ão. 


\subsubsection{Avaliação da apoptose espontânea em amostras de sangue e da CLR}

A apoptose espontânea foi avaliada pela expressão de Anexina-V em linfócitos $T$ $\mathrm{CD}^{+}, \mathrm{T} \mathrm{CD} 8^{+}$em linfócitos $\mathrm{B}\left(\mathrm{CD} 19^{+}\right)$analisadas no tempo 0 (zero) e após 2 e $6 \mathrm{~h}$ de cultura sem qualquer estímulo.

Os dados mostram que no tempo 0 , menos de $10 \%$ dos linfócitos T CD4 e T CD8, tanto da CLR como do sangue apresentaram ligação à Anexina-V, mas para essas duas populações, o valor mediano de células Anexina-V ${ }^{+}$é inferior na CLR: 5,4\% [IIQ: 3,95; 9,47] para T CD4 na CLR e 7,5\% [IIQ: 5,75; 8,17] no sangue e nos linfócitos T CD8, 4,2\% [IIQ: 2,29; 7,41] para amostras da CLR e 7,2\% [IIQ: 3,32; 8,20] para amostras do sangue (Figura 30).

Com o passar do tempo em cultura, houve aumento de células em apoptose. A frequência de linfócitos T CD4 ${ }^{+}$aumentou em 2 e $6 \mathrm{~h}$ em ambas as amostras, no entanto, os valores medianos das células nas quais houve ligação de Anexina-V é semelhante no sangue (10,4\%; IIQ: 8,84; 13,77) e na CLR (12,4\%; IIQ: 5,39; 16,52). Em 6h de cultura, houve pequeno aumento de células T CD4 ${ }^{+}$apoptóticas tanto no sangue $(12,6 \%$; IIQ: 10,13; 13,45) como na $\operatorname{CLR}(16,3 \%$; IIQ: 4,91; 18,69) (Figura 30A).

Nos linfócitos T CD8 também foi observado aumento de células apoptóticas com o passar do tempo em cultura. No entanto, é interessante notar que, nos três tempos estudados, a frequências de células $\operatorname{TCD} 8^{+} A$ nexina- $V^{+}$é inferior na $C L R$ quando comparado com o sangue. Nos tempos 0, 2 e 6h, a frequência de células apoptóticas observadas na CLR foi de 4,2\% [IIQ: 2,29; 7,41], 5,4\% [IIQ: 1,89; 7,26] e 4,6\% [IIQ: 1,24; 5,6], respectivamente. Enquanto que nesses mesmos tempos, a frequências de células observadas no sangue foi de 7,2\% [IIQ: 3,32; 8,2], 8,4\% [IIQ: 6,15; 9,88] e 9,6\% [IIQ: 5,1; 10,83], respectivamente (Figura 30B).

Os linfócitos B também apresentaram o mesmo padrão de apoptose, no entanto, a frequência de células apoptóticas no tempo zero foi superior ao observado para os linfócitos T, sendo de $31,9 \%$ [IIQ: 20,$65 ; 50,96$ ] no sangue e $34,8 \%$ [IIQ: 14,$8 ; 77,88$ ] na CLR. Em $2 \mathrm{~h}$ horas de cultura, essa frequência aumentou para 32,9\% [IIQ: 22,36; 49,73] no sangue e 46,9\% [IIQ: 17,16; 72,52] na CLR e, em 6h de cultura, a frequência de células apoptóticas observada foi de $31,1 \%$ [IIQ: 24,$24 ; 63,76$ ] no sangue e $45,7 \%$ [IIQ: 16,$01 ; 73,85$ ] na CLR (Figura 30C). 
Em nenhumas das três subpopulações estudadas observou-se grande diferença na taxa de apoptose entre amostras de sangue e CLR, mostrando que o processo de leucorredução não induz a apoptose das células presentes da CLR.

Figura 30 - Análise da apoptose espontânea em linfócitos T CD4, T CD8 e linfócitos B.
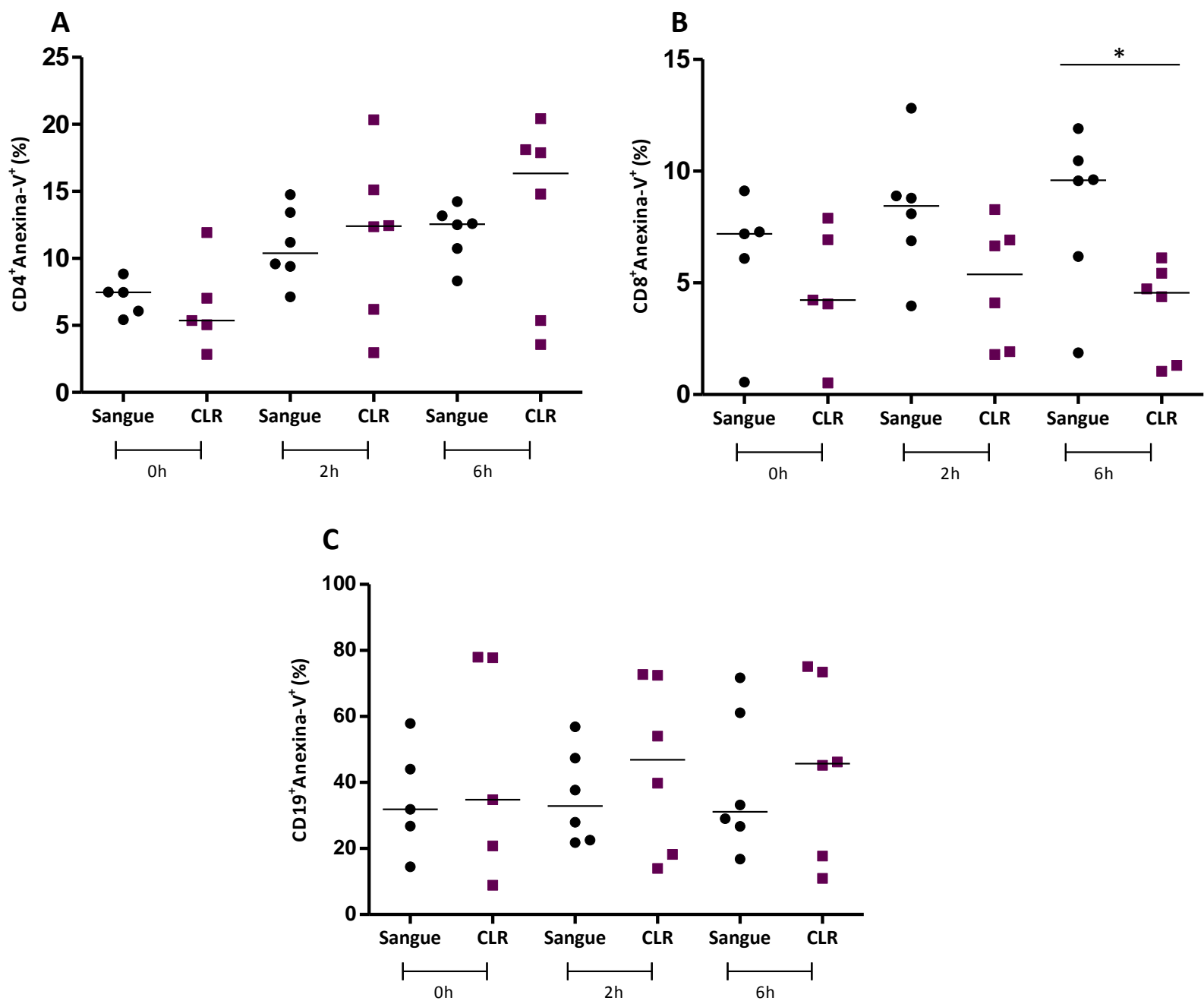

(A) Frequência de células TCD4 ${ }^{+}$Anexina- $\mathrm{V}^{+}$em amostras de sangue e da CLR em tempos diferentes: tempo 0 sendo 7,5\% [IIQ: 5,75; 8,17] no sangue e 5,4\% [IIQ: 3,95; 9,47] na CLR; $2 \mathrm{~h}, 10,4 \%$ [IIQ: 8,$84 ; 13,77]$ no sangue e 12,4\% [IIQ: 5,39; 16,52] na CLR; 6h, 12,6\% [IIQ: 10,13; 13,45] no sangue e 16,3\% [IIQ: 4,91; 18,69] na CLR. No tempo $0 \mathrm{n}=5$ e em 2 e $6 \mathrm{~h} n=6$. IIQ: intervalo interquartil; $\mathrm{CLR}=$ Câmara de Leucorredução. $p>0,05$ para teste de Wilcoxon.

(B) Frequência de células TCD8 ${ }^{+}$Anexina- $\mathrm{V}^{+}$em amostras de sangue e da CLR em tempos diferentes: tempo 0 sendo 7,2\% [IIQ: 3,32; 8,20] no sangue e 4,2\% [IIQ: 2,29; 7,41] na CLR; $2 \mathrm{~h}, 8,4 \%$ [IIQ: 6,15; 9,88] no sangue e 5,4\% [IIQ: 1,$89 ; 7,26]$ na CLR; 6h, 9,6\% [IIQ: 5,1; 10,83] no sangue e 4,6\% [IIQ: 1,$24 ; 5,6]$ na CLR. No tempo 0 $\mathrm{n}=5$ e em 2 e $6 \mathrm{~h} \mathrm{n}=6$. IIQ: intervalo interquartil; $\mathrm{CLR}=$ Câmara de Leucorredução. . * $p<0,05$ para teste de Wilcoxon.

(C) Frequência de células TCD19 ${ }^{+}$Anexina- $\mathrm{V}^{+}$em amostras de sangue e da CLR em tempos diferentes: tempo 0 sendo 31,9\% [IIQ: 20,65; 50,96] no sangue e 34,8\% [IIQ: 14,8; 77,88] na CLR; 2h, 32,9\% [IIQ: 22,36; 49,73] no sangue e 46,9\% [IIQ: 17,16; 72,52] na CLR; 6h, 31,1\% [IIQ: 24,24; 63,76] no sangue e 45,7\% [IIQ: 16,01; 73,85] na CLR. No tempo $0 \mathrm{n}=5$ e em 2 e $6 \mathrm{~h} n=6$. IIQ: Intervalo interquartil. CLR = Câmara de Leucorredução. $p>0,05$ para teste de Wilcoxon. 


\subsection{Recuperação de células-tronco hematopoéticas (CTH) provenientes da Câmara de Leucorredução em comparação com amostras de sangue}

Assim como nas outras populações estudadas, a frequência das CTH no sangue e na CLR foi muito semelhante; no entanto, o número total de células recuperadas foi superior na CLR, conforme observado também para as outras populações.

Quando analisadas a frequência de CTH $\mathrm{CD} 45^{\text {low }} \mathrm{CD} 34^{+}$, dentro do total de linfócitos e monócitos, a mesma foi de $0,1 \%$ tanto nas amostras de sangue [IIQ: 0,$04 ; 0,11]$ como nas amostras de CLR [IIQ: 0,03; 0,13] (Figura 31A).

Em relação à recuperação total dessas células, as amostras provenientes da CLR renderam $0,029 \times 10^{6} \mathrm{cel} / \mathrm{mL}$, enquanto que as amostras provenientes do sangue apresentaram rendimento de apenas $0,001 \times 10^{6} \mathrm{cel} / \mathrm{mL}$ (Figura 31B), extrapolando para o volume total da CLR calculamos que, nas amostras estudadas, existam aproximadamente $0,27 \times 10^{6} \mathrm{CTH}$.

Figura 31 - Análise individual da frequência e do rendimento de células-tronco hematopoéticas $\left(\mathrm{CD} 34^{+} \mathrm{CD} 45^{\text {low }}\right)$ presentes em amostras de sangue e da CLR.

A

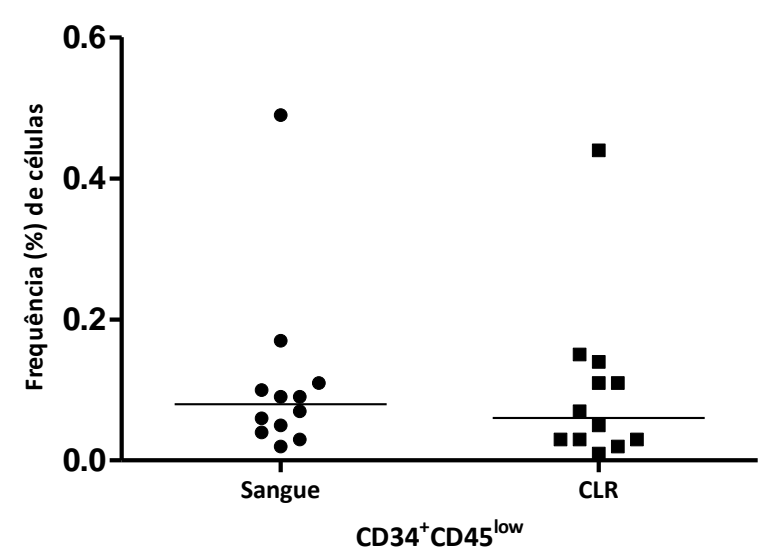

B

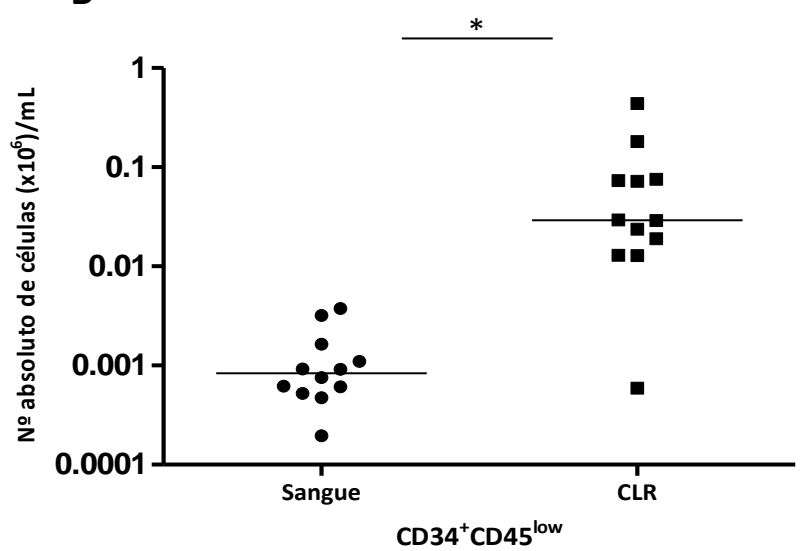

(A) Frequência de CTH, entre os linfócitos e monócitos, em amostras de sangue (0,1\%; IIQ: 0,04; 0,11) e da CLR (0,1\%, IIQ: 0,03; 0,13). IIQ: Intervalo interquartil; $\mathrm{n}=12$; CLR: Câmara de Leucorredução. $p>0,05$ para teste de Wilcoxon.

(B) Rendimento celular médio em amostras de sangue $\left(0,001 \times 10^{6}\right)$ e da CLR $\left(0,029 \times 10^{6}\right)$. Mediana. $n=12 ; C L R$ : Câmara de Leucorredução. ${ }^{*} p<0,05$ para teste de Wilcoxon. 


\subsection{Análise comparativa de doadores de plaquetas frequentes e de 1a vez.}

Considerando os dados contidos no hemograma, em relação ao numero total de leucócitos, linfócitos, monócitos e granulócitos, não foi observada diferença significativa entre amostras de doadores de plaquetas frequentes e de $1^{\text {a }}$ vez. A mediana encontrada para os leucócitos foi de $6,8 \times 10^{6} \mathrm{cel} / \mathrm{mL}$ [IIQ: 5,73; 7,9] nos doadores frequentes e de $6,7 \times 10^{6}$ $\mathrm{cel} / \mathrm{mL}$ [IIQ: 5,05; 9,33] nos doadores de 10 vez (Figura 32A). Para os linfócitos, os valores obtidos foram $1,7 \times 10^{6} \mathrm{cel} / \mathrm{mL}$ [IIQ: 1,$\left.43 ; 2,45\right]$ nos doadores frequentes e de $2,1 \times 10^{6} \mathrm{cel} / \mathrm{mL}$ [IIQ: 1,45; 2,93] nos doadores de primeira vez (Figura 32B). Em relação aos monócitos e granulócitos, os doadores frequentes apresentaram valores medianos de $0,4 \times 10^{6} \mathrm{cel} / \mathrm{mL}$ [IIQ: 0,$3 ; 0,5]$ e $4,35 \times 10^{6} \mathrm{cel} / \mathrm{mL}[\mathrm{IIQ}: 3,8 ; 5,13]$, respectivamente, e os doadores de primeira vez apresentaram $0,5 \times 10^{6} \mathrm{cel} / \mathrm{mL}$ [IIQ: 0,$2 ; 0,85$ ] e $3,9 \times 10^{6} \mathrm{cel} / \mathrm{mL}$ [IIQ: 2,$\left.75 ; 6,1\right]$, respectivamente (Figura $32 \mathrm{C}$ e D).

Das células mononucleares recuperadas de amostras de sangue, foi realizada a análise das subpopulações de linfócitos (T e B), monócitos, células NK e células $C D 3^{+} C D 56^{+}$, baseado nos dados fornecidos pelo hemograma. A mediana dos linfócitos encontrada entre os doadores frequentes foi de $2,08 \times 10^{6} \mathrm{cel} / \mathrm{mL}$ [IIQ: 1,$\left.7 ; 2,41\right]$ e entre os doadores de 1 a vez, este valor foi de $2,3 \times 10^{6} \mathrm{cel} / \mathrm{mL}$ [IIQ: 1,64; 3,37] (Figura 33).

Analisando as subpopulações de linfócitos T, foi observado que em doadores frequentes, há aproximadamente $1,26 \times 10^{6} \mathrm{cel} / \mathrm{mL}$ [IIQ: 0,$\left.94 ; 1,64\right]$ de linfócitos $\mathrm{T} \mathrm{CD}^{+}$e nos doadores de 1 a vez, há aproximadamente $1,84 \times 10^{6} \mathrm{cel} / \mathrm{mL}$ [IIQ: 1,19; 2,56] dessa mesma população (Figura 34A). Para os subtipos de linfócitos $\mathrm{T} \mathrm{CD3}^{+}$, foi observado em doadores frequentes o valor mediano de $0,87 \times 10^{6} \mathrm{cel} / \mathrm{mL}$ [IIQ: 0,$\left.56 ; 1,17\right]$ de linfócitos $T$ CD4 ${ }^{+}$e

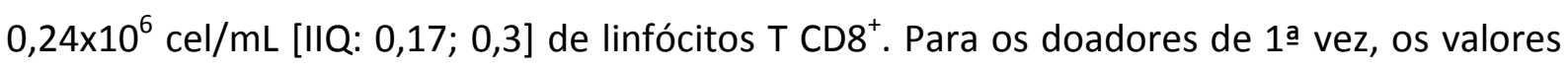
medianos encontrados para essas mesmas populações foram de $1,05 \times 10^{6} \mathrm{cel} / \mathrm{mL}$ [IIQ: 0,76; 2,03] de linfócitos $\mathrm{T} \mathrm{CD}^{+}$e de $0,52 \times 10^{6} \mathrm{cel} / \mathrm{mL}$ [IIQ: 0,$\left.28 ; 0,69\right]$ de linfócitos $\mathrm{T} \mathrm{CD8}{ }^{+}$(Figura 34B e C). 
Figura 32 - Análise comparativa dos leucócitos e suas principais populações em doadores de plaquetas frequentes e de primeira vez.

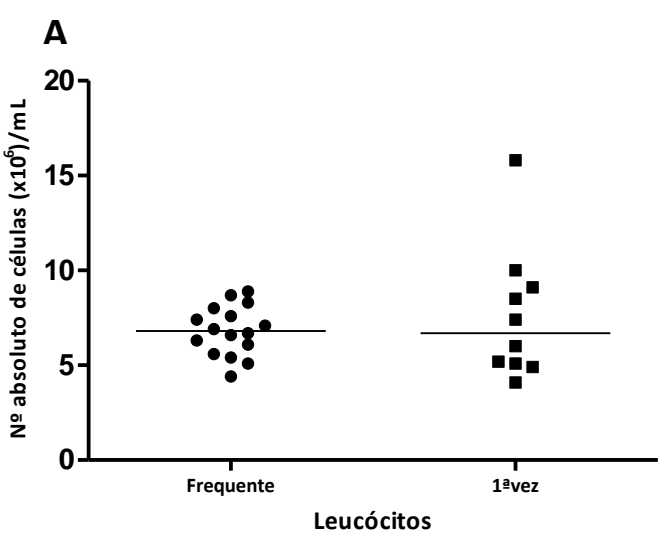

C

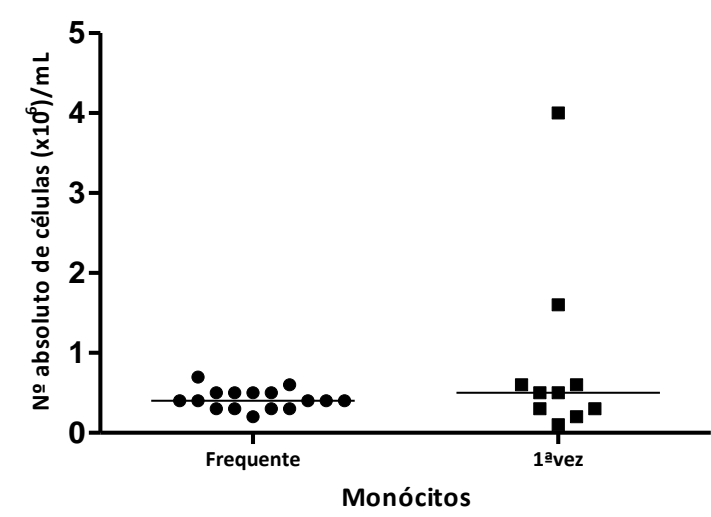



D

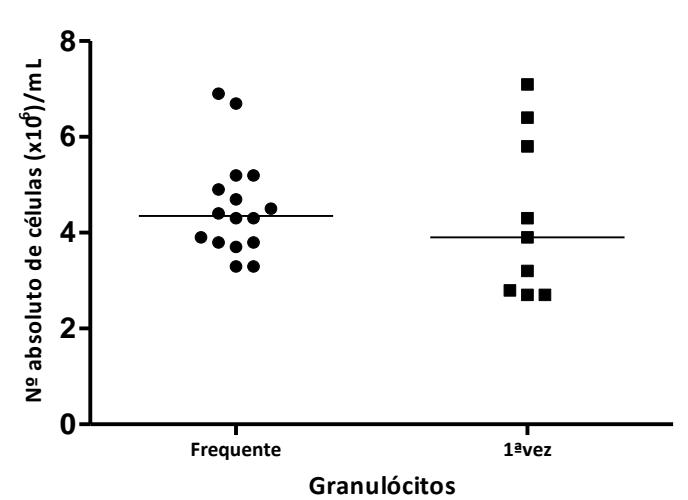

(A) Número de leucócitos de doadores frequentes $\left(6,8 \times 10^{6} \mathrm{cel} / \mathrm{mL} ; \mathrm{IIQ}: 5,73 ; 7,9\right)$ e de $1^{\text {a }}$ vez $\left(6,7 \times 10^{6} \mathrm{cel} / \mathrm{mL}\right.$; IIQ: 5,$05 ; 9,33)$. $n$ doadores frequentes $=16 ; n$ doadores de 1 a vez $=10$. IIQ: Intervalo interquartil. $p>0,05$ para teste de Mann-Whitney.

(B) Número de linfócitos de doadores frequentes $\left(1,7 \times 10^{6} \mathrm{cel} / \mathrm{mL} ; \| \mathrm{IQ}: 1,43 ; 2,45\right)$ e de 1 a vez $\left(2,1 \times 10^{6} \mathrm{cel} / \mathrm{mL}\right.$; IIQ: 1,$45 ; 2,93)$. $n$ doadores frequentes $=16 ; \mathrm{n}$ doadores de 1 a vez $=10 . p>0,05$ para teste de Mann-Whitney.

(C) Número de monócitos de doadores frequentes $\left(0,4 \times 10^{6} \mathrm{cel} / \mathrm{mL} ; \mathrm{IIQ}: 0,3 ; 0,5\right)$ e de 1 a vez $\left(0,5 \times 10^{6} \mathrm{cel} / \mathrm{mL}\right.$; IIQ: 0,$2 ; 0,85)$. $n$ doadores frequentes $=16 ; n$ doadores de 1 a vez $=10$. IIQ: intervalo interquartil. $p>0,05$ para teste de Mann-Whitney.

(D) Número de granulócitos de doadores frequentes $\left(4,35 \times 10^{6} \mathrm{cel} / \mathrm{mL}\right.$; IIQ: 3,$\left.8 ; 5,13\right)$ e de 1 a vez $\left(3,9 \times 10^{6}\right.$ $\mathrm{cel} / \mathrm{mL}$; IQ: 2,$75 ; 6,1) . \mathrm{n}$ doadores frequentes $=16 ; \mathrm{n}$ doadores de 1 a vez $=10$. IIQ: Intervalo interquartil. $p=n s$ para teste de Mann-Whitney. 
Figura 33 - Análise comparativa de linfócitos recuperados, por gradiente de densidade (Ficoll), de amostras de sangue e da CLR de doadores frequentes e de 1 á vez.



Análise comparativa dos linfócitos de doadores frequentes $\left(2,08 \times 10^{6} \mathrm{cel} / \mathrm{mL}\right.$; II: 1,$\left.7 ; 2,41\right)$ e de 1 a vez $\left(2,3 \times 10^{6}\right.$ $\mathrm{cel} / \mathrm{mL}$; IIQ: 1,$64 ; 3,37)$. $\mathrm{n}$ doadores frequentes $=16 ; \mathrm{n}$ doadores de 1 a vez $=10$. IIQ: Intervalo interquartil. p>0,05 para teste de Mann-Whitney.

Figura 34 - Análise comparativa de linfócitos T recuperados, por gradiente de densidade (Ficoll), de amostras de sangue e da CLR de doadores frequentes e de 1 à vez.
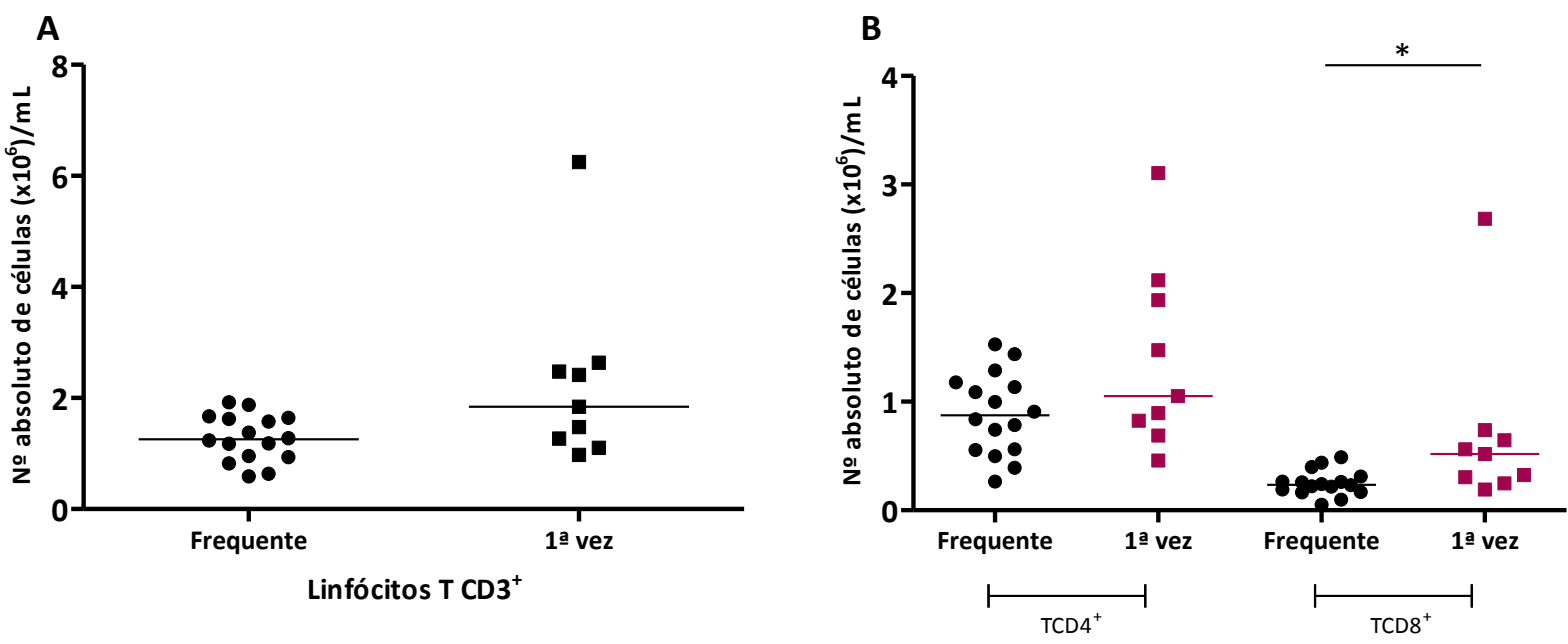

(A) Análise comparativa dos linfócitos T CD3+ de doadores frequentes $\left(1,26 \times 10^{6} \mathrm{cel} / \mathrm{mL}\right.$; IIQ: 0,$\left.94 ; 1,64\right)$ e de 1 a vez $\left(1,84 \times 10^{6} \mathrm{cel} / \mathrm{mL}\right.$; IQ: $\left.\| \mathrm{Q}: 1,19 ; 2,56\right)$. $\mathrm{n}$ doadores frequentes $=16 ; \mathrm{n}$ doadores de $1^{\mathrm{a}}$ vez $=10$. $\| \mathrm{Q}$ : intervalo interquartil. $p>0,05$ para teste de Mann-Whitney.

(B) Análise comparativa dos linfócitos T CD4 ${ }^{+}$de doadores frequentes $\left(0,87 \times 10^{6} \mathrm{cel} / \mathrm{mL}\right.$; IIQ: 0,56; 1,17) e de 1a vez $\left(1,05 \times 10^{6} \mathrm{cel} / \mathrm{mL}\right.$; IIQ: 0,$\left.76 ; 2,03\right)$; e dos linfócitos $T$ CD8 ${ }^{+}: 0,24 \times 10^{6} \mathrm{cel} / \mathrm{mL}$ [IIQ: 0,$\left.17 ; 0,3\right]$ para doadores frequentes e $0,52 \times 10^{6} \mathrm{cel} / \mathrm{mL}$ [IIQ: 0,$\left.28 ; 0,69\right]$ para doadores de 1 a vez. $n$ doadores frequentes $=16 ; n$ doadores de 1 a vez $=10$. IIQ: Intervalo interquartil. ${ }^{*} p<0,05$ para teste de Mann-Whitney 
O estudo dos linfócitos B mostrou valores medianos praticamente idênticos entre os grupos estudados $\left(0,27 \times 10^{6} \mathrm{cel} / \mathrm{mL}\right.$ [IIQ: 0,$\left.2 ; 0,37\right]$ e $0,26 \times 10^{6} \mathrm{cel} / \mathrm{mL}[I I Q: 0,2 ; 0,29]$ para doadores frequentes e de 1a vez respectivamente) (Figura 35A). Também não foi observada alteração significante entre os grupos para população de monócitos, células NK e células $\mathrm{CD}^{+} \mathrm{CD} 56^{+}$, cujos valores medianos também foram próximos. Analisando a população de

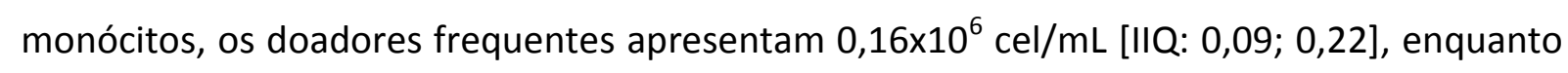
que os doadores de 1 a vez apresentam $0,23 \times 10^{6} \mathrm{cel} / \mathrm{mL}$ [IIQ: 0,$1 ; 0,31$ ] (Figura 35B). Por sua vez, esses dois grupos apresentam, respectivamente, $0,26 \times 10^{6} \mathrm{cel} / \mathrm{mL}$ [IIQ: 0,$2 ; 0,36$ ] e

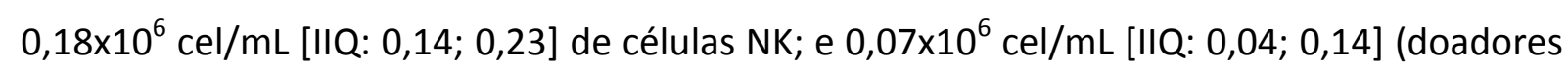
frequentes) e $0,12 \times 10^{6} \mathrm{cel} / \mathrm{mL}$ [IIQ: 0,06; 0,19] (doadores de 1ạ vez) de células $\mathrm{CD}^{+} \mathrm{CD}^{\circ} 6^{+}$. 
Figura 35 - Análise comparativa de linfócitos B, monócitos, células NK e Células $C D 3^{+} C D 56^{+}$recuperados, por gradiente de densidade (Ficoll), de amostras de sangue e da CLR de doadores frequentes e de $1^{\underline{a}}$ vez.
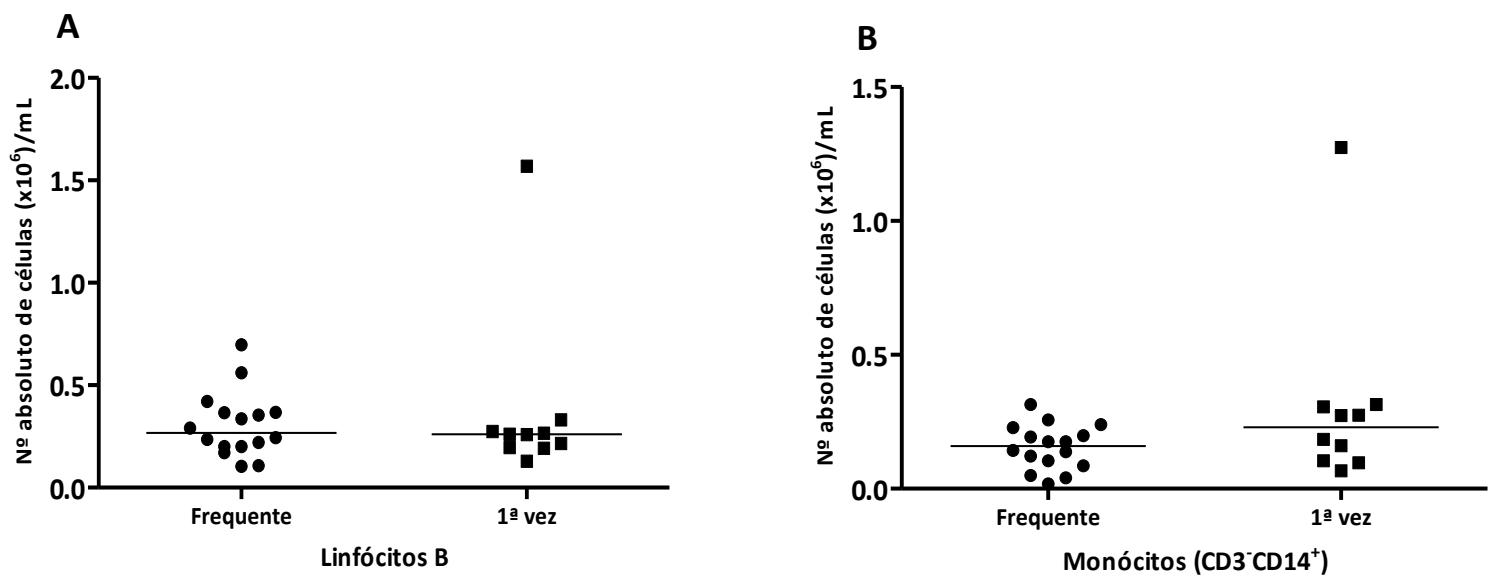

C

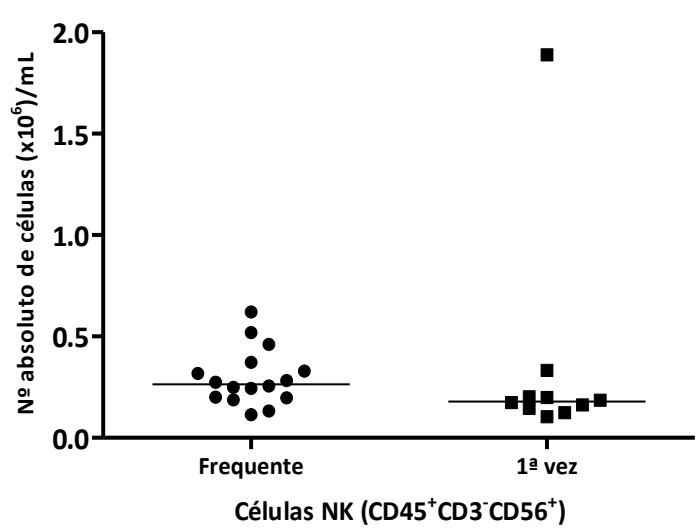

D

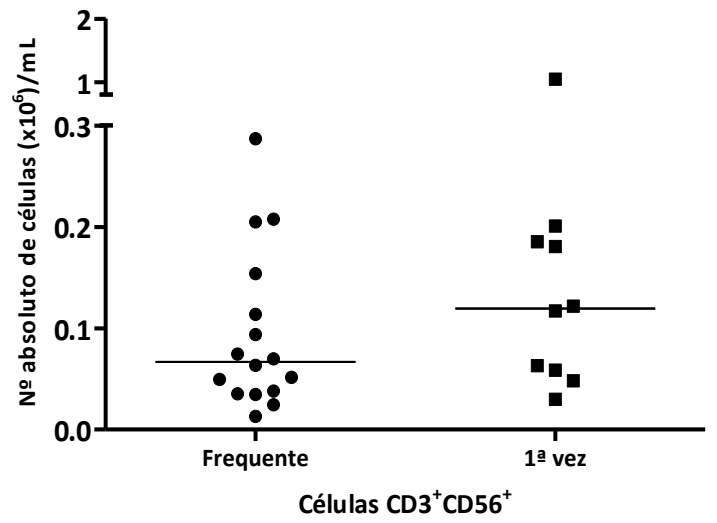

(A) Análise comparativa dos linfócitos $B$ de doadores frequentes $\left(0,27 \times 10^{6} \mathrm{cel} / \mathrm{mL} ; 0,2 ; 0,37\right)$ e de 1 a vez $\left(0,26 \times 10^{6} \mathrm{cel} / \mathrm{mL} ; \| \mathrm{Q}: 0,2 ; 0,29\right) . \mathrm{n}$ doadores frequentes $=16 ; \mathrm{n}$ doadores de 1 a vez $=10$. IIQ: Intervalo interquartil. $p>0,05$ para teste de Mann-Whitney.

(B) Análise comparativa dos monócitos de doadores frequentes $\left(0,16 \times 10^{6} \mathrm{cel} / \mathrm{mL} ;\right.$ IIQ: 0,09; 0,22) e de 1 a vez $\left(0,23 \times 10^{6} \mathrm{cel} / \mathrm{mL} ; \mathrm{IIQ}: 0,1 ; 0,31\right)$. $\mathrm{n}$ doadores frequentes $=16 ; \mathrm{n}$ doadores de 1 a vez $=10$. IIQ: intervalo interquartil. $p>0,05$ para teste de Mann-Whitney.

(C) Análise comparativa das células NK de doadores frequentes $\left(0,26 \times 10^{6} \mathrm{cel} / \mathrm{mL} ;\right.$ IIQ: 0,$\left.2 ; 0,36\right)$ e de $1^{\text {a }}$ vez $\left(0,18 \times 10^{6} \mathrm{cel} / \mathrm{mL} ; \mathrm{IIQ}: 0,14 ; 0,23\right)$. $\mathrm{n}$ doadores frequentes $=16 ; \mathrm{n}$ doadores de $1 \underline{a}$ vez $=10$. IIQ: Intervalo interquartil. $p>0,05$ para teste de Mann-Whitney.

(D) Análise comparativa das células $\mathrm{CD}^{+} \mathrm{CD}^{+} 6^{+}$de doadores frequentes $\left(0,07 \times 10^{6} \mathrm{cel} / \mathrm{mL}\right.$; IIQ: 0,$\left.04 ; 0,14\right)$ e de 1a vez $\left(0,12 \times 10^{6} \mathrm{cel} / \mathrm{mL} ; \| Q: 0,06 ; 0,19\right) \mathrm{n}$ doadores frequentes $=16 ; \mathrm{n}$ doadores de 1 a vez $=10$. $\| \mathrm{Q}:$ Intervalo interquartil. $p>0,05$ para teste de Mann-Whitney. 


\section{DISCUSSÃO}

A maioria dos estudos envolvendo a recuperação de células provenientes de subprodutos descartados da doação de sangue utiliza os filtros de leucorredução, que são utilizados após uma doação de sangue total para posterior separação dos diferentes hemocomponentes. Esses estudos mostram que os filtros são uma fonte viável de leucócitos e que é possível recuperar grande quantidade de células $(48,50,51)$. No entanto, o acesso a esses filtros pode demorar uma vez que, ao final da doação de sangue total, este ainda precisa ser processado para obtenção dos componentes sanguíneos, e só então o filtro estará disponível para uso. Além disso, para obter as células presas nos filtros é preciso realizar uma série de lavagens $(50,51,62)$. As CLR por sua vez, estão liberadas para o uso logo ao término da doação por aférese e seu conteúdo pode ser manuseado como sangue total (na separação das células mononucleares), o que facilita e torna o processo mais ágil.

O rendimento celular recuperado nas CLR foi em média 77 vezes maior que o rendimento para amostras de sangue considerando volumes iguais. O número total de células recuperadas $\left(1,05 \times 10^{9}\right)$ é semelhante ao encontrado em outros trabalhos $(45,46)$, no entanto, a maior parte dos trabalhos compara o rendimento da CLR com o rendimento dos filtros de leucorredução; a comparação foi realizada com amostras de sangue de volume próximo ao encontrado da CLR. Steininger e colaboradores (2013) (55) mostraram que o sistema da Câmara de Leucorredução também pode ser ajustado para coletar diretamente os leucócitos, obtendo um rendimento celular superior ao observado no presente trabalho $\left(5,26 \times 10^{9} \pm 2,2 \times 10^{9}\right.$ de células $\left.C D 45^{+}\right)$. Apesar de a metodologia utilizada ter sido diferente, uma vez que o sistema de aférese foi utilizado para separação dos leucócitos, os resultados mostram a viabilidade desse sistema automatizado de aférese para obtenção de leucócitos para uso de pesquisa ou uso terapêutico. No entanto, a utilização da CLR resultante da doação de plaqueta é mais vantajosa, uma vez que se trata de um subproduto que seria descartado e não seria necessário submeter o doador ao procedimento de aférese exclusivamente para fins de pesquisa.

Outro fator a ser levado em conta é o tipo do aparelho usado na doação por aférese, bem como a configuração do mesmo, pois pode resultar em recuperação celular diferente das $\operatorname{CLR}(63,64)$. No presente trabalho, todas as doações foram realizadas com o Trima Accel $^{\mathrm{TM}}$ (Gambro BCT, Lakewood, Colorado, Estados Unidos), o que minimiza as variações 
causadas pelo uso de diferentes aparelhos de coleta automatizada de plaquetas. Nerón e colaboradores (2007) notaram maior rendimento celular nas CLR que passaram por doações duplas $\left(0,7 \times 10^{9}\right.$ para doações simples e $0,9 \times 10^{9}$ para doações duplas), e o mesmo também foi observado no presente trabalho, em que a correlação entre o produto coletado e o rendimento da CLR foi positiva (APÊNDICE B).

Estudos mostram que células provenientes da CLR podem ser isoladas sem alterar as propriedades dessas células, sem interferência no estado de ativação das mesmas $(45,65)$. Recentemente, Pfeiffer e colaboradores (2013) (65) isolaram linfócitos B, T CD4 e T CD8 utilizando a técnica de beads magnéticas, alcançando rendimento de $12 \times 10^{6} \pm 4 \times 10^{6}$; $83 \times 10^{6} \pm 20 \times 10^{6}$ e $56 \times 10^{6} \pm 1 \times 10^{6}$, respectivamente. Para essas mesmas populações, a mediana aqui estimada foi de $71,3 \times 10^{6}$ para os linfócitos $B ; 260,3 \times 10^{6}$ para as células $\mathrm{T}^{\mathrm{CD}} 4^{+}$e $103,4 \times 10^{6}$ para as $\mathrm{T} \mathrm{CD8}^{+}$. Embora este seja apenas um número estimado, e que habitualmente ocorrem perdas nos processos de isolamento, fica claro que nas CLR há células suficientes para serem isoladas e utilizadas em diferentes ensaios, e em quantidades equivalentes às que seriam encontradas em grandes volumes de sangue. As células utilizadas por Pfeiffer e colaboradores para separação dos linfócitos $T$ foram células congeladas, e o número total observado no presente trabalho mostra que células a fresco têm potencial para maior rendimento após a separação, uma vez que no processo de congelamento pode ocorrer perda quantitativa e qualitativa das células.

Estudos já mostraram que a frequência leucocitária presente nos filtros de leucorredução é similar aquela encontrada no sangue $(51,62,66,67)$, e que a frequência de células mononucleares presentes da CLR é semelhante à frequência nos filtros (45). Entretanto, até o momento, não havia comparação direta entre a frequência das principais populações leucocitárias presentes na CLR e no sangue. Nós observamos que as frequências de linfócitos T CD3, T CD4, T CD8, linfócitos B, células NK e monócitos se apresentaram de forma semelhante entre amostras de sangue e da CLR, mostrando que o processo de leucorredução não interfere na composição de células mononucleares presente na CLR, reforçando o indício de que esta pode ser uma importante fonte dessas populações celulares.

Células dendríticas derivadas de monócitos são largamente utilizadas, no entanto, uma quantidade considerável de monócitos deve ser isolada para esse fim (63). Visto que as células dendríticas são encontradas em pequenas quantidades no sangue, tanto os filtros 
quanto as CLR se mostraram uma fonte importante de monócitos para essa finalidade (45, $65,68)$. A quantidade de monócitos que encontramos $\left(13,2 \times 10^{6} \mathrm{cel} / \mathrm{mL}\right.$ - Tabela 5$)$ confirma a possibilidade da utilização das CLR para obtenção de monócitos para este propósito. Além de monócitos, linfócitos B têm sido isolados das CLR para os mais diferentes fins, como a diferenciação em plasmócitos para o estudo de diferentes clones de anticorpos monoclonais (69), confirmando assim o potencial das Câmaras de Leucorredução como fonte alternativa ao sangue para obtenção de leucócitos para uso em diferentes objetivos.

O perfil de ativação de linfócitos T, analisados pela expressão de CD69, CD122, CD25, e dos linfócitos B, analisados pela expressão de CD69 foi semelhante tanto nas amostras de sangue como nas amostras da CLR. Apesar de serem proteínas de membranas relacionadas com ativação celular, a baixa expressão de CD25 e CD122 é importante para sobrevivência dos linfócitos (70), e justamente uma baixa expressão desses receptores foi observada nas amostras estudadas. $\mathrm{O}$ fato de estes receptores celulares estarem presentes na CLR em frequências semelhantes às do sangue é mais um indício de que, durante o processo de leucorredução, não há interferência na expressão dos mesmos. Essa observação mostra que, assim como as células do sangue pode sem usados em diversos estudos, as células provenientes da CLR também poderiam ser utilizadas para o mesmo fim.

É interessante notar, que células com perfil fenotípico de memória (CD45RO ${ }^{+}$) tendem a aumentar com o avançar da idade $(71,72)$ e realmente isso é observado nos linfócitos TCD4, mas não nos linfócitos TCD8, em que a frequência de células $C D 45 R A^{+}$é maior que a frequência das células $\mathrm{CD} 45 \mathrm{RO}^{+}$. Essa diferença de células naïves e de memória entre os linfócitos T CD4 e T CD8 já foi observada anteriormente. Cossarizza e colaboradores (1996) (73) viram que na vida adulta, aproximadamente $20 \%$ das células T CD4 são naïves, enquanto que para os linfócitos T CD8, mais ou menos 50\% estão nessa condição. Apesar da diferença estatística observada entre amostras do sangue e da CLR para essa condição, tanto as células $\mathrm{T} \mathrm{CD}^{+}$e $\mathrm{T} \mathrm{CD} 8^{+}$estão dentro desse range de normalidade em relação à expressão dessas proteínas.

Apesar das isoformas de CD45 serem utilizados como marcadores clássicos para caracterização de células naïve e de memória, para melhor caracterização dessas células, e para avaliar de forma mais precisa a amostra proveniente da CLR, seria interessante utilizar outros marcadores relacionados com o estado de diferenciação dessas células, como CD62L, CCR7, CD27 e CD28, que além de caracterizar essas células como naïves e de memória, 
também permitiriam diferenciar se a célula está num processo ativação primária intermediária ou tardia $(19,21,74)$. Essa percepção do perfil do linfócito T seria mais uma ferramenta para averiguar se o processo de leucorredução altera o perfil dos linfócitos de forma mais sutil, embora com os resultados obtidos, pareça não haver alterações importantes nas células devido a esse processo.

Estudos já mostraram que as células recuperadas da CLR são passíveis de ativação. Dietz e colaboradores (2006) (45) mostraram que células $\mathrm{CD}^{+}, \mathrm{CD}^{+}, \mathrm{CD} 19^{+}$, células NK e CD14 ${ }^{+}$provenientes de CLR apresentam maior expressão de CD25 e CD69 quando estimuladas com Staphylococcal enterotoxin (SBE). Outros estudos mostram que células provenientes dos filtros de leucorredução também são capazes de serem ativadas com outros estímulos $(49,51)$. No presente trabalho, nós testamos o potencial proliferativo das células $\mathrm{T} \mathrm{CD}^{+}$e $\mathrm{CD} 8^{+}$frente ao estímulo da PHA e observamos que assim como no sangue, as células da CLR responde a esse estímulo, proliferando em concentrações ótimas de estímulo, como também em concentrações inferiores. Apesar não termos avaliado a expressão de moléculas características de ativação celular, a proliferação já um indicativo do potencial funcional dessas células.

Os ensaios funcionais, de maneira geral, mostraram que as células recuperadas da CLR, assim como as células recuperadas do sangue, respondem a estímulos. $O$ ensaio de proliferação mostrou que as células da CLR não se tornam mais ou mesmo sensíveis aos estímulos devido ao estresse físico que elas possam ter sofrido durante o processo de elutriação uma vez que responderam, de forma comparável ao sangue, a concentrações ótimas e baixas de estímulo. Embora as células da CLR tenham proliferando em menor concentração de PHA, nessa mesma concentração $(0,125 \mu \mathrm{l} /$ poço) foi detectada somente a produção de IL-10 e IL-6, diferente da concentração ótima de PHA, em que além dessas, foi observada também a produção de IL-17A. Pfeiffer e colaboradores (65) observaram também a produção de IL-2, a qual não foi detectada por nós. Essa não detecção de IL-2 pode ser devido ao consumo dessa citocina pelas próprias células da cultura, uma vez que ela é importante para ativação/proliferação dos linfócitos T e B. O estudo da apoptose também não mostrou diferença entre células do sangue e da CLR. Baixa frequência de apoptose em células da CLR também foi observada por Weidinger e colaboradores (64), que viram diferença significativa somente após de $48 \mathrm{~h}$ de cultura, tanto para os linfócitos como para os monócitos, mais uma vez confirmando a viabilidade dessas células. Aqui, foi possível 
observar que as células $B$ apresentam maior frequência de células Anexina- $\mathrm{V}^{+}$que os linfócitos T. Mas, apesar desse índice basal de apoptose ser elevado, observamos que as células B da CLR tem o valor mediando de apoptose mais elevado em relação ao sangue que os linfócitos T. Isso poderia ser uma sugestão do motivo da diminuição da frequência de linfócitos B observada, uma vez que parecem estar morrendo mais que as células do sangue.

Todas essas análises são importantes para comprovar a viabilidade das células provenientes da CLR, uma vez que o processo de aférese provoca estresse oxidativo nas células do sangue (75), o que influenciaria na funcionalidade das mesmas. Mas os resultados mostram que as células da CLR permanecem com suas capacidades funcionais preservadas. Strasser e colaboradores (2011) (76), também mostraram que o conteúdo da CLR pode ser armazenado em bolsa de PVC até 24 horas após o procedimento de aférese, sem expressar maior índice de células apoptóticas ou necróticas, quando comparadas com as células utilizadas logo após a aférese. Assim, o conteúdo da CLR pode ser armazenado (como o sangue total), para posterior manipulação.

As células-tronco hematopoéticas (CTH) são de extrema importância, pois mantém a quantidade de células sanguíneas adultas circulantes em quantidades necessárias para homeostasia do organismo, no entanto, sua concentração no sangue é baixa, fato que dificulta a obtenção dessas células para uso em terapias. As fontes de CTH comumente usadas incluem a medula óssea e o sangue do cordão umbilical, porém, o processo para obtenção de CTH da medula óssea é um processo invasivo, o que restringe esse procedimento. $\mathrm{O}$ sangue do cordão umbilical também pode ser usado como fonte de $\mathrm{CTH}$, mas a quantidade obtida é pequena, o que limita sua utilização terapêutica a crianças (77). Outra maneira de se obter células $\mathrm{CD}_{3} 4^{+}$é através da mobilização das mesmas para o sangue, mas essa técnica é preferencialmente utilizada em pacientes. Em doadores saudáveis a mobilização de CTH com fatores de crescimento (G-CSF) pode causar dores nos ossos e dores de cabeça (78).

A frequência dessas células do sangue é muito baixa, assim, fontes alternativas de CTH são necessárias para uso em pesquisa. Estudos mostram que os filtros de leucorredução contém $\mathrm{CTH}$, mostrando ser uma fonte importante dessas células uma vez que amostras provenientes do mesmo doador podem ser congeladas a fim de se obter um pool de células (77), o que não pode ser realizado com células provenientes de sangue de cordão, por 
exemplo. Logo, uma vez que é possível extrair grandes quantidades de leucócitos dos filtros de leucorredução (79), seria também possível obter CTH das Câmaras de Leucorredução.

A frequência de $\mathrm{CTH}$, dentre as células mononucleares, encontradas tanto em amostras da CLR como nas amostras de sangue, foi de $0,1 \%$, frequência semelhante à encontrada em filtros de leucorredução (0,16\%) (79). Embora Peytour e colaboradores (47) tenham observado frequências menores de CTH provenientes de filtros de leucorredução, os dados mostram que a frequência de CTH nas CLR é compatível com a observada no sangue.

A mediana de células $\mathrm{CD} 34^{+}$totais $\left(\mathrm{CD} 34^{+} \mathrm{CD} 45^{\text {low }}\right)$ encontradas nas CLR foi de aproximadamente $0,029 \times 10^{6} \mathrm{cel} / \mathrm{mL}$, concentração muito superior à encontrada em amostras de sangue $\left(0,001 \times 10^{6} \mathrm{cel} / \mathrm{mL}\right)$ (Fig. 31B). Trabalhos envolvendo os filtros de leucorredução, com posterior separação dessas células, são divergentes em relação ao rendimento celular, enquanto em alguns foi observado rendimento semelhante (77), em outros o rendimento foi inferior ao observado no presente trabalho (79). 0 intervalo do rendimento celular obtido neste trabalho $\left(0,001\right.$ a $3,8 \times 10^{6}$ células) é compatível com dados encontrados da literatura que também utilizaram a CLR (46), mostrando que as CLR podem ser uma fonte viável de CTH, no entanto, outros estudos ainda são necessários para confirmar a funcionalidade das células que identificamos na CLR, bem como a viabilidade técnica para seu isolamento.

A doação frequente de plaquetas por aférese permite intervalos entre as doações inferiores àqueles permitidos para doação de sangue convencional (sangue total). 0 intervalo entre as doações é de 48 horas, sendo permitidas no máximo 24 doações/ano. Como mostrado neste trabalho, no interior da CLR ficam retidas aproximadamente $1,4 \times 10^{9}$ células mononucleares (Tabela 4), assim, é importante estudar se essa perda provoca alguma alteração significativa na população leucocitária dos doadores frequentes de plaquetas, visto que a maior parte dos estudos que abordam o tema são estudos antigos ou visam a avaliação de reações no momento da doação, como tonturas e outros.

Estudos que compararam leucócitos pré e pós aférese observaram diferenças significativas entre esses dois momentos $(36,80,81)$, no entanto, isso já era de se esperar, visto que nos modelos antigos de aférese, as plaquetas coletadas vinham contaminadas com leucócitos $(81,82)$ e, nos modelos atuais de doação de plaquetas por aférese, o grau de pureza do produto é alto. Rock e colaboradores (1992) (80) observaram alteração no numero total de leucócitos, no entanto, essa alteração foi transitória e, antes do final das 
doações (foram realizadas 10 doações em um período de 22 dias), e em 7 dias após essa última doação, o número de células brancas já estava reestabelecido, mesmo tendo usado um modelo em que a frequência de doações era maior que a recomendada (máximo de 2 doações/semana e no estudo foram realizadas 3 doações/semana). Sekhar Das e colaboradores (2009) e Beyan e colaboradores (2003) (81, 83), compararam não só os valores de leucócitos pré e pós aférese, mas também compararam esses momentos em diferentes modelos de aparelhos de aférese, em que observaram diferença da contagem de leucócitos nos aparelhos utilizados. Apesar dessa diferença observada, o grupo de Beyan não atribuiu significância clínica a essa alteração, embora tenha avaliado somente uma única doação. Das máquinas de aférese estudadas por esse grupo, nenhuma foi a utilizada no presente trabalho (Trima Accel). Outro fator a ser considerado é em relação à metodologia dos grupos citados, pois a mesma foi diferente da metodologia que realizamos, uma vez consideram a contagem dos leucócitos logo após as doações realizadas. Um dado interessante observado por Rock e colaboradores (1992) (80) é que nos ciclos de doações estudadas, eles observaram aumento no número de linfócitos por volta da 3 a doação, sendo que este volta ao normal por volta da 5a doação. Esse fato pode ser um indício o papel homeostático do sistema imune a fim de manter a contagem dos linfócitos dentro da normalidade.

No presente trabalho, a comparação foi realizada entre grupos diferentes. Comparamos um grupo de doadores frequentes com um grupo de doadores de $1 \underline{a}$ vez. Nessa metodologia, não observamos diferenças significativas no numero total dos leucócitos em geral, e nem nas subpopulações analisadas (Linfócitos T e B, monócitos e células NK), considerando os dados obtidos do hemograma. Lewis e colaboradores (1997) (43), que utilizaram metodologia semelhante a aqui utilizada (comparação entre grupos) não encontrou diferenças significativas no número de leucócitos entre os grupos estudados (não doadores, doadores de sangue e doadores de plaquetas). Apesar das alterações encontradas (sendo significativas ou não) na contagem dos leucócitos totais, ou na contagem dos linfócitos, de forma mais específica, os grupos que abordaram o assunto afirmam que essas diferenças não causam modificações clínicas nesses doadores, sejam eles frequentes ou não $(43,53,58)$. A partir da contagem do hemograma, também não foi observada diferença no numero total de granulócitos. 
Comparando as populações mononucleares recuperadas do gradiente de densidade (Ficoll-Paque) observamos diferença estatística significante somente para células T CD8 ${ }^{+}$, em que os doadores frequentes apresentam o valor mediano de $0,24 \times 10^{6} \mathrm{cel} / \mathrm{mL}$ e os doadores de primeira vez $0,52 \times 10^{6} \mathrm{cel} / \mathrm{mL}$. Para essa mesma população, e para população de linfócitos T CD4, Hael e colaboradores (1983) (84) também observaram diminuição no número total de doadores frequentes. Tal diferença, para os linfócitos T CD8, não foi observada por Prior e colaboradores (1991) (85), que encontraram alterações para as outras sobpopulações estudadas (Linfócitos $T, T$ CD3, T CD4), diferenças tais que não foram observadas no presente estudo. No entanto, somente com base nesse resultado, não podemos afirmar que essa alteração tenha significados clínicos, para tanto, outros estudos são necessários.

No presente trabalho consideramos como doadores frequentes aqueles que realizaram no mínimo 6 doações/ano. No período de um ano, observou-se o máximo de 13 doações (dados não mostrados). Fazendo uma estimativa desse máximo de doações, com o valor mediano de células mononucleares retidas na $\operatorname{CLR}\left(1365 \times 10^{6}\right)$, o doador perderia aproximadamente $1,76 \times 10^{10}$ células mononucleares/ano, o que estaria abaixo do índice citado para possível leucopenia de $1 \times 10^{11}$ células em curto período de tempo $(53,86)$. Assim, a quantidade de leucócitos perdidas pelo doador no decorrer de um ano, não causaria danos clínicos no mesmo. Vale levar em consideração que esse caso de 13 doações/ano foi um caso isolado entre os doadores estudados, o valor mediano de doações foi de 4

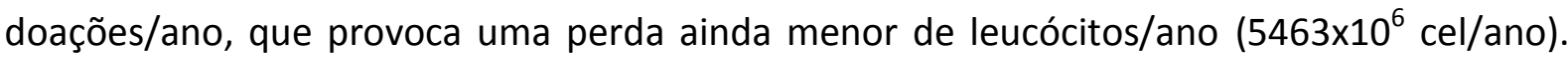
Além disso, linfopenia, caracterizada pela contagem de linfócitos abaixo de 1000/ $\mu$, não foi observado nos doadores frequentes.

Assim, para doadores frequentes de plaquetas estudados, notamos que não houve alteração no número de leucócitos, nem em suas subpopulações, quando comparados com os doadores de 1 a vez. No entanto, para maior compreensão das possíveis consequências de doações frequentes de plaquetas outros estudos ainda são necessários, levando em conta o histórico do doador, acompanhado os valores de leucócitos em cada doação e o tempo de reposição das células perdidas, bem como manifestações clínicas dessas alterações. Diariamente a medula óssea libera grande quantidade de células no sangue, que auxilia na manutenção da homeostase corpórea. Também é preciso levar em conta a frequência da doação. São permitidas até duas doações/semana, no entanto, o doador pode não ter essa disponibilidade, realizando as doações com intervalos maiores, fato muitas vezes observado 
por nós. Considerando o máximo de doação/ano (24), para alcançar essa frequência, seriam necessárias 2 doações/mês. Para determinar se essa frequência gera uma sobrecarga ao sistema hematopoiético ou não, são necessários mais estudos que abordem não somente as alterações no numero de leucócitos, mas também as manifestações clínicas no doador. Mas apesar disso, levando em conta os dados aqui apresentados, as doações frequentes de plaquetas parecem não causar alterações leucocitárias nos indivíduos, sendo assim uma prática segura para que doa e que faz grande diferença para quem recebe o produto dessas doações. 


\section{CONCLUSÕES}

Em relação à comparação das células mononucleares recuperadas da CLR e do sangue, foi possível observar que:

- A CLR fornece quantidade superior de células, quando comparadas com o mesmo volume de sangue;

- Apesar da maior concentração celular, as frequências das populações leucocitárias estudadas estão semelhantes à encontrada no sangue;

- As células recuperadas da CLR não apresentam alteração em seu estado de ativação, uma vez que os marcadores de ativação estão expressos de forma semelhante ao sangue;

- O processo de elutriação não altera as propriedades funcionais das células da CLR, uma vez que a capacidade proliferativa e de produção de citocinas estão similares à do sangue;

- As células da CLR não apresentam maior susceptibilidade a apoptose espontânea;

- A quantidade de CTH encontrada na CLR é superior àquela encontrada no sangue.

Em relação ao estudo de possíveis alterações leucocitárias devido a doações frequentes, foi possível observar que a concentração de leucócitos, e das subpopulações estudas, não sofrem alterações, quando comparadas com doadores de primeira vez. 


\section{REFERÊNCIAS ${ }^{1}$}

1. Delves PJ, Roitt IM. The immune system. First of two parts. N Engl J Med. 2000 Jul 6;343(1):37-49.

2. Moser M, Leo O. Key concepts in immunology. Vaccine. 2010 Aug 31;28 Suppl 3:C2-13.

3. Janeway CA, Jr., Medzhitov R. Innate immune recognition. Annu Rev Immunol. 2002;20:197216.

4. Auffray C, Sieweke MH, Geissmann F. Blood monocytes: development, heterogeneity, and relationship with dendritic cells. Annu Rev Immunol. 2009;27:669-92.

5. Ginhoux F, Jung S. Monocytes and macrophages: developmental pathways and tissue homeostasis. Nat Rev Immunol. 2014 May 23;14(6):392-404.

6. van Furth R, Cohn ZA, Hirsch JG, Humphrey JH, Spector WG, Langevoort HL. The mononuclear phagocyte system: a new classification of macrophages, monocytes, and their precursor cells. Bull World Health Organ. 1972;46(6):845-52.

7. Geissmann F, Manz MG, Jung S, Sieweke MH, Merad M, Ley K. Development of monocytes, macrophages, and dendritic cells. Science. 2010 Feb 5;327(5966):656-61.

8. Cruvinel Wde M, Mesquita D, Jr., Araujo JA, Catelan TT, de Souza AW, da Silva NP, et al. Immune system - part I. Fundamentals of innate immunity with emphasis on molecular and cellular mechanisms of inflammatory response. Rev Bras Reumatol. 2010 Jul-Aug;50(4):434-61.

9. Caligiuri MA. Human natural killer cells. Blood. 2008 Aug 1;112(3):461-9.

10. Whiteside TL, Herberman RB. Role of human natural killer cells in health and disease. Clin Diagn Lab Immunol. 1994 Mar;1(2):125-33.

11. Hoebe $\mathrm{K}$, Janssen E, Beutler B. The interface between innate and adaptive immunity. Nat Immunol. 2004 Oct;5(10):971-4.

12. Hallett WH, Murphy WJ. Natural killer cells: biology and clinical use in cancer therapy. Cell Mol Immunol. 2004 Feb;1(1):12-21.

13. Surh CD, Sprent J. Homeostasis of naive and memory T cells. Immunity. 2008 Dec 19;29(6):848-62.

14. Boyman O, Purton JF, Surh CD, Sprent J. Cytokines and T-cell homeostasis. Curr Opin Immunol. 2007 Jun;19(3):320-6.

15. Chaplin DD. Overview of the immune response. J Allergy Clin Immunol. 2010 Feb;125(2 Suppl 2):S3-23.

\footnotetext{
${ }^{1}$ De acordo com:

International Committee of Medical Journal Editors. [Internet]. Uniform requirements for manuscripts submitted to Biomedical Journal: sample references. [updated $2011 \mathrm{Jul} 15$ ]. Available from:

http://www.icmje.org
} 
16. Harwood NE, Batista FD. Early events in B cell activation. Annu Rev Immunol. 2010;28:185210.

17. Nagafuchi S. The role of B cells in regulating the magnitude of immune response. Microbiol Immunol. 2010 Aug;54(8):487-90.

18. Lund FE. Cytokine-producing B lymphocytes-key regulators of immunity. Curr Opin Immunol. 2008 Jun;20(3):332-8.

19. Appay V, van Lier RA, Sallusto F, Roederer M. Phenotype and function of human T lymphocyte subsets: consensus and issues. Cytometry A. 2008 Nov;73(11):975-83.

20. Trowbridge IS, Thomas ML. CD45: an emerging role as a protein tyrosine phosphatase required for lymphocyte activation and development. Annu Rev Immunol. 1994;12:85-116.

21. Arlettaz L, Barbey C, Dumont-Girard F, Helg C, Chapuis B, Roux E, et al. CD45 isoform phenotypes of human T cells: CD4(+)CD45RA(-)RO(+) memory $T$ cells re-acquire CD45RA without losing CD45RO. Eur J Immunol. 1999 Dec;29(12):3987-94.

22. Faint JM, Annels NE, Curnow SJ, Shields $P$, Pilling $D$, Hislop AD, et al. Memory $T$ cells constitute a subset of the human CD8+CD45RA+ pool with distinct phenotypic and migratory characteristics. J Immunol. 2001 Jul 1;167(1):212-20.

23. Beverley PC, Daser A, Michie CA, Wallace DL. Functional subsets of $T$ cells defined by isoforms of CD45. Biochem Soc Trans. 1992 Feb;20(1):184-7.

24. Mackay CR. Dual personality of memory T cells. Nature. 1999 Oct 14;401(6754):659-60.

25. Sallusto F, Lenig D, Forster R, Lipp M, Lanzavecchia A. Two subsets of memory T lymphocytes with distinct homing potentials and effector functions. Nature. 1999 Oct 14;401(6754):708-12.

26. Hamann D, Baars PA, Rep MH, Hooibrink B, Kerkhof-Garde SR, Klein MR, et al. Phenotypic and functional separation of memory and effector human CD8+ T cells. J Exp Med. 1997 Nov 3;186(9):1407-18.

27. Appay V, Dunbar PR, Callan M, Klenerman P, Gillespie GM, Papagno L, et al. Memory CD8+ T cells vary in differentiation phenotype in different persistent virus infections. Nat Med. 2002 Apr;8(4):379-85.

28. Wynn TA, Chawla A, Pollard JW. Macrophage biology in development, homeostasis and disease. Nature. 2013 Apr 25;496(7446):445-55.

29. Boyd AL, Bhatia M. Bone marrow localization and functional properties of human hematopoietic stem cells. Curr Opin Hematol. 2014 Jul;21(4):249-55.

30. Hoffbrand AV, Moss PAH, Pettit JE, editors. Fundamentos em Hematologia. 5a ed. Porto Alegre: Artmed; 2008.

31. Oliveira MRA, editor. Hematologia básica. 3. ed: Luana; 2003.

32. Lorenzi TF, editor. Manual de hematologia. Propedeutica e Clínica. 4a ed. Rio de Janeiro: Guanabara Koogan; 2006. 
33. Abdelhay ESFW, Paraguaçú-Braga FH, Binato R, Bouzas LFS. Células-tronco de origem hematopoética: expansão e perspectivas de uso terapêutico. Rev Bras Hematol Hemoter. 2009;31(Supl. 1):2-8.

34. Wognum AW, Eaves AC, Thomas TE. Identification and isolation of hematopoietic stem cells. Arch Med Res. 2003 Nov-Dec;34(6):461-75.

35. Organização Mundial de Saúde. "Blood Safety" [database on the Internet]. 2011.

36. Ieromnimon V, Kruger J, Schmidt R, Sehrbundt M. Effect of blood donations on the profile of lymphocytic cells. Vox Sang. 1981 Sep;41(3):165-71.

37. AABB. American Association of Blood Banks. "“Blood FAQ”. 2012 [cited 2012].

38. Shapiro MJ. To filter blood or universal leukoreduction: what is the answer? Crit Care. 2004;8 Suppl 2:S27-30.

39. Sutherland DR, Keeney M, Gratama JW. Enumeration of CD34+ hematopoietic stem and progenitor cells. Curr Protoc Cytom. 2003 Aug;Chapter 6:Unit 64.

40. Lazarus EF, Browning J, Norman J, Oblitas J, Leitman SF. Sustained decreases in platelet count associated with multiple, regular plateletpheresis donations. Transfusion. 2001 Jun;41(6):756-61.

41. Burgstaler EA. Blood component collection by apheresis. J Clin Apher. 2006 Jul;21(2):142-51.

42. Ward DM. Conventional apheresis therapies: a review. J Clin Apher. 2011;26(5):230-8.

43. Lewis SL, Kutvirt SG, Bonner PN, Simon TL. Effect of long-term platelet donation on lymphocyte subsets and plasma protein concentrations. Transfus Sci. 1997 Jun;18(2):205-13.

44. Braine HG, Elfenbein GJ, Mellits ED. Peripheral blood lymphocyte numbers, lymphocyte proliferative responses in vitro, and serum immunoglobulins in regular hemapheresis donors. J Clin Apher. 1985;2(3):213-8.

45. Dietz AB, Bulur PA, Emery RL, Winters JL, Epps DE, Zubair AC, et al. A novel source of viable peripheral blood mononuclear cells from leukoreduction system chambers. Transfusion. 2006 Dec;46(12):2083-9.

46. Neron S, Thibault L, Dussault N, Cote G, Ducas E, Pineault N, et al. Characterization of mononuclear cells remaining in the leukoreduction system chambers of apheresis instruments after routine platelet collection: a new source of viable human blood cells. Transfusion. 2007 Jun;47(6):1042-9.

47. Peytour Y, Guitart A, Villacreces A, Chevaleyre J, Lacombe F, Ivanovic Z, et al. Obtaining of CD34+ cells from healthy blood donors: development of a rapid and efficient procedure using leukoreduction filters. Transfusion. 2010 Oct;50(10):2152-7.

48. Cook MA, Jobson SE, Atkinson DC, Lowe DP, Farmer SL, Alvi-Ali WJ, et al. Used leucodepletion filters as a source of large quantities of DNA suitable for the study of genetic variations in human populations. Transfus Med. 2003 Apr;13(2):77-81.

49. Longley RE, Stewart D. Recovery of functional human lymphocytes from Leukotrap filters. J Immunol Methods. 1989 Jul 6;121(1):33-8. 
50. Teleron AA, Carlson B, Young PP. Blood donor white blood cell reduction filters as a source of human peripheral blood-derived endothelial progenitor cells. Transfusion. 2005 Jan;45(1):21-5.

51. Izquierdo N, Naranjo M, Fernández MA, Cos J, Massuet L, Martínez-Picado J, et al. Leukocyte Reduction Filters: an alternative source of Peripheral Blood Mononuclear Cells. Inmunología. 2003;22(3):255-62.

52. Jeremiah ZA, Umoh RE, Adias TC. Subclinical leukopenia in a cross section of Nigerian blood donors. J Blood Med. 2011;2:79-85.

53. Strauss RG. Risks of clinically significant thrombocytopenia and/or lymphocytopenia in donors after multiple plateletpheresis collections. Transfusion. 2008 Jul;48(7):1274-8.

54. Richa E, Krueger P, Burgstaler EA, Bryant SC, Winters JL. The effect of double- and tripleapheresis platelet product donation on apheresis donor platelet and white blood cell counts. Transfusion. 2008 Jul;48(7):1325-32.

55. Steininger PA, Smith R, Geier C, Zimmermann R, Eckstein R, Strasser EF. Leukapheresis in non-cytokine-stimulated donors with a new apheresis system: first-time collection results and evaluation of subsequent cryopreservation. Transfusion. 2013 Apr;53(4):747-56.

56. Beutler E, Lichtman MA, Coller BS, Kipps TJ, U. S, editors. Williams Hematology. 6th ed. New Yourk: McGraw Hill; 2001.

57. Koepke JA, Parks WM, Goeken JA, Klee GG, Strauss RG. The safety of weekly plateletpheresis: effect on the donors' lymphocyte population. Transfusion. 1981 Jan-Feb;21(1):59-63.

58. Katz L, Palmer K, McDonnell E, Kabat A. Frequent plateletpheresis does not clinically significantly decrease platelet counts in donors. Transfusion. 2007 Sep;47(9):1601-6.

59. Matsui Y, Martin-Alosco S, Doenges E, Christenson L, Shapiro HM, Yunis EJ, et al. Effects of frequent and sustained plateletapheresis on peripheral blood mononuclear cell populations and lymphocyte functions of normal volunteer donors. Transfusion. 1986 Sep-Oct;26(5):446-52.

60. Robbins G, Petersen CV, Brozovic B. Lymphocytopenia in donors undergoing regular platelet apheresis with cell separators. Clin Lab Haematol. 1985;7(3):225-30.

61. Malek TR. The biology of interleukin-2. Annu Rev Immunol. 2008;26:453-79.

62. Ebner S, Neyer S, Hofer S, Nussbaumer W, Romani N, Heufler C. Generation of large numbers of human dendritic cells from whole blood passaged through leukocyte removal filters: an alternative to standard buffy coats. J Immunol Methods. 2001 Jun 1;252(1-2):93-104.

63. Strasser EF, Weidinger T, Zimmermann R, Ringwald J, Eckstein R. Recovery of white blood cells and platelets from leukoreduction system chambers of Trima Accel and COBE Spectra plateletpheresis devices. Transfusion. 2007 Oct;47(10):1943-4; author reply 4-5.

64. Weidinger TM, Keller AK, Weiss D, Zimmermann R, Eckstein R, Strasser EF. Peripheral blood mononuclear cells obtained from leukoreduction system chambers show better viability than those from leukapheresis. Transfusion. 2011 Sep;51(9):2047-9. 
65. Pfeiffer IA, Zinser E, Strasser E, Stein MF, Dorrie J, Schaft N, et al. Leukoreduction system chambers are an efficient, valid, and economic source of functional monocyte-derived dendritic cells and lymphocytes. Immunobiology. 2013 Nov;218(11):1392-401.

66. Neron S, Dussault N, Racine C. Whole-blood leukoreduction filters are a source for cryopreserved cells for phenotypic and functional investigations on peripheral blood lymphocytes. Transfusion. 2006 Apr;46(4):537-44.

67. Meyer TP, Zehnter I, Hofmann B, Zaisserer J, Burkhart J, Rapp S, et al. Filter Buffy Coats (FBC): a source of peripheral blood leukocytes recovered from leukocyte depletion filters. J Immunol Methods. 2005 Dec 20;307(1-2):150-66.

68. Tiscornia I, Sanchez-Martins V, Hernandez A, Bollati-Fogolin M. Human monocyte-derived dendritic cells from leukoreduction system chambers after plateletpheresis are functional in an in vitro co-culture assay with intestinal epithelial cells. J Immunol Methods. 2012 Oct 31;384(1-2):16470.

69. Itoua Maiga R, Lemieux J, Roy A, Simard C, Neron S. Flow cytometry assessment of in vitro generated CD138+ human plasma cells. Biomed Res Int. 2014;2014:536482.

70. Freitas AA, Rocha B. Population biology of lymphocytes: the flight for survival. Annu Rev Immunol. 2000;18:83-111.

71. Sprent J, Cho JH, Boyman O, Surh CD. T cell homeostasis. Immunol Cell Biol. 2008 MayJun;86(4):312-9.

72. Clement LT. Isoforms of the CD45 common leukocyte antigen family: markers for human Tcell differentiation. J Clin Immunol. 1992 Jan;12(1):1-10.

73. Cossarizza A, Ortolani C, Paganelli R, Barbieri D, Monti D, Sansoni P, et al. CD45 isoforms expression on $\mathrm{CD} 4+$ and $\mathrm{CD} 8+\mathrm{T}$ cells throughout life, from newborns to centenarians: implications for T cell memory. Mech Ageing Dev. 1996 Mar 29;86(3):173-95.

74. De Rosa SC, Herzenberg LA, Roederer M. 11-color, 13-parameter flow cytometry: identification of human naive T cells by phenotype, function, and T-cell receptor diversity. Nat Med. $2001 \mathrm{Feb} ; 7(2): 245-8$.

75. Amer J, Frankenburg S, Fibach E. Apheresis induces oxidative stress in blood cells. Ther Apher Dial. 2010 Apr;14(2):166-71.

76. Strasser EF, Weidinger T, Weiss DR, Strobel J, Zimmermann R, Eckstein R. Storage induced apoptosis of peripheral blood mononuclear cells obtained from leucoreduction system chambers. Vox Sang. 2011 Aug;101(2):106-11.

77. Peytour Y, Villacreces A, Chevaleyre J, Ivanovic Z, Praloran V. Discarded leukoreduction filters: a new source of stem cells for research, cell engineering and therapy? Stem Cell Res. 2013 Sep;11(2):736-42.

78. Jansen J, Hanks S, Thompson JM, Dugan MJ, Akard LP. Transplantation of hematopoietic stem cells from the peripheral blood. J Cell Mol Med. 2005 Jan-Mar;9(1):37-50. 
79. Ivanovic Z, Duchez P, Morgan DA, Hermitte F, Lafarge X, Chevaleyre J, et al. Whole-blood leuko-depletion filters as a source of $C D 34+$ progenitors potentially usable in cell therapy. Transfusion. 2006 Jan;46(1):118-25.

80. Rock G, Tittley P, Sternbach M, Buskard N, Schroeder M. Repeat plateletpheresis: the effects on the donor and the yield. Vox Sang. 1992;63(2):102-6.

81. Beyan C, Cetin T, Kaptan K, Nevruz O. Effect of plateletpheresis on complete blood count values using three different cell separator systems in healthy donors. Transfus Apher Sci. 2003 Aug;29(1):45-7.

82. Strauss RG. Effects on donors of repeated leukocyte losses during plateletpheresis. J Clin Apher. 1994;9(2):130-4.

83. Das; SS, Chaudhary; R, Verma; SK, Ojha; S, Khetan D. Pre- and post- donation haematological values in healthy donors undergoing plateletpheresis with five different systems. Blood Transfusion. [Original Article]. 2009;7:188-92.

84. Heal JM, Horan PK, Schmitt TC, Bailey G, Nusbacher J. Long-term follow-up of donors cytapheresed more than 50 times. Vox Sang. 1983;45(1):14-24.

85. Prior CR, Coghlan PJ, Hall JM, Jacobs P. In vitro study of immunologic changes in long-term cytapheresis donors. J Clin Apher. 1991;6(2):69-76.

86. Winters JL. Complications of donor apheresis. J Clin Apher. 2006 Jul;21(2):132-41. 
APÊNDICE A - Termo de consentimento Livre Esclarecido

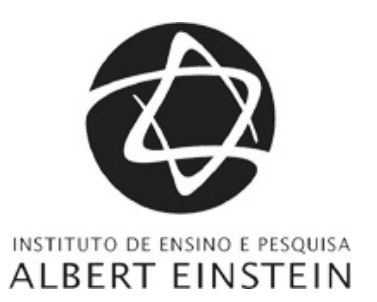

\section{Termo de Consentimento Livre e Esclarecido}

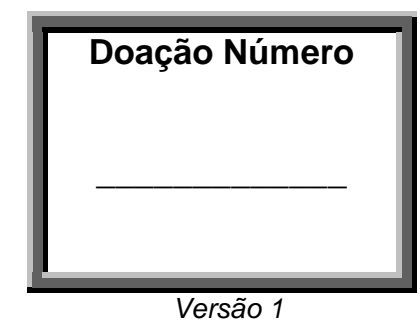

\section{Termo de Consentimento Livre e Esclarecido}

Prezado (a) doador (a), o (a) Sr. (a) está sendo convidado (a) a participar, como voluntário (a), no projeto de pesquisa intitulado "Análise das populações leucocitárias em doadores frequentes de plaquetas e em câmara de leuco-redução".

A doação de sangue e plaquetas é um ato voluntário sendo considerado um procedimento seguro para os doadores. No processo de obtenção dessas plaquetas, é utilizado um tipo de "filtro", denominado câmara de leuco-redução, no qual uma pequena quantidade de sangue fica retida sendo descartada junto com a câmara, ao final do processo. Este sangue retido na câmara é rico em células sanguíneas denominadas leucócitos que não serão utilizados em procedimentos transfusionais, mas podem ser utilizados para pesquisa científica.

Este projeto tem como objetivo avaliar se as doações repetidas de plaquetas causam alguma modificação na composição dos diferentes tipos de leucócitos existentes no sangue de indivíduos que doam plaquetas frequentemente, em comparação com indivíduos que nunca doaram ou que estão fazendo a doação pela primeira vez. Outro objetivo é verificar se a distribuição das células na câmara de leuco-redução é a mesma encontrada no sangue.

Para realizar o projeto, pedimos sua autorização para utilização das células contidas no filtro de leuco-redução, para a retirada de uma pequena quantidade (10 a $20 \mathrm{ml}$ ) de sangue venoso, obtidos sem qualquer interferência no procedimento padrão da doação e sem apresentar qualquer ônus ao doador, e permissão para acessar os resultados dos exames de rotina realizados em virtude das suas doações.

Durante todo o período da pesquisa você tem o direito de tirar qualquer dúvida ou pedir qualquer outro esclarecimento, bem como retirar sua participação a qualquer momento, sem nenhum tipo de prejuízo ou retaliação.

Não será cobrado nada e não haverá gastos nem riscos na sua participação neste estudo, portanto não estão previstos ressarcimentos ou indenizações. Não haverá benefícios imediatos na sua participação, mas os resultados contribuirão para o 
melhor entendimento dos efeitos de seguidas doações de plaquetas sobre os leucócitos. Seu nome não será utilizado em qualquer fase da pesquisa, o que garante seu anonimato.

As informações desta pesquisa serão confidencias, e serão divulgadas apenas em eventos ou publicações científicas, não havendo identificação dos voluntários, a não ser entre os responsáveis pelo estudo, sendo assegurado o sigilo sobre sua participação (confidencialidade).

Em caso de dúvidas e outros esclarecimentos sobre esta pesquisa você poderá entrar em contato com o Comitê de Ética em Pesquisa no tel.2151.3729 (e-mail: cep@einstein.br) e ou a equipe responsável pelo projeto (vide abaixo):

\section{Equipe Responsável pelo Projeto:}

Dr. Luiz Roberto Sardinha (Coordenador) F. 2151-3512

Andressa de Oliveira Dias Borges

Dra. Araci Massami Sakashita

Dra. Anna Carla Renata Krepel Goldberg

Após a leitura deste documento, acredito estar suficientemente informado, ficando claro para mim que minha participação é voluntária e que posso retirar este consentimento a qualquer momento sem penalidades ou perda de qualquer benefício. Estou ciente também dos objetivos da pesquisa, e da garantia de confidencialidade e esclarecimentos sempre que desejar. Diante do exposto expresso minha concordância de espontânea vontade em participar deste estudo.

Nome doador:

Assinatura doador: Data:

Testemunha (se necessário):

Assinatura da testemunha:

Data:

Nome (Eq. Responsável):

Assinatura (Eq. Responsável): Data: 


\section{APÊNDICE B - Análises de correlação}

Figura B1 - Diagramas de dispersão do rendimento celular da CLR com informações individuais e da coleta.

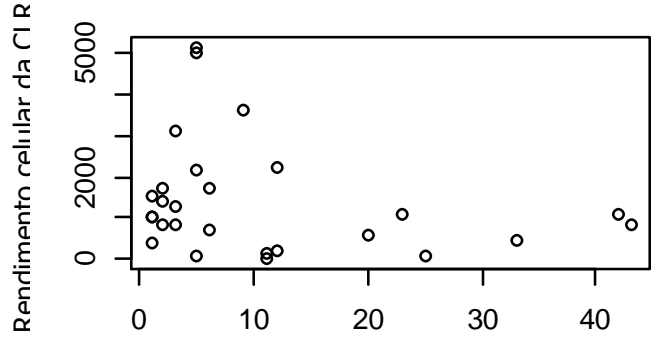

Número de doações

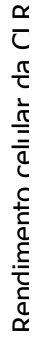

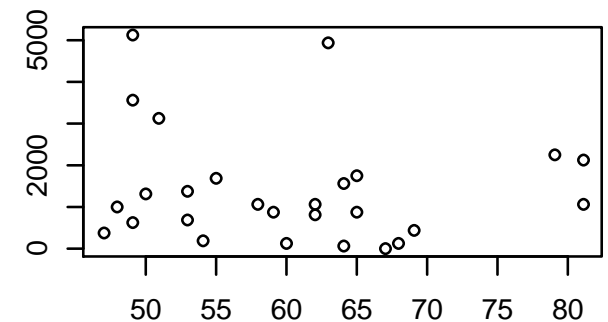

Tempo de doação

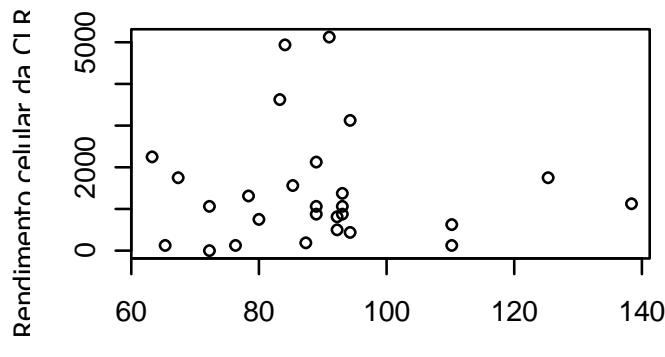

Peso

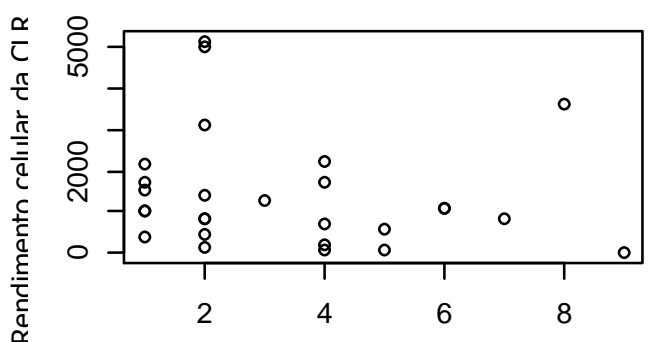

Número de doações no último ano
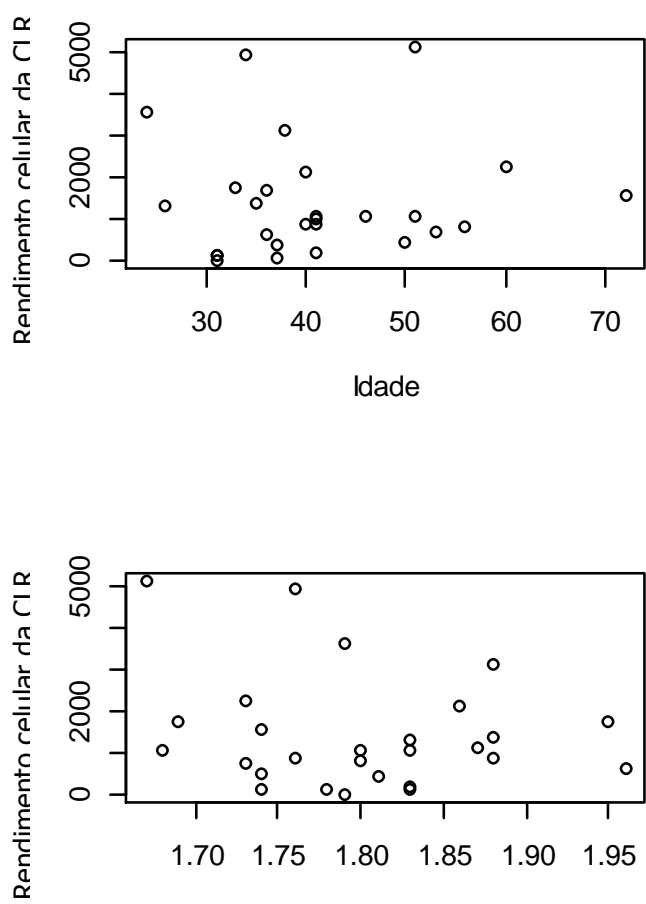

Altura

\begin{tabular}{ccc}
\hline Variável & rho & p \\
\hline Altura $(\mathrm{m})$ & $-0,057$ & 0,779 \\
Idade (anos) & 0,091 & 0,653 \\
Número de doações no último ano & $-0,240$ & 0,227 \\
Número de doações & $-0,260$ & 0,190 \\
Peso (kg) & 0,031 & 0,876 \\
Tempo de doação (min) & $-0,090$ & 0,654 \\
\hline
\end{tabular}

Correlação inexistente entre o rendimento da CLR e as variáveis observadas.

Teste de correlação de Sperman; rho: coeficiente de correlação de Spearman; $p$ associado ao teste de não nulidade do coeficiente de correlação de Spearman. CLR = Câmara de Leucorredução 
Figura B2 - Diagramas de dispersão do rendimento celular do pião com informações sanguíneas.
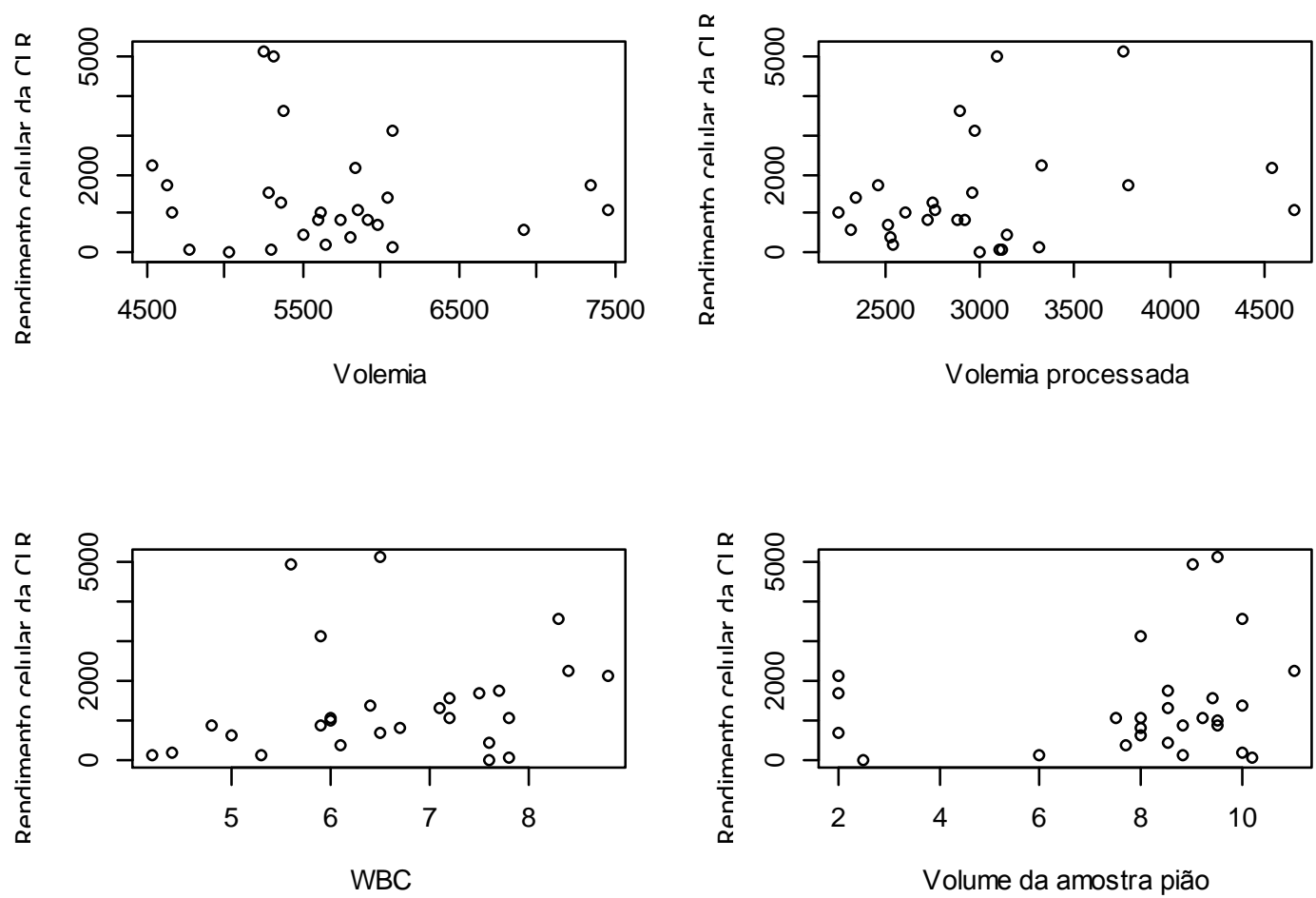

\begin{tabular}{ccc}
\hline Variável & rho & $\mathbf{p}$ \\
\hline Volemia & $-0,060$ & 0,766 \\
Volemia processada & 0,209 & 0,295 \\
Volume da amostra pião & 0,173 & 0,389 \\
WBC & 0,314 & 0,111 \\
\hline
\end{tabular}

Correlação inexistente entre o rendimento da CLR e as variáveis observadas.

Teste de correlação de Sperman; rho: coeficiente de correlação de Spearman; $p$ associado ao teste de não nulidade do coeficiente de correlação de Spearman. CLR = Câmara de Leucorredução. 
Figura B3 - Rendimento celular da CLR por grupo de produto coletado (plaqueta dupla ou simples).

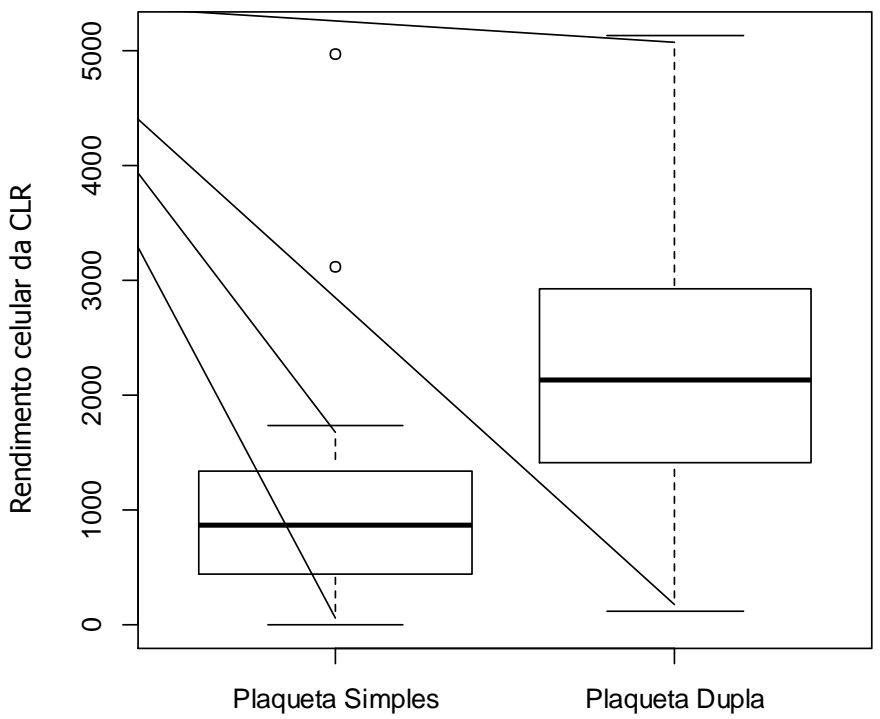

Há associação entre o rendimento celular do pião e o produto doado na coleta $(p=0,026)$. 0 rendimento é maior quando se obtém, na coleta, plaquetas duplas. Teste de Mann-Whitney. 
APÊNDICE C - Comparação do rendimento celular obtidos de amostras de sangue e da Câmara de Leucorredução de mesmo doador.

\begin{tabular}{ccc}
\hline \multirow{2}{*}{ Doador } & \multicolumn{2}{c}{ Rendimento Celular/mL $\left(\mathbf{x 1 0 ^ { 6 } )}\right.$} \\
\cline { 2 - 3 } & Sangue & CLR \\
\hline 1 & 0,98 & 5,52 \\
2 & 0,98 & 52,95 \\
3 & 0,68 & 54,75 \\
4 & 1,16 & 76,5 \\
5 & 1,12 & 132,45 \\
6 & 0,93 & 11,325 \\
7 & 0,99 & 98,85 \\
8 & 1,33 & 101,4 \\
9 & 3,34 & 164,7 \\
10 & 0,65 & 18,8 \\
11 & 0,93 & 1,725 \\
12 & 2,42 & 146,55 \\
13 & 1,3 & 153,9 \\
\hline Mediana & 1,0 & 76,5 \\
Intervalo Interquartil & 0,$93 ; 1,31$ & 15,$06 ; 139,5$ \\
\hline
\end{tabular}

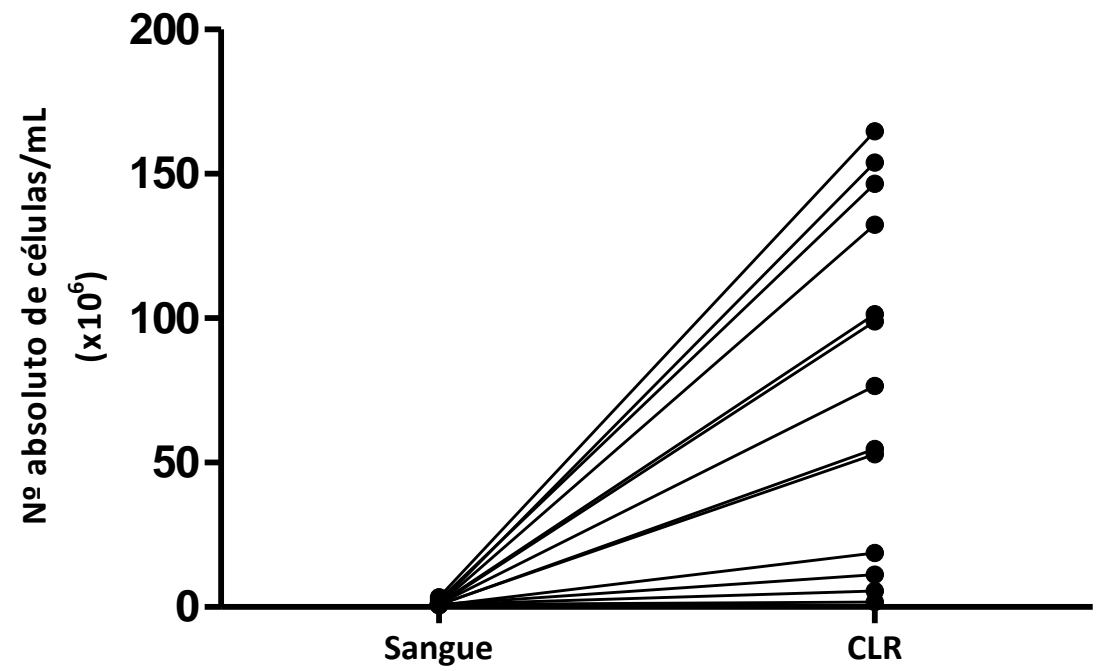

n = 13; CLR = Câmara de Leucorredução. 